\title{
Living in times of war: waste of $c .1600$ from two garderobe chutes in the castle of Middelburg-in-Flanders (Belgium)
}

\author{
By WIM DE CLERCQ, DANIELLE CALUWÉ, BRIGITTE COOREMANS, FRANS DE BUYSER, \\ KOEN DE GROOTE, KOEN DEFORCE, ANTON ERVYNCK, AN LENTACKER, STEVEN \\ MORTIER, PEDRO PYPE, STEPHANE VANDENBERGHE, WIM VAN NEER and HILDE \\ WOUTERS
}

\begin{abstract}
SUMMARY: The material remains and environmental data recovered during a rescue excavation in 2002-03 in the castle of the new town of Middelburg-in-Flanders throw light on the site, region and landscape in wartime. The paper discusses the historical context at the turn of the 16th century, the excavation of the castle, the taphonomy of the chutes, the analysis of the artefacts and ecological data recovered from two garderobe chutes in the upper court, and concludes with a synthesis focussing on the interpretation of the excavated record in the historically attested natural and socio-economic disruption caused by the Spanish-Dutch War.
\end{abstract}

\section{INTRODUCTION}

The contents of two large garderobe chutes were recovered during a rescue excavation in 2002-03 on the site of the castle of Middelburg-in-Flanders (Maldegem, East Flanders province, Belgium), now a small village on the border with the Netherlands, $15 \mathrm{~km}$ west of Bruges. The town and its castle were founded during the mid-15th century as an expression of the elite status of the owner, Pieter Bladelin. The town continued to prosper in the 16 th century under the rule of the d'Oignies family. By 1578 the town and castle had lost their high status. Middelburg and other towns along the coast and in the Scheldt estuary like Ostend, Aardenburg, Sluis, Hulst and Antwerp, became an important arena in the Eighty Years War in which Dutch Protestant and Spanish Catholic armies fought in what was to become the border between the present-day countries of Belgium and the Netherlands. By the beginning of the 18 th century, the castle had fallen into ruins and the town shrunk to a small village.
As a result the 15th-century street scheme remains unchanged and parts of the town's 16thand 17th-century defences are still visible. The archaeological record lies untouched under the modern village. Because few archaeologists were aware of this new town, no interest was shown in excavating the many remains destroyed by building in the 1990s. In 2001, a team of young archaeologists started an excavation to rescue the castle of the town's founder from destruction by a new housing estate. ${ }^{1}$ Because Middelburg is one of the few new towns in Flanders and because of its exceptional archaeological preservation and scientific value, in 2003 it became the first archaeological monument in Flanders to be legally protected by the Flemish Government.

THE NEW TOWN OF MIDDELBURG-IN-FLANDERS ${ }^{2}$

\section{By WIM DE CLERCQ}

The castle and new town of Middelburg-inFlanders ${ }^{3}$ were founded in 1448 by Pieter Bladelin, 
treasurer and councillor of the Dukes of Burgundy, Philip the Good and his son Charles the Bold. According to the Burgundian chronicler Georges Chastelain, Bladelin was 'riche de biens de fortune outre mesure' ${ }^{4} \mathrm{He}$ also became the treasurer of the illustrious knightly Order of the Golden Fleece. By founding his new town near the important centres of Bruges, Damme, Sluis and Aardenburg (Fig. 1), Bladelin expressed his economic and political power and desire for noble status. This urge was also reflected in the Middelburg Altarpiece or Bladelin Triptych, one of Rogier Van der Weyden's most famous paintings. ${ }^{5}$

In the later 16th century Middelburg was frequently seized and occupied by the Spanish and Dutch armies, who destroyed the town and flooded its arable territory by cutting the dykes at Sluis. These disastrous events are chronicled in the exceptional diary written between 1579 and 1583 by Adolf Dhooghe, the Catholic priest of Middelburg. ${ }^{6}$ Other sources of information are the town accounts ${ }^{7}$ and the later interrogation of eyewitnesses to the events around $1600 .^{8}$

\section{THE MILITARY OCCUPATION OF THE CASTLE IN THE LATE 16TH CENTUR Y9}

Although the castle had always had a small garrison, its militarization began in 1578 when the Franc of Bruges ordered Captain Jacob the Graeve and 50 soldiers to be quartered there. The town accounts for 1578 mention 'work to be undertaken on the town defences', showing an awareness of impending trouble. On 20 August 1578, Protestant rebels looted the convent of the Poor Clares and less than a year later on 14 June 1579, a large group of them managed for the first time to conquer and plunder the town and castle. Apparently, the presence of soldiers led by Upper-Captain Tielcke and later of Captain Van Rijswijck and his men did not deter the Protestants from attacking the town. As the attempts by Philip d'Oignies, the lord of Middelburg, to negotiate were unsuccessful, the rebels entered the castle, looted his possessions and those of the nuns who had taken refuge there. From then until about 1607 the lords of Middelburg no longer lived there, leaving its fate

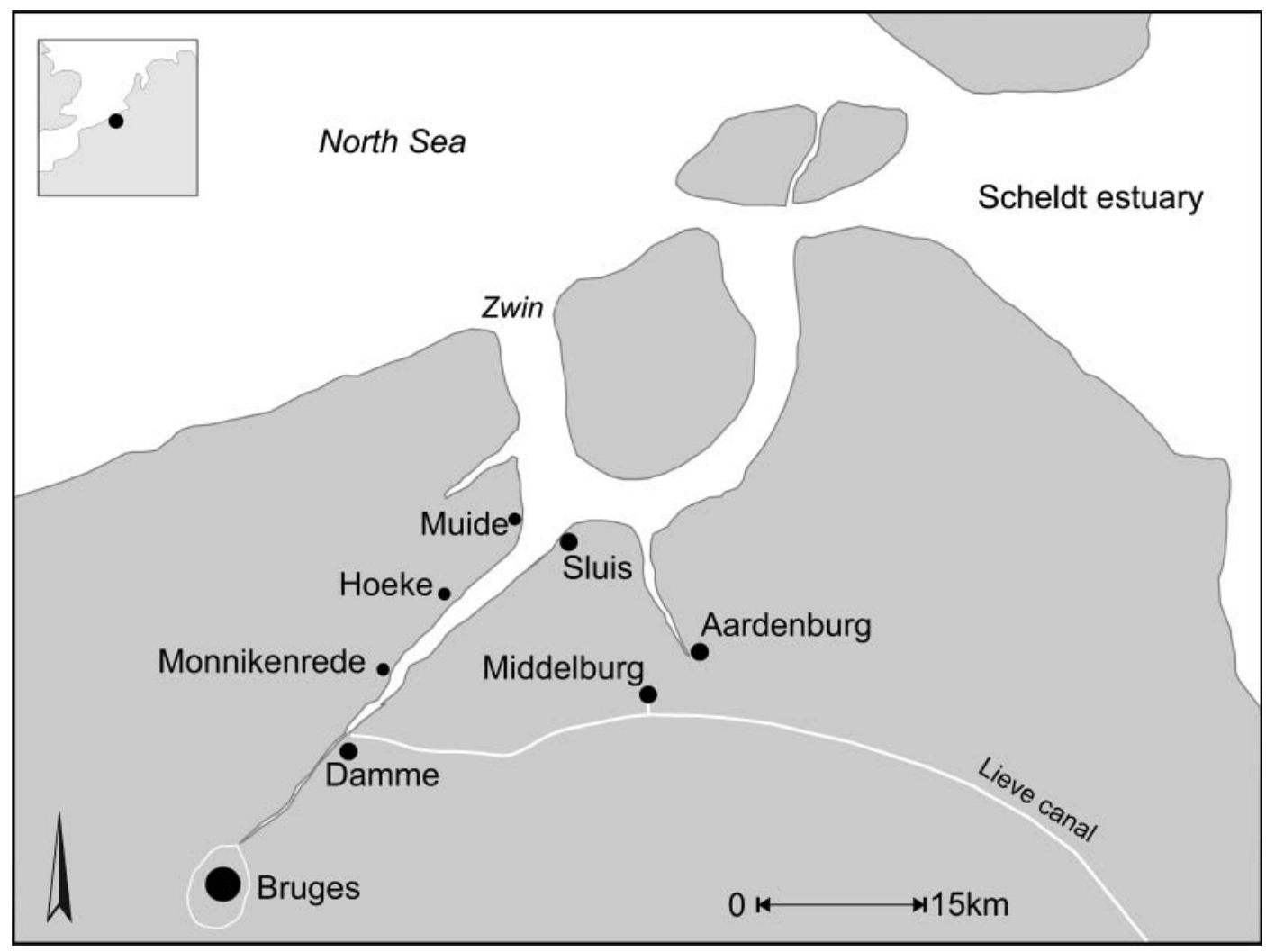

FIG. 1

Geographical setting of Middelburg at the time of its foundation in 1448 . 
to the military. The town accounts record a series of commanders quartered in the castle between 1579 and 1583. During the rebel captain Joos de Hondt's occupation until 1 October 1579, wheat was requisitioned 'for the castle'. The Scottish soldiers who replaced him did not prevent the church from being looted on 27 March and 12 June 1581. They were followed by Captain Ouweel and his soldiers in November. In that month, the Prince of Orange and his army called at Middelburg. In 1581-82, the French colonel Rochepot and later in 1582-83, captains Homes and Symon and Colonel Charles Thierlonghe occupied the castle. From April to October colonels Van Lokeren, Detraille and the Englishman 'Morghen' were encamped 'and in the same season his Majesty's army'. On 13 October 1583 the English soldiers quartered in the castle received the order from their headquarters in Sluis to burn the town to prevent it from falling into Spanish hands. Within hours, the town was almost completely destroyed by fire; only six houses remained intact. The town accounts record significant damage as well to Middelburg's countryside in 1583-85: 'most of the land, hedges and woods have been drowned by salt water from breaching the dykes ... nearby the besieged town and castle of Sluis. ${ }^{10}$

When the Spanish commander Alexander Farnese took the town on 18 October 1583, he encountered almost no resistance and found the town in ruins. A Spanish army unit led by Captain Staercke remained in the castle, threatening the already impoverished inhabitants and the nearby countryside. In order to please the occupying force, the people of Middelburg offered salmon and a bow to the commander and game birds for the wedding of the daughter of his superior, the governor Simeon at Damme. In 1584, even the nearby town of Aardenburg sent four barrels of beer to Staercke's soldiers. In 1590, after more than ten years without a lord, Middelburg received a new noble leader: Philip de Merode, who had married one of Philip d'Oignies's heirs. Thereafter the political and military context was more favourable for the region. The only attack recorded in the last decade of the century was on 10 September 1590 . The new lord did not live in Middelburg and his castle was occupied by several poorer families, including the bailiff Provoost and his wife, who was accused of sorcery in 1596 . The other families were farmers. In 1598 even an innkeeper named Jan De Lille is mentioned in the town accounts. Only seven soldiers were quartered there between 1598 and 1600 . The castle apparently lost its elite and military functions. Presumably, that decade was a poor though relatively safe and stable time for Middelburg.
However, a second disastrous period started in 1604. Maurice of Nassau took the town on 12 May, encountering virtually no opposition; he only found some farmers in the castle, as most of the people of Middelburg had sought refuge outside. The town was again looted and destroyed. Shortly afterwards, in an attempt to relieve the siege of the Spanish commander Serrano and his troops in Sluis, Ambrosio Spinola occupied Middelburg briefly from 27 July to 1 August, when he was forced by artillery to withdraw to Ostend. From 1604 to 1608 Lord Thoricourt, the AdjutantGeneral of the Council of War, was stationed in the castle with his Irish and German troops. The witnesses in the 1632 court proceedings testified that his army numbered between 3,000 and 4,000 soldiers, all encamped in the town of Middelburg. ${ }^{11}$ In 1607 the aldermen of the nearby town of Damme described the remains of the town and 'namely the castle' as 'the most beautiful, biggest and most important fief of the Franc of Bruges ... It is ruined [by successive armies, garrisons and wars] and ready to be totally dismantled since there is almost no stone standing upon another'. The trees and woods had been cut or set alight, and a large part of its territory 'lies level with the sea, very sad and lamentable to see'. ${ }^{12}$ This was confirmed by almost all the witnesses in 1632, who also stated that some of the wood had been used by the soldiers to build barracks and that the stables had sheltered the soldiers' own cattle. ${ }^{13}$

The detailed drawing by Floris Balthasar, a member of Maurice of Nassau's retinue during his campaign in the region in May 1604, still shows Middelburg with its old-fashioned 15thcentury moat. ${ }^{14}$ However, the historian Grammaye recorded in 1612 that during the Lordship of Philip de Merode's ramparts and ditches had given the town a new look..$^{15} \mathrm{~A}$ draft plan shows that a new defensive system designed to cope with artillery warfare was constructed in 1610 or shortly afterwards. ${ }^{16}$

When in 1609 the Twelve Year Truce began, Philip de Merode continued the reconstruction and in 1621 he received an Act of Neutrality for the town. In 1648 the Munster Peace was agreed and Middelburg became a border town in Catholic territory. The town was again contested at the turn of 17th century when the Dutch and French fought the Wars of Spanish Succession. An accurate plan made in 1702 by the French military engineer Senneton de Chermont shows that only part of the original castle was still preserved at that time. ${ }^{17}$ The southern part of the lower court and the southern front of the upper court had been replaced by earthworks, presumably by Philip de Merode. ${ }^{18}$ Although the castle was embellished for 
a large banquet in 1716, the aldermen decided in 1726 not to gather in the castle any more. The last act was signed in the castle on 26 May 1728. By 1750 the castle had fallen completely into ruins.

\section{THE PLAN OF THE TOWN AND CASTLE ${ }^{19}$}

\section{By WIM DE CLERCQ and STEVEN MORTIER}

The street grid divides the rectangular new town into six plots in which living areas, workshops, and religious and administrative buildings were laid out (Fig. 2). The main street - part of the road from Bruges to Aardenburg - leads to the castle entrance. Initially, the defences consisted of a moat which completely surrounded the town. In 1466 the duke allowed a wall and gates to be added. ${ }^{20}$ On the south-western side, the town moat was connected to two large rectangular moats, separated from each other by an earthen bank, which together set the castle in a wide watery landscape.

The castle was accessed from the town by a bridge over the $25 \mathrm{~m}$-wide moat into the lower court, which was shaped like a $\mathrm{T}$ with its top facing the settlement (Fig. 3). Its gateway was flanked by two small half-round towers with additional small towers on each corner of the facade. The lower court included a gallery and a herb garden. Both parts of the castle were built in brick on a foundation of fine white sandstone from the Gobertange quarries (Brabant-Wallon province), which was just visible above the waterline. ${ }^{21}$

Across another bridge over the second moat, $8 \mathrm{~m}$ wide, lay the upper court, whose entrance facade was defended by massive drum towers at the corners ${ }^{22}$ and a three-quarter-round staircase tower and a large semi-circular tower on either side of the entrance. The only other tower was in the middle of the opposite south-west side of the upper

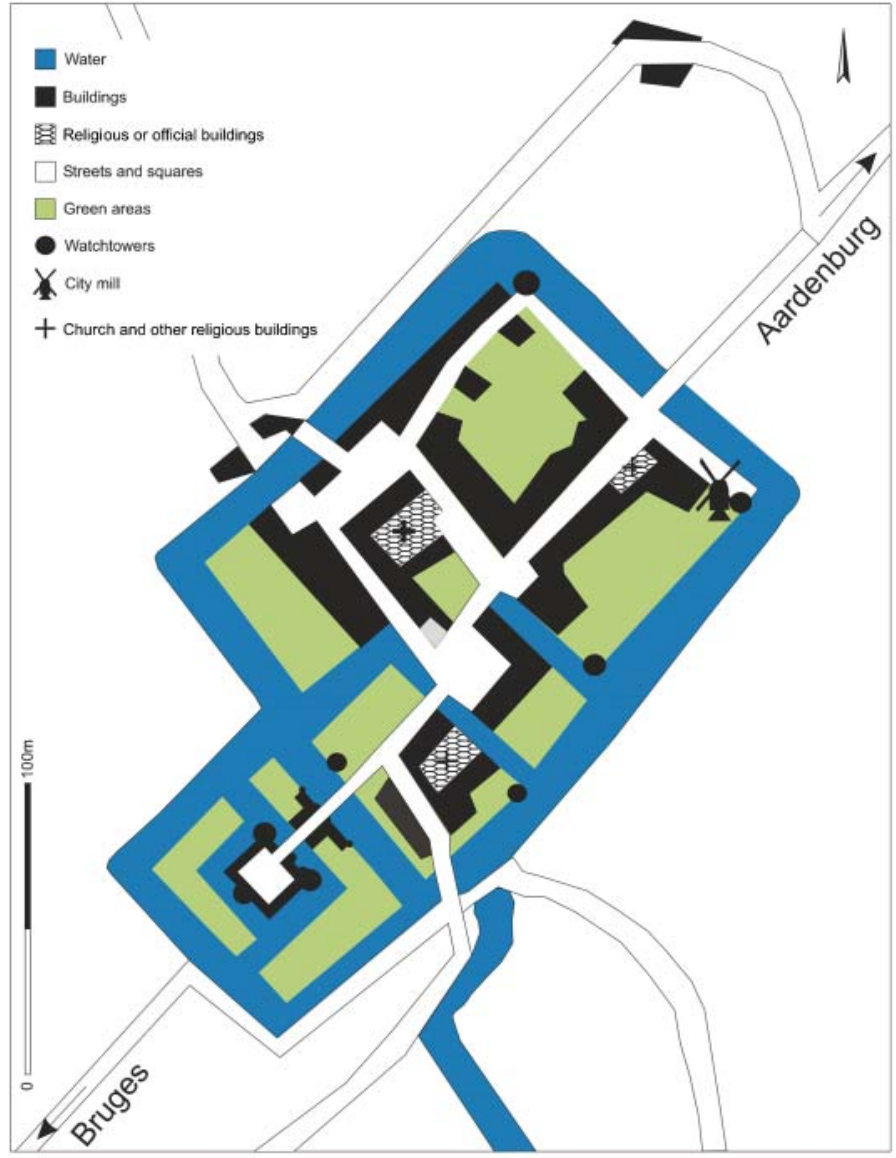

FIG. 2

Simplified plan of the new town of Middelburg, based on the excavation and Jacob Van Deventer's 1550 map. 


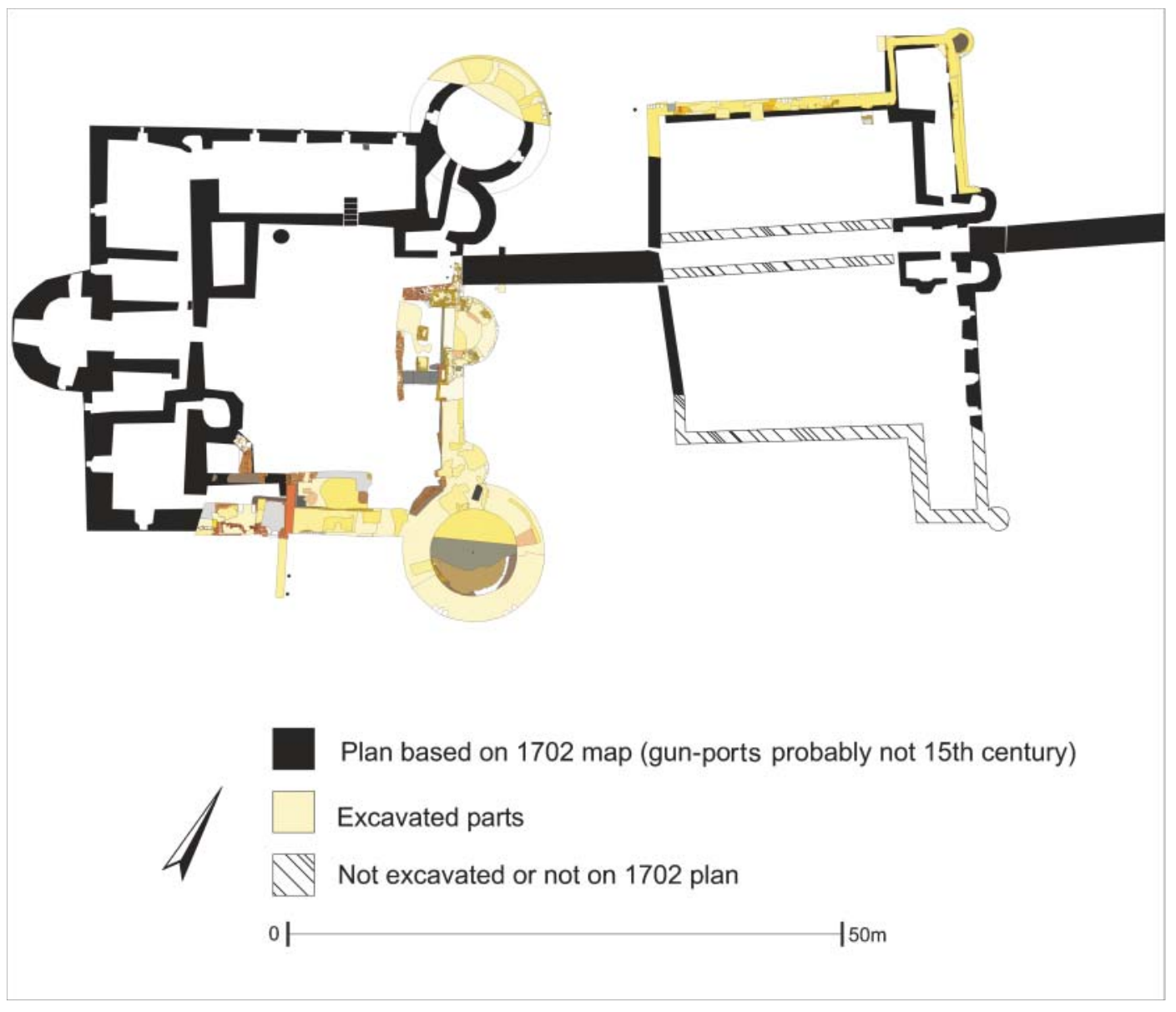

FIG. 3

Simplified plan of Middelburg castle, based on excavation and the 1702 plan.

court. Buildings were ranged round the inner square courtyard. The main residence lay opposite the entrance and could be accessed by a staircase.

\section{THE CONTEXTS}

\section{$B y$ WIM DE CLERCQ and STEVEN MORTIER}

\section{LOCATION IN THE CASTLE}

The garderobe chutes discussed in this paper lay at the front of the upper court (Fig. 4). The canon balls and other projectiles found in its moat during the excavation indicate that this part of the building had suffered heavily from artillery attacks. The excavation plan matches the detailed drawing of the castle made by the French military engineer Senneton de Chermont in May 1702. It shows a large breach in the southern earthworks and significant changes in both courts. Earthworks had replaced much of the southern wings of the lower and upper court, including the excavated garderobes. As Dhooghe explicitly mentioned the southern tower in his account of the events in June 1579 , and as no devastating attacks were recorded between 1590-1604 and between 1604-1702, this part of the castle was presumably destroyed in the period between 1579 and 1590 or in 1604 , and cleared then or later.

\section{THE GARDEROBE CHUTES (FIGS 4-5)}

The two chutes or shafts evacuated waste into the moat from the towers on the upper court's north-eastern facade. Chute $\mathrm{A}^{23}$ lay in the corner between the front wall and the tower flanking the gateway. Square in plan, $400 \times 400 \mathrm{~mm}$, its flat bottom was mortared. The outflow opening in the wall measured $950 \times 400 \mathrm{~mm}$. The upper fill $(-0.300$ to $-1.050 \mathrm{~m}$ below the present surface) consisted 

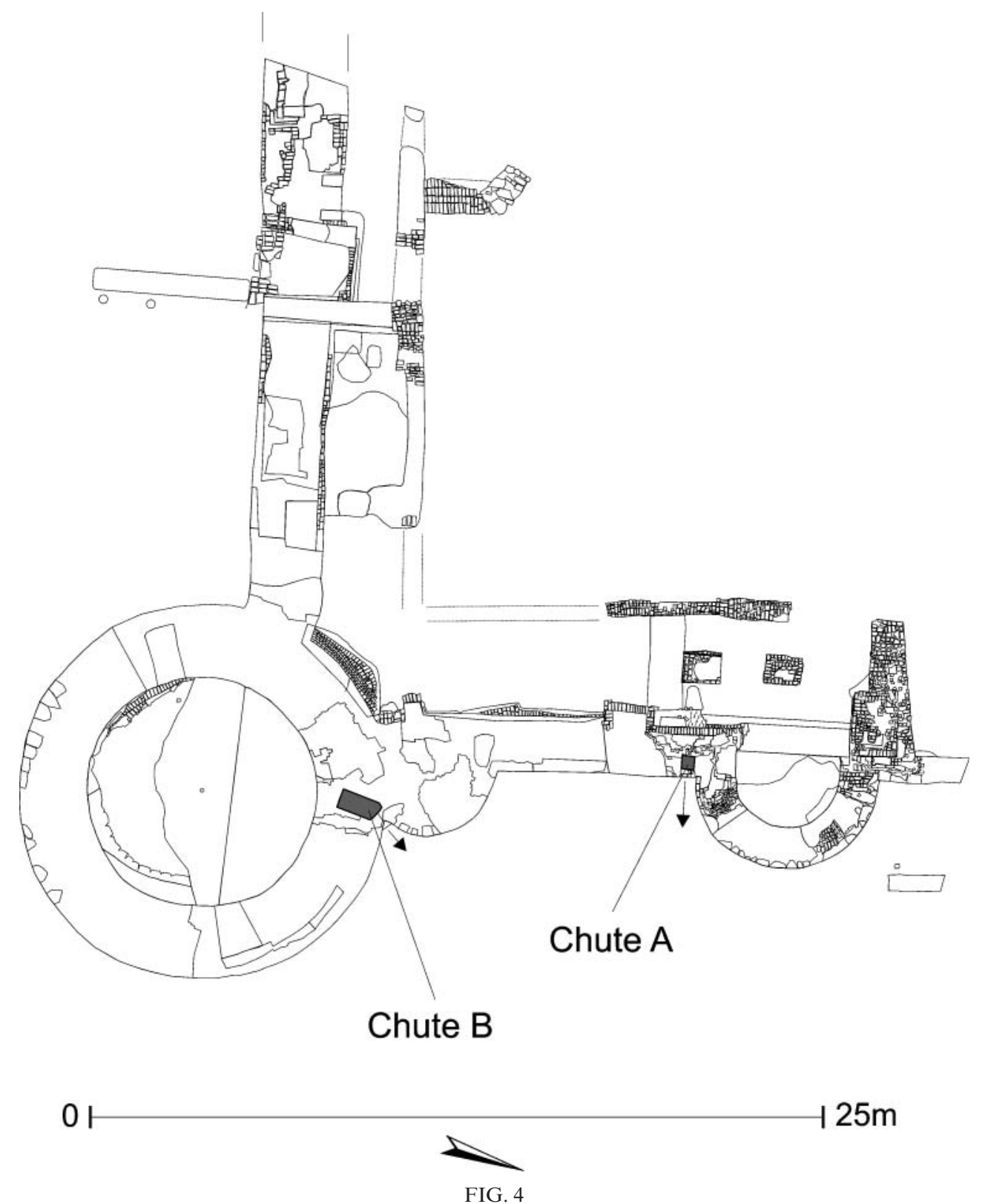

Middelburg castle, upper court. Location of excavated garderobe chutes.

mainly of bricks, slate and mortar. Below $-1.050 \mathrm{~m}$, the deposit changed abruptly into pottery and organic material, belonging to the time when it was used as a chute. This layer continued to the bottom of the chute at $-1.860 \mathrm{~m}$ and into the outflow right to the bottom of the moat at $-2.200 \mathrm{~m}$. Between -1.470 and $-1.860 \mathrm{~m}$ the fills of the chute and the moat were deposited at the same time. They were sampled separately. Only the outflow sediment remained below that. The organic remains preserved below $-1.400 \mathrm{~m}$ point to continuous waterlogging.

The other chute $\mathrm{B}^{24}$ lay at the corner between the large southern corner tower and the adjacent staircase tower. The structure was almost rectangular in plan, $1.250 \times 600 \mathrm{~mm}$, and 


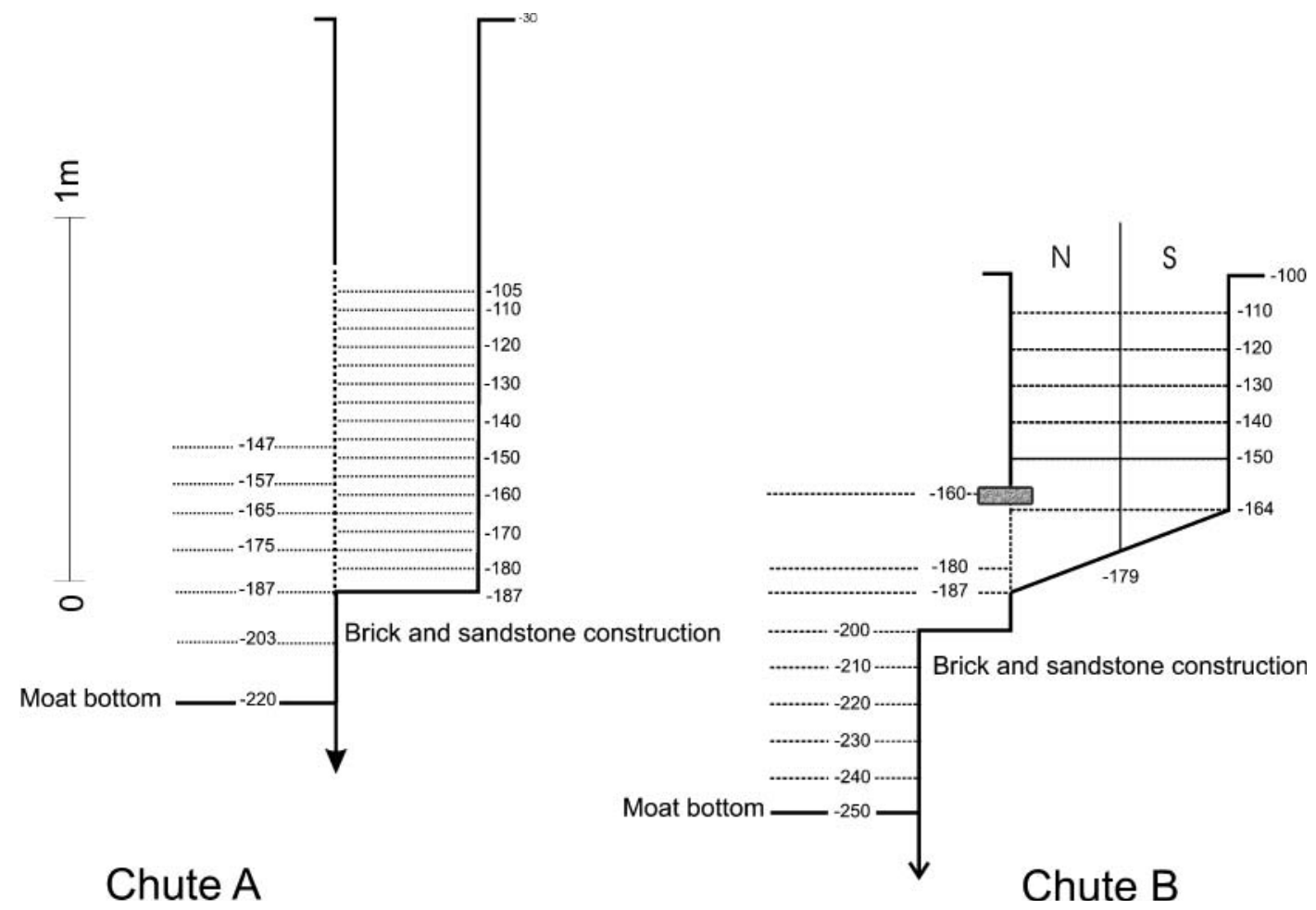

FIG. 5

Middelburg castle, garderobe chutes. Sections indicating spits excavated. Depth below surface in $\mathrm{cm}$.

was preserved below $-1.040 \mathrm{~m}$. Its mortared bottom sloped down at a $40^{\circ}$ angle, ensuring a better evacuation into the moat. This opening measured $600 \times 600 \mathrm{~mm}$ and was encased in white sandstone. The upper layers of its fill consisted almost entirely of bricks, decayed wood, slate and lumps of mortar. At a depth of $-1.450 \mathrm{~m}$ the filling of the pit changed dramatically into an undifferentiated organic sediment, containing glass, pottery, metal and some building materials. Below this depth the sediment seemed to have been continuously waterlogged. The outflow was sampled from -1.600 to $-2.500 \mathrm{~m}$. Between -1.600 and $-1.870 \mathrm{~m}$, the outflow and chute were filled at the same time. They were sampled separately.

\section{SAMPLING STRATEGIES AND \\ TAPHONOMY}

Both chutes' fills and their outflows into the moat were sampled for environmental analysis. Chute A was dug in $50 \mathrm{~mm}$ spits, from each of which a 10-litre sample was taken. Because of the large number of bricks, the outflow was sampled in $100 \mathrm{~mm}$ spits. The larger Chute B was also dug in arbitrary $100 \mathrm{~mm}$ layers with separate 10-litre samples taken from its northern and southern parts. The rest of the fills were searched manually and with a metal detector. Above the waterlogged layer, the water level of the moat seems to have fluctuated between -1.100 and $-1.450 \mathrm{~m}$. The deposits related to the use of the structures as chutes appeared in both structures suddenly, under a layer of bricks, mortar, slate and wood. Some bricks may have sunk into the use-related deposits, which together with their outflows into the moat were rich in organic matter and artefacts. No stratification was observed and it became clear during excavation that pieces of pottery and glass recovered from the uppermost and lowest levels joined to form complete or almost complete vessels.

\section{THE POTTERY}

\section{By KOEN DE GROOTE and PEDRO PYPE}

\section{GARDEROBE CHUTE A}

\section{Introduction}

This chute contained 431 fragments of rather well-preserved pottery vessels (Table 1). The degree 
TABLE 1

Middelburg castle, chute A. Pottery quantification.

Chute A. Pottery Quantification

\begin{tabular}{lrrrr}
\hline & Sherds & MNV & \% sherds & \% MNV \\
\hline Redware & 399 & 79 & $92.6 \%$ & $85.9 \%$ \\
Stoneware & 25 & 9 & $5.8 \%$ & $9.8 \%$ \\
Maiolica & 7 & 4 & $1.6 \%$ & $4.3 \%$ \\
Total & 431 & 92 & $100 \%$ & $100 \%$ \\
\hline $\begin{array}{l}\text { Minimum Number } \\
\text { of Vessels }\end{array}$ & Red & Stoneware & Maiolica \\
\hline
\end{tabular}

\begin{tabular}{|c|c|c|c|}
\hline $\begin{array}{l}\text { Double-handled } \\
\text { jar (grape) }\end{array}$ & 23 & & \\
\hline Skillet & 9 & & \\
\hline Frying pan & 2 & & \\
\hline Lid & 1 & & \\
\hline Colander & 1 & & \\
\hline $\begin{array}{l}\text { Large carinated } \\
\text { bowl }(\text { teil })\end{array}$ & 4 & & \\
\hline Bowl & 4 & & \\
\hline Porringer & 6 & & \\
\hline Dish & 3 & & 1 \\
\hline Tankard & & 2 & \\
\hline Jug & 2 & 1 & \\
\hline Oil jug & & 5 & \\
\hline $\begin{array}{l}\text { Concave-sided jar } \\
\text { (gallipot/albarello) }\end{array}$ & 17 & & 3 \\
\hline Bird pot & 2 & & \\
\hline Spindle whorl & & 1 & \\
\hline Other/unknown & 5 & & \\
\hline Total & 79 & 9 & 4 \\
\hline \multicolumn{4}{|c|}{ MNV } \\
\hline Food preparation & 44 & & $47.8 \%$ \\
\hline Table ware & 20 & & $21.7 \%$ \\
\hline Personal care & 20 & & $21.7 \%$ \\
\hline Others/unknown & 8 & & $8.7 \%$ \\
\hline Total & 92 & & $100 \%$ \\
\hline
\end{tabular}

$\mathrm{MNV}=$ Minimum Number of Vessels.

of fragmentation was low. Sherds from the same vessels were scattered from the top to the bottom of the chute. Most could be fitted together. The minimum number of vessels (MNV) is 92 , amongst which are several intact jars. The assemblage contains three main ceramic groups: redware, stoneware and tin-glazed ware. The redware is of local or regional origin and forms by far the largest part of the assemblage (sherd count 92.6\%, MNV 86\%). The others were imported, the stoneware from the Rhineland (sherd count 5.8\%, MNV 9.8\%) and a few fragments of Low Countries maiolica (sherd count 1.6\%, MNV 4.3\%).

\section{Fabrics and typology}

\section{Redware}

The sandy fabric contains fine rounded grains of less than $0.3 \mathrm{~mm}$. Its colours range from orangered and orange-brown to red, dark-red and brownred. Usually the pottery is partly covered with a lead glaze. Seventy-eight MNV were counted and fourteen redware forms could be identified: double-handled jars (the so-called grape cooking pots), skillets, frying pans, two bowl types, porringers, dishes, a colander, jugs, a lid, jars, bird pots and two special forms.

The double-handled jars (grape) are by far the best represented form in this assemblage (23 MNV, $29.1 \%$ ) (Figs 6:1-14; 7:15-21). All items belong to the same form type, characterized by a wide rim opening, a short neck and a base with thumbed feet. Two rim types can be distinguished. Eight of the 20 measurable examples are small (rim diam. $150-200 \mathrm{~mm}$, height $110-150 \mathrm{~mm}$ ); and another eight are even smaller (rim diam. 110 $150 \mathrm{~mm}$, height $80-110 \mathrm{~mm}$ ). All were intensively used: they are blackened by soot and some of them have scratches on the inside glaze. Double-handled jars on thumbed (instead of tripod) feet are characteristic of the Flemish coastal area. ${ }^{25}$

Small-handled open forms with a plain handle and a pouring lip can be identified as skillets (Figs 7:22-6; 8:27-8). Remarkably, all six more-orless complete examples represent as many different subtypes, which vary in body, base or rim shape. The skillets have also been intensively used on the fire, shown by their blackened exteriors. Three examples were scratched inside. The skillet is a popular form in the 16th century and later and occurs throughout Flanders. ${ }^{26}$

The context contains two frying pans both of a small type with a plain handle and a pouring lip (Fig. 8:29). Some slight traces of soot are visible. A typical lid has a flared, thumb-impressed knob handle and a simple angular rim (Fig. 8:30). It is unglazed, with traces of soot on the rim.

The colander and the large carinated bowl are pottery vessels used in the preparation of cold foods. The tripod colander has a rounded body (Fig. 8:31) and a square rim with thumbed decoration. The inside is covered with a white slip and a green-coloured glaze. Three large carinated bowls with a flared body and a collared rim belong to a particular type of kitchen utensil, called in Dutch teil (Fig. 8:32-3). A small bowl is a smaller example of this form, with the typical wide pouring lip preserved (Fig. 8:34). Only the inside is glazed. 

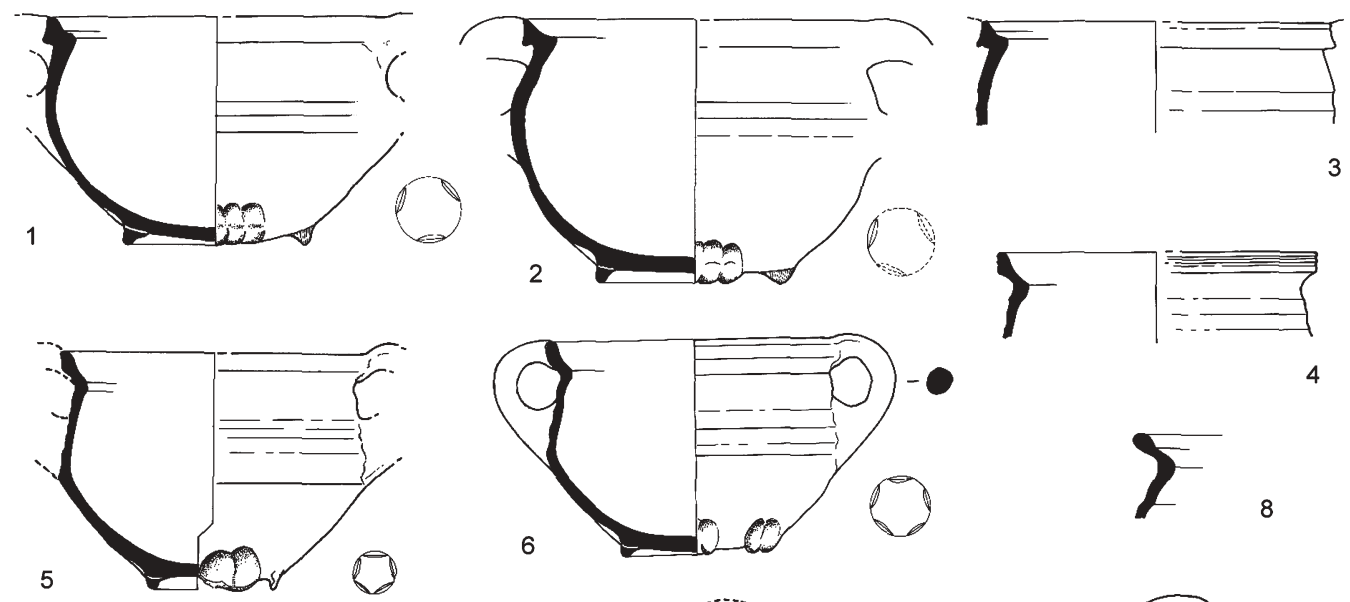

5

0

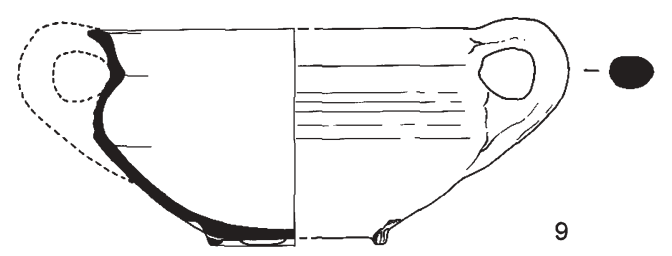

7
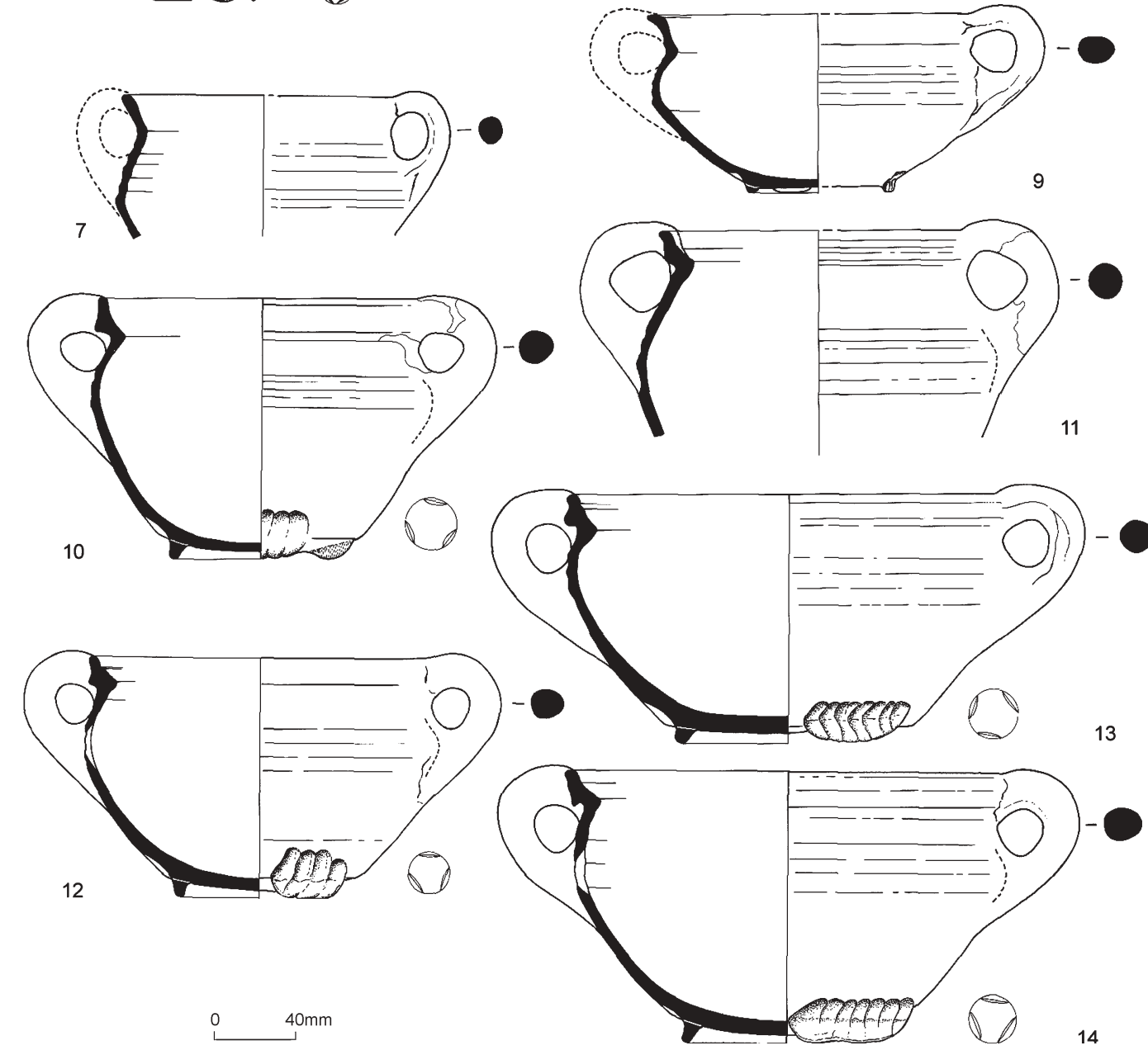

FIG. 6

Middelburg castle, chute A. Local or regional redware pottery: 1-14. double-handled jars. 


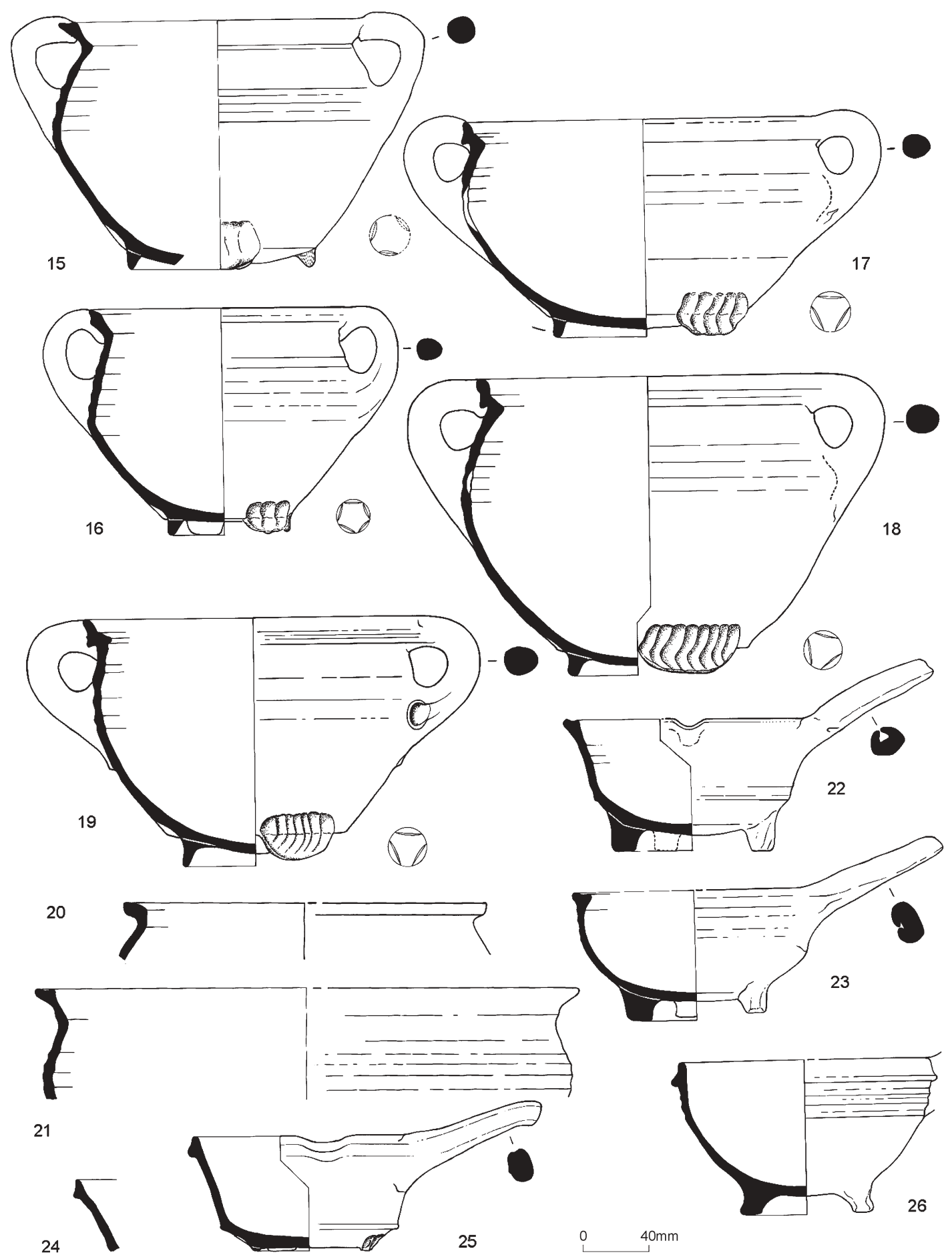

FIG. 7

Middelburg castle, chute A. Local or regional redware pottery: 15-21. double-handled jars; 22-6. skillets. 

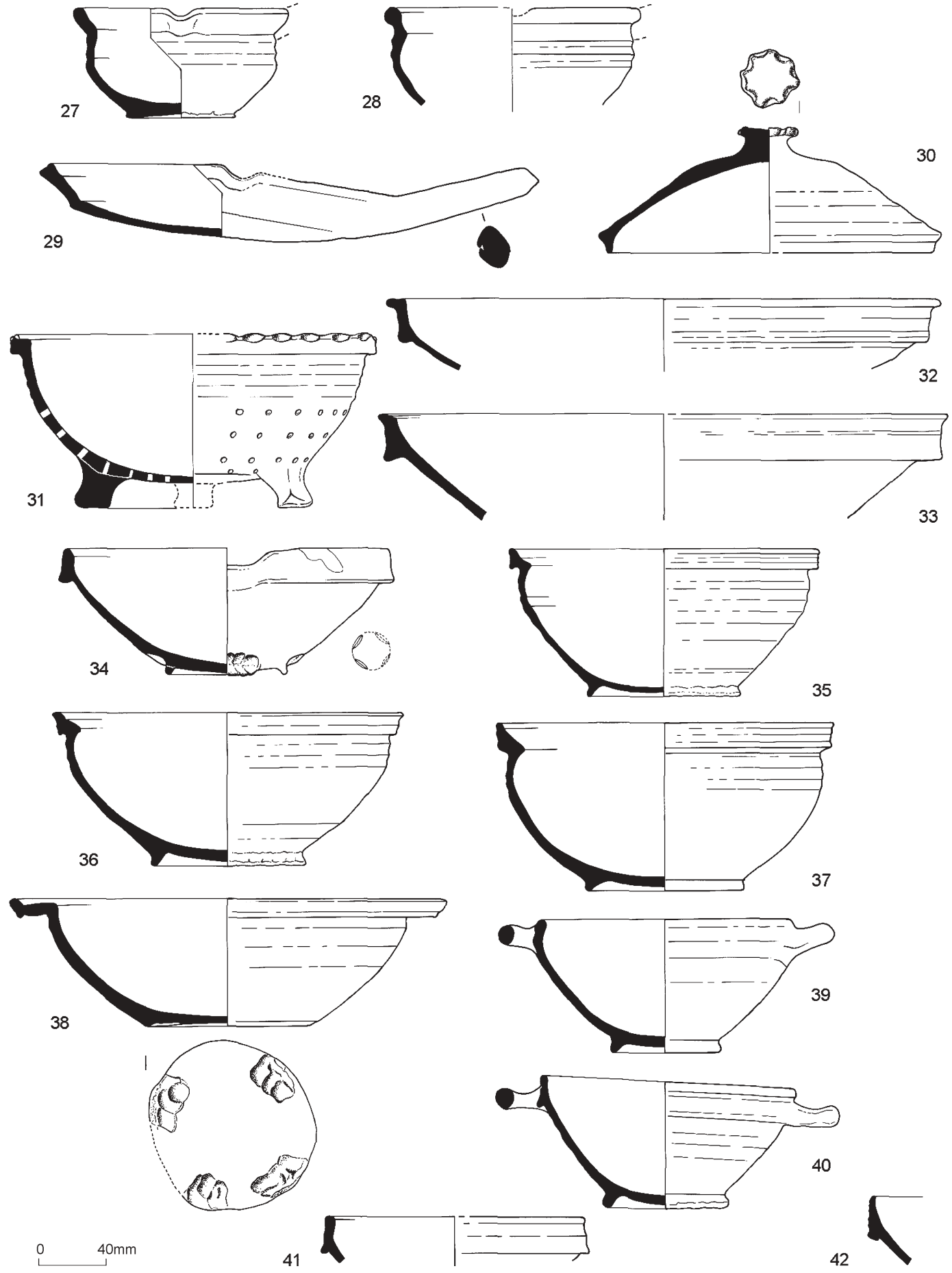

42

FIG. 8

Middelburg castle, chute A. Local or regional redware pottery: 27-8. skillets; 29. frying pan; 30. lid; 31. colander; 32-8. bowls; 39-42. porringers. 
This bowl shape developed in the 13th century and was popular in the Low Countries until the 18th century. ${ }^{27}$ Four other bowls belong to a rounded type with a restricted neck. Three of these have the same rilled collared rim and a footring (Fig. 8:35-7). The last example is a special type, with a wide brim and a peculiar concave base with four slight thumbed feet (Fig. 8:38). They are all glazed on the inside, except for one which is completely glazed.

Six small bowls can be classified as tableware porringers (Figs 8:39-42; 9:43-4). They are characterized by a flaring body on a footring and a strap-shaped rim with two opposing horizontal loop handles springing from the collar. One example has a deviant, simple rim shape; another one has a flat, slightly concave, base. All are decorated. Four have a white slip layer on the inside, finished with a green-coloured lead glaze (Fig. 8:39-42). The outside is unglazed. Two other porringers bear a text on the outside of the rim: $O$ MATER DEI: MEMENTO [MEI]. The letters on one were incised through a white slip into the red clay (Fig. 9:43). On the outside only the collar was glazed, resulting in red letters on a yellow background. The inside is also covered with a slip and a green glaze. The text on the other example was painted in white slip (Fig. 9:44). The plain lead glaze on the rim gives the effect of yellow letters on a red background. The inside was glazed, but not slipped. During the 15 th century, this type of porringer became popular, ${ }^{28}$ but examples decorated with a religious text are rare. The only comparable porringer with a partially preserved sgraffito text is from Bruges and dated to the second half of the 16th century. ${ }^{29}$ Two typologically different two-handled pots with a similar Marian text were found in Middelburg (Zeeland, the Netherlands) ${ }^{30}$ and in Petegem (Belgium). ${ }^{31}$

The assemblage contains three dishes. A small example rests on a footring and has a plain lead glaze on the inside (Fig. 9:45). A large example has a diameter of about $360 \mathrm{~mm}$ (Fig. 9:46). It has a simple white slip decoration on the brim of simple dot rosettes alternating with a barred S-scroll. Only the inside is lead glazed.

A particular form of tableware is represented by only one one-handled large mug (tas in Dutch) (Fig. 9:47). It has a rather tall, cylindrical, rilled body and a simple everted rim with one vertical loop handle on the body. This small vessel is completely covered with lead glaze, which on the inside lies over a white slip, resulting in a yellow colour. Sixteenth-century examples of this form are known from Antwerp, Aalst, Brussels and elsewhere. ${ }^{32}$

Only two jugs in red earthenware were recovered. A complete specimen has a rather ungainly rounded shape on a footring (Fig. 9: 48). Both the inside and the outside are completely glazed.

The most striking aspect of this assemblage is the presence of a large number of gallipots or concave-sided jars, seventeen of which are in red earthenware (Fig. 9:49-65). They all derive from the same form characterized by a cylindrical, slightly concave body, a flat or concave base and a simple everted rim. Only the inside of these vessels is completely glazed, with some glaze splashes on the outside. Their height varies between 50 and $90 \mathrm{~mm}$. One jar is larger and wider than the others (rim diam. 95mm, height $105 \mathrm{~mm}$ ) and is completely glazed (Fig. 9:65). A green glaze covers a layer of white slip on the outside. A clear glaze was used instead on the inside.

Some objects were made in unglazed red earthenware. A rather large single-handled jar has an everted thickened rim with one vertical loop handle (Fig. 9:66). The ovoid body rests on three thumbed feet. Its shape is related to the chamber pot, but the absence of glaze (especially on the inside) and of any traces of use (e.g. a chalk-like residue) suggests that it must have had another unknown function. Fragments of a second example are from a similar but smaller type (Fig. 9:67).

Another unglazed vessel form is the bird pot. One more-or-less complete example and one neck fragment were found (Fig. 10:68-9). They have a rounded body, a long grooved, narrow neck with a simple rim and one or two pierced lugs on the neck. The lenticular base has a rod loop handle, set on the opposite side of the neck lugs. Before firing, a square hole was cut through the base. Bird pots are typical of the 16th century and were used to attract and house starlings. ${ }^{33}$ Sixteenth-century paintings and prints by Pieter Brueghel the Elder (1525-69) and his contemporary Pieter van der Heyden (c. 1530-75) often depict bird pots hanging on the outside of houses. ${ }^{34}$ The pierced lugs were intended to hold a horizontal wooden perch. The cut-out opening in the base allowed the owner to take eggs or young birds from the nest for food.

\section{Maiolica $^{35}$}

The assemblage contains fragments of five items in maiolica produced in the Low Countries: three jars, a plate rim and the body fragment of a small jug. All were made in whitish, pale beige-coloured fine clay, with a few small red inclusions.

Two small concave-sided jars or albarelli (rim diam. $41 \mathrm{~mm}$, height $55 \mathrm{~mm}$ ) have a simple decoration. The plain white tin glaze of one was painted with a pattern of four pairs of vertical parallel lines, alternating a blue and yellow pair with an ochre 


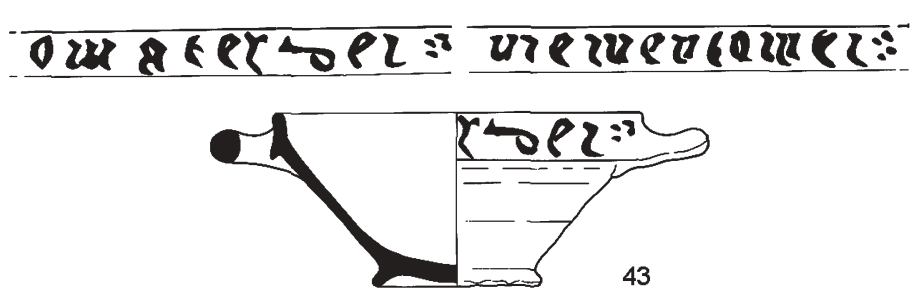

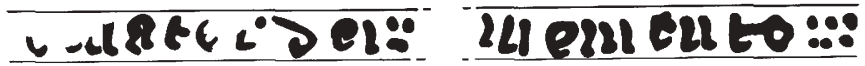
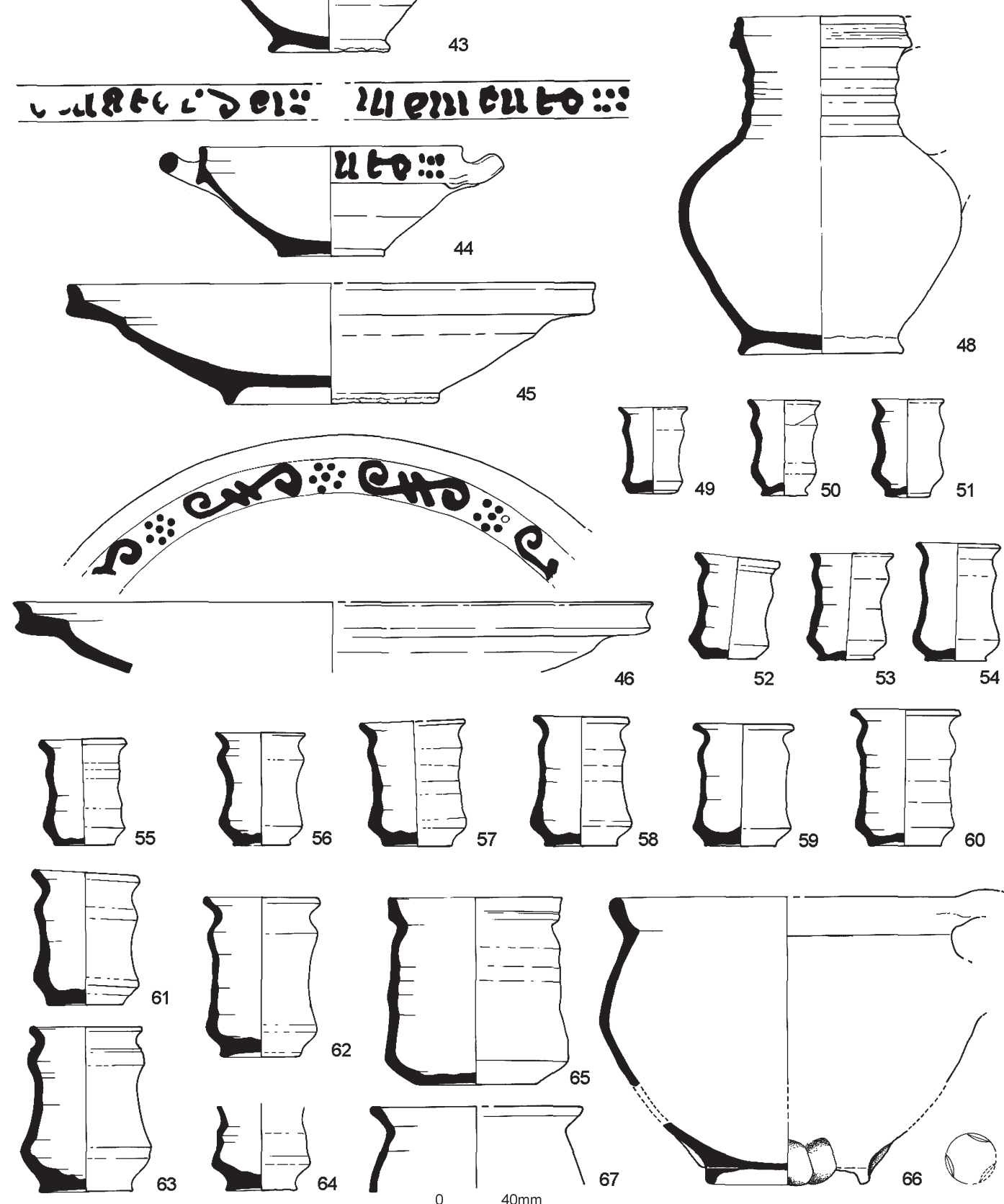

\section{FIG. 9}

Middelburg castle, chute A. Local or regional redware pottery: 43-4. porringers; 45-6. dishes; 47. mug; 48. jug; 49-65. concave-sided jars; 66-7. large jars. 

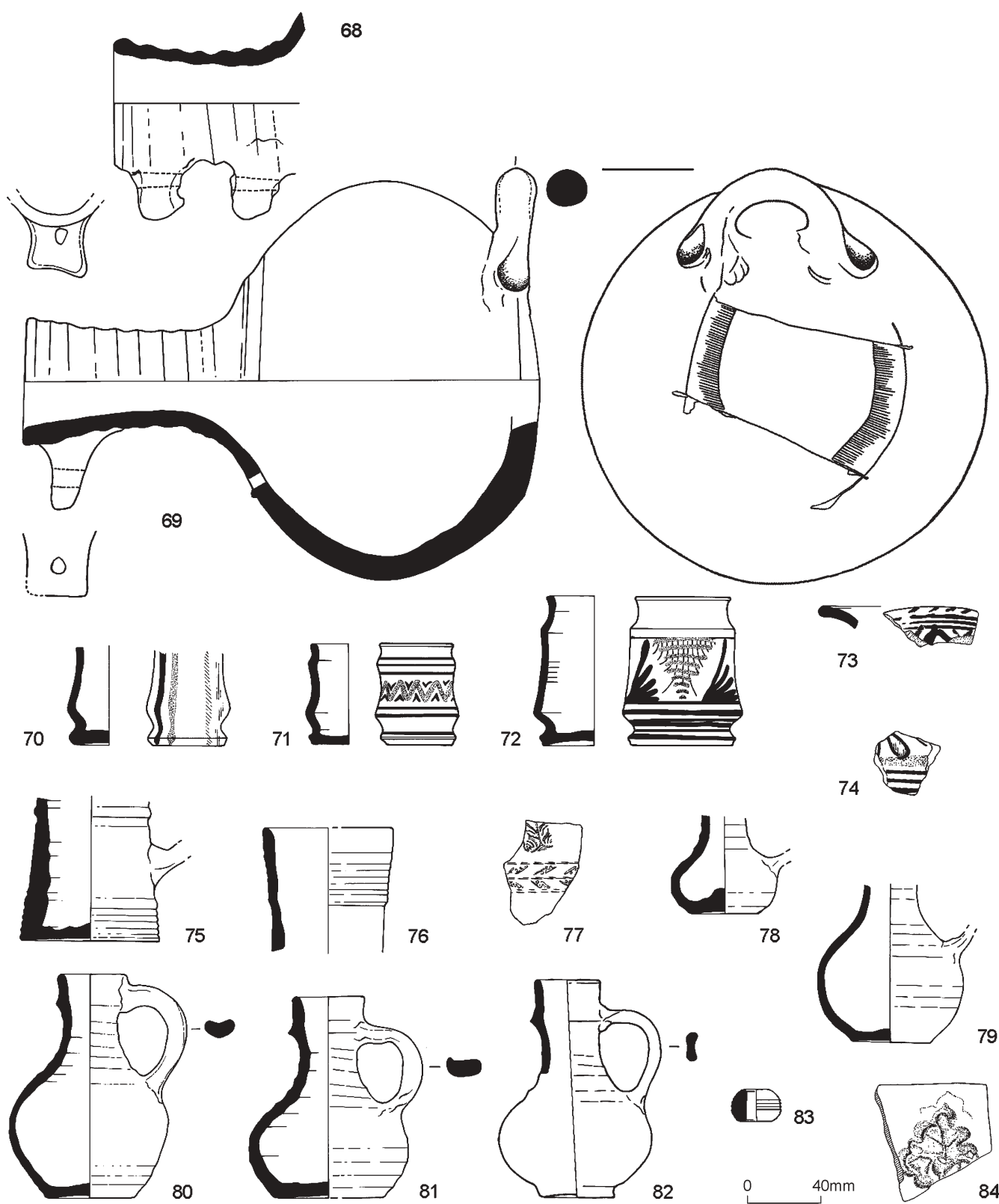

78

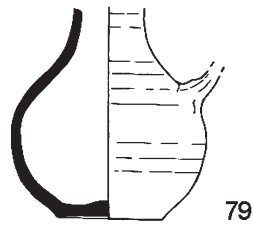

FIG. 10

Middelburg castle, chute A. Local or regional redware ceramics: 68-9. bird pots; 84. stove tile. Low Countries maiolica: 70-2. concave-sided jars; 73. dish; 74. jug. Rhenish stoneware: 75-6. mugs; 77. Bartmann jug; 78-82. oil jugs; 83. spindle whorl.

brown and green pair (Fig. 10:70). The second small jar has a patchy bluish-white tin glaze with in the centre a yellow zigzag line separating small blue Vs (Fig. 10:71). The three blue horizontal lines below and above are not clearly visible on the patchy blue ground. The combination of blue and yellow is known on Antwerp maiolica of the second half of the 16th century. ${ }^{36}$ The third jar is larger (rim diam. 53mm, height $80 \mathrm{~mm}$ ) (Fig. 10:72). The foot and neck are decorated with horizontal 
blue lines framing stylized foliage in ochre yellow. This type of decoration is known in 16th-century Antwerp workshops. ${ }^{37}$

A small rim fragment from a dish bears geometric decoration in blue and ochre yellow (Fig. 10:73). This type of dish and the combination of two-coloured geometrical decoration with a blue cable pattern on the rim have been found in Antwerp consumer sites of the second half of the 16th century. ${ }^{38} \mathrm{~A}$ small polychrome painted body fragment comes from a jug (Fig. 10:74). Green (leaves?) defined with a blue line were painted above three parallel blue lines and a broader one in yellow.

\section{Stoneware}

Stoneware is represented by only nine items in chute A, an unusual pattern for this period. Normally tableware dominates, but this assemblage contains fragments of only two tankards (cylindrical mugs) and one jug. The flat base comes from a tankard of the smaller Pinte type (Fig. 10:75), while the rim fragment belongs to a medium-sized tankard of the Schnelle type (Fig. 10:76). Both were made in Raeren or Aachen and can be dated between the second quarter and the end of the 16th century. ${ }^{39}$ The decorated body fragment from a foliate band jug, probably a Bartmann, was produced in Cologne or Frechen between 1520 and 1550 (Fig. 10:77). ${ }^{40}$ More remarkable is the set of five small long-necked Raeren rounded jugs on a flat base (Fig. 10:78-82). Four of them are of the same size (height between 110 and $120 \mathrm{~mm}$ ); an incomplete example is much smaller. They are thought to have held oil used in spinning. These small oil jugs are generally dated to the 16th century, ${ }^{41}$ but in the Low Countries most have been found in contexts of the first half of that century. ${ }^{42}$ The last stoneware object is a spindle whorl (Fig. 10:83), a typical Raeren product dated between the late 15th and the third quarter of the 16th century. ${ }^{43}$

\section{GARDEROBE CHUTE B}

\section{Introduction}

Although the volume of the contents of this chute was more than double that of chute A, it yielded only half the amount of ceramics. The assemblage contains 305 fragments, representing $34 \mathrm{MNV}$ (Table 2). As in chute A, the degree of fragmentation was low and most of the sherds could be fitted together to make almost complete vessels. Here too, matching fragments were found scattered from the top to the bottom of the fill. The assemblage also has more or less the same
TABLE 2

Middelburg castle, chute B. Pottery quantification.

Chute B. Pottery Quantification

\begin{tabular}{lrccc}
\hline & sherds & MNV & \% sherds & \% MNV \\
\hline Redware & 291 & 29 & $95.4 \%$ & $85.3 \%$ \\
Stoneware & 12 & 4 & $3.9 \%$ & $11.8 \%$ \\
$\begin{array}{l}\text { Maiolica } \\
\text { Total }\end{array}$ & $\mathbf{3 0 5}$ & 1 & $0.7 \%$ & $2.9 \%$ \\
$\begin{array}{l}\text { Minimum Number } \\
\text { of Vessels }\end{array}$ & Red & Stoneware & Maiolica \\
\hline
\end{tabular}

\begin{tabular}{|c|c|c|c|}
\hline $\begin{array}{l}\text { Double-handled jar } \\
\text { (grape) }\end{array}$ & 5 & & \\
\hline Skillet & 1 & & \\
\hline Colander & 1 & & \\
\hline $\begin{array}{l}\text { Large carinated bowl } \\
\text { (teil) }\end{array}$ & 7 & & \\
\hline Porringer & 3 & & \\
\hline Dish & 2 & & 1 \\
\hline Chamber pot & 3 & & \\
\hline Tankard & & 1 & \\
\hline Jug & & 1 & \\
\hline Oil jug & & 2 & \\
\hline $\begin{array}{l}\text { Concave-sided jar } \\
\text { (gallipot) }\end{array}$ & 4 & & \\
\hline Bird pot & 1 & & \\
\hline Other/unknown & 2 & & \\
\hline Total & 29 & 4 & 1 \\
\hline \multicolumn{4}{|c|}{ MNV } \\
\hline Food preparation & 14 & & $41.2 \%$ \\
\hline Table ware & 10 & & 29.4 \\
\hline Personal care & 7 & & $20.6 \%$ \\
\hline Others/unknown & 3 & & $8.8 \%$ \\
\hline Total & 34 & & $100 \%$ \\
\hline
\end{tabular}

$\mathrm{MNV}=$ Minimum Number of Vessels.

composition, made up of three wares. The redware of local or regional origin is by far the largest group (MNV 84.8\%). The imports include stoneware from the Rhineland (11.8\% MNV) and two small sherds of a tin-glazed dish, probably made in Italy. A group of stove-tiles from this chute is discussed separately.

\section{Fabrics and typology}

Redware

The redware fabric has the same characteristics as those of chute A. Twenty-nine MNV were counted 
and ten redware forms identified: double-handled jars (grape), a skillet, a large carinated bowl (teil), porringers, dishes, a colander, chamber pots, jars, a bird pot and one special form.
Five double-handled jars (grape) are similar to those from chute A, but here the larger examples predominate (Fig. 11:85-9). The round body rests on five thumbed feet in the larger cases and on
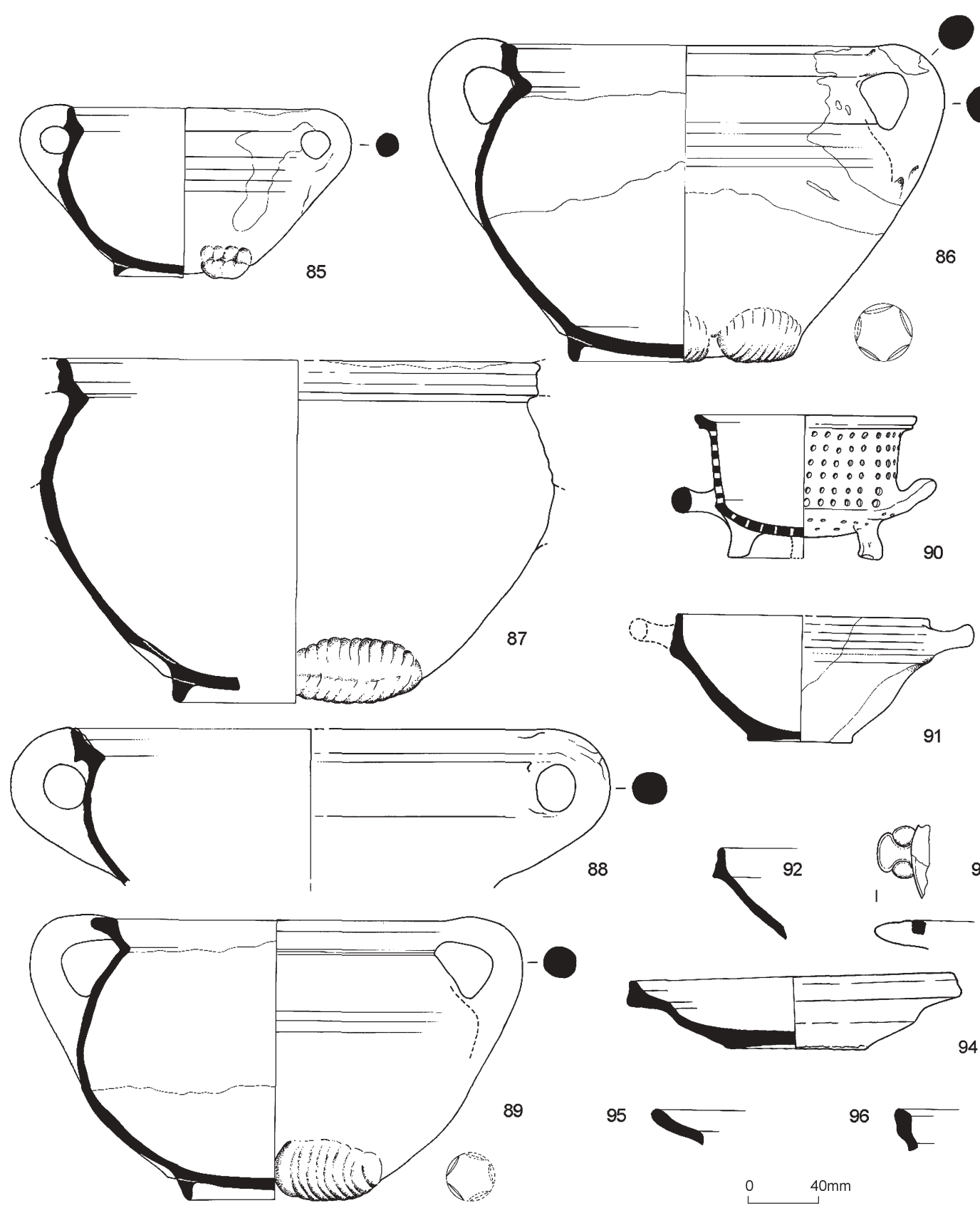

8

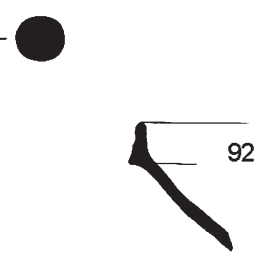

91

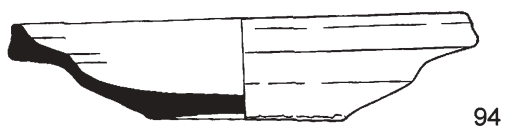

95

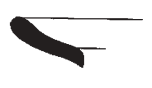

96

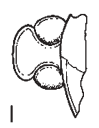

FIG. 11

Middelburg castle, chute B. Local or regional redware pottery: 85-9. double-handled jars; 90. colander; 91-3. porringers; 94-5. dishes; 96. skillet. 
three for the small one. The collared-rim type is again dominant. Two of the larger examples lack soot traces (Fig. 11:87, 89); only the largest one is blackened (Fig. 11:88).

The skillet is represented by only two blackened rim fragments of the small collared type (Fig. 11:96) and a plain handle. This chute contains a smaller colander (Fig. 11:90) than the one found in A. The cylindrical body with two horizontal loop rod handles has a convex tripod base. It is completely glazed inside and out. A parallel was found in a 16th-century cesspit in Bruges. ${ }^{44}$

The double-handled porringer is represented by three items (Fig. 11:91-3). A complete example has a flat base, and is undecorated. A large rim fragment is covered inside with a white slip and green glaze (Fig. 11:92). The small fragment of a third vessel has an everted rim with a trefoil lug handle attached to it (Fig. 11:93). This redware bowl type seems to be rare in the Low Countries. A trefoil-lugged bowl with the same rim type was found in a chute in Nijmegen in the Netherlands, dated to the second quarter of the 16th century. ${ }^{45}$

A complete small dish on a flat, slightly concave base has a typical hammer-headed rim and is glazed on the inside (Fig. 11:94). Another is represented by a simple everted rim (Fig. 11:95).

Six carinated bowls are of the teil type, characterized by a flaring body and a wide collared rim with a large pouring lip (Fig. 12:98-101). A smaller example is also present in this assemblage (Fig. 12:97). Only the inside is glazed.

There are three chamber pots, a form absent from chute A (Fig. 11:102-4). They belong to three different types: rounded with a flat base and a thickened everted rim (Fig. 11:102), more cylindrical with a flat base and a grooved collared rim (Fig. 12:103), and rounded with a footring and a grooved collared rim (Fig. 12:104).

This assemblage also contains four jars (Fig. 12:105-7). Two complete concave-sided examples and a partly preserved one have the same form described in chute A. A fourth fragmentary specimen lacks the concave body (Fig. 12:107). They are all completely glazed on the inside.

An almost complete item is typologically unknown. It is a heavy, open cylindrical form with an upright simple rim, a slightly concave base and two opposed plain lugs located centrally on the body (Fig. 12:108). Two other characteristics are remarkable: the thick walls and unglazed beige fabric. The form, sturdiness and weight point to its use as a mortar. Some minor traces of soot are visible on one side from rim to base. No use marks were found inside.
The last form identified is a bird pot, represented by the body fragments of one vessel (Fig. 13: 109). It is of the same type as the complete one found in chute $\mathrm{A}$.

\section{Stoneware}

Only twelve sherds of stoneware, belonging to four separate items, were found. As in chute A, the oil jug is the commonest form (Fig. 13:112-13). A neck fragment belongs to a medium-sized tankard of the Schnelle type (Fig. 13:110). A large slightly concave base in a dark grey fabric with a brown mottled surface and a shiny salt-glaze can be classified as a medallion jug (Fig. 13:111), which is a typical Raeren form, produced in the second half of the 16 th and the early 17 th century. ${ }^{46}$

\section{Maiolica}

Two small plain fragments come from a fluted dish with a footring base. They are of a rather hard, fine and compact fabric, pink to yellow in colour. A thick layer (up to $1 \mathrm{~mm}$ ) of white tin-glaze was applied on both sides. The form and fabric point to an Italian product. The manufacture of fluted dishes (or crespine), a form copying metal vessels, started in the first half of the 16th century in Faenza. During the last quarter of the 16th century it was also made in the Florence area ${ }^{47}$ The oldest finds of crespine in the Low Countries (which are usually decorated) date from the last quarter of the 16th century and the first quarter of the 17th century. ${ }^{48}$

\section{INTERPRETATION AND DISCUSSION}

Comparison of the two ceramic assemblages reveals similarities and differences. Three aspects will be discussed: taphonomy, composition and chronology. Despite the fact that the volume of chute A was only half of that of chute B, it contained nearly twice as much pottery. This may reflect different patterns of refuse disposal. But potsherds from all spits within each chute crossfitted, ${ }^{49}$ which indicates that both structures were filled only once by dumping a combination of household waste, food remains and rubble.

The composition of the two ceramic assemblages resembles each other in many ways. The proportion of redwares of local or regional origin compared to that of the imported stoneware is more or less the same (Tables 1-2). Also the range of forms is remarkably similar since ten of the fifteen identified forms are found in both pits, including some less common types such as the colander, the bird pot and the small stoneware oil jug. The absence of some forms in chute B is not 

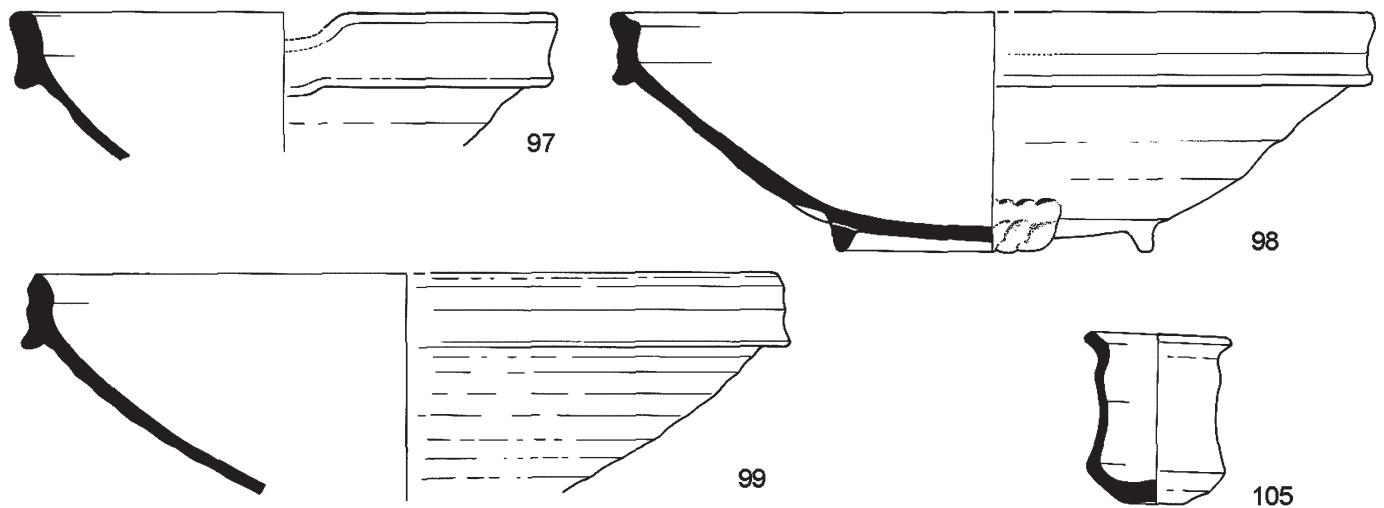

105
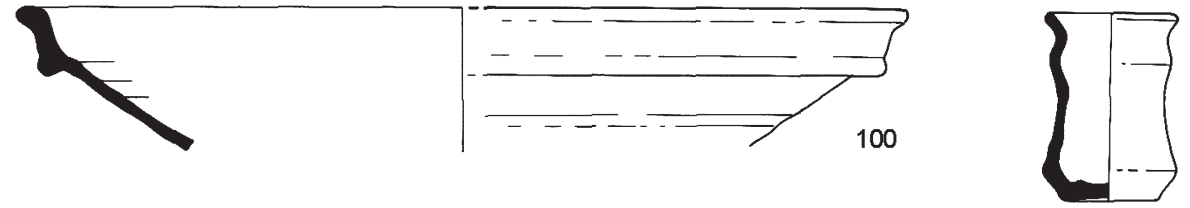

106
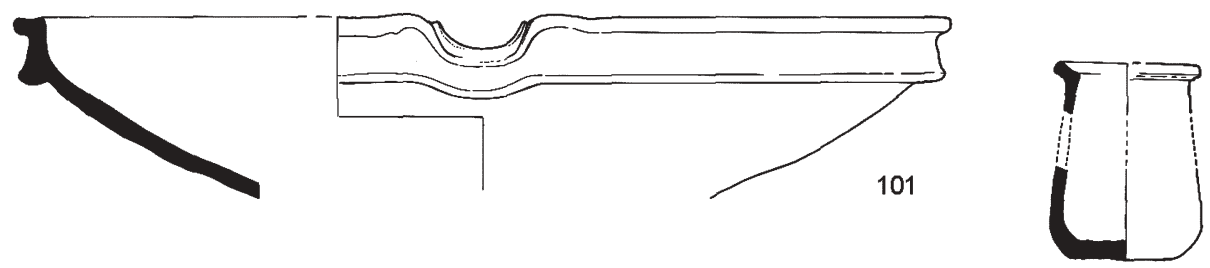

107
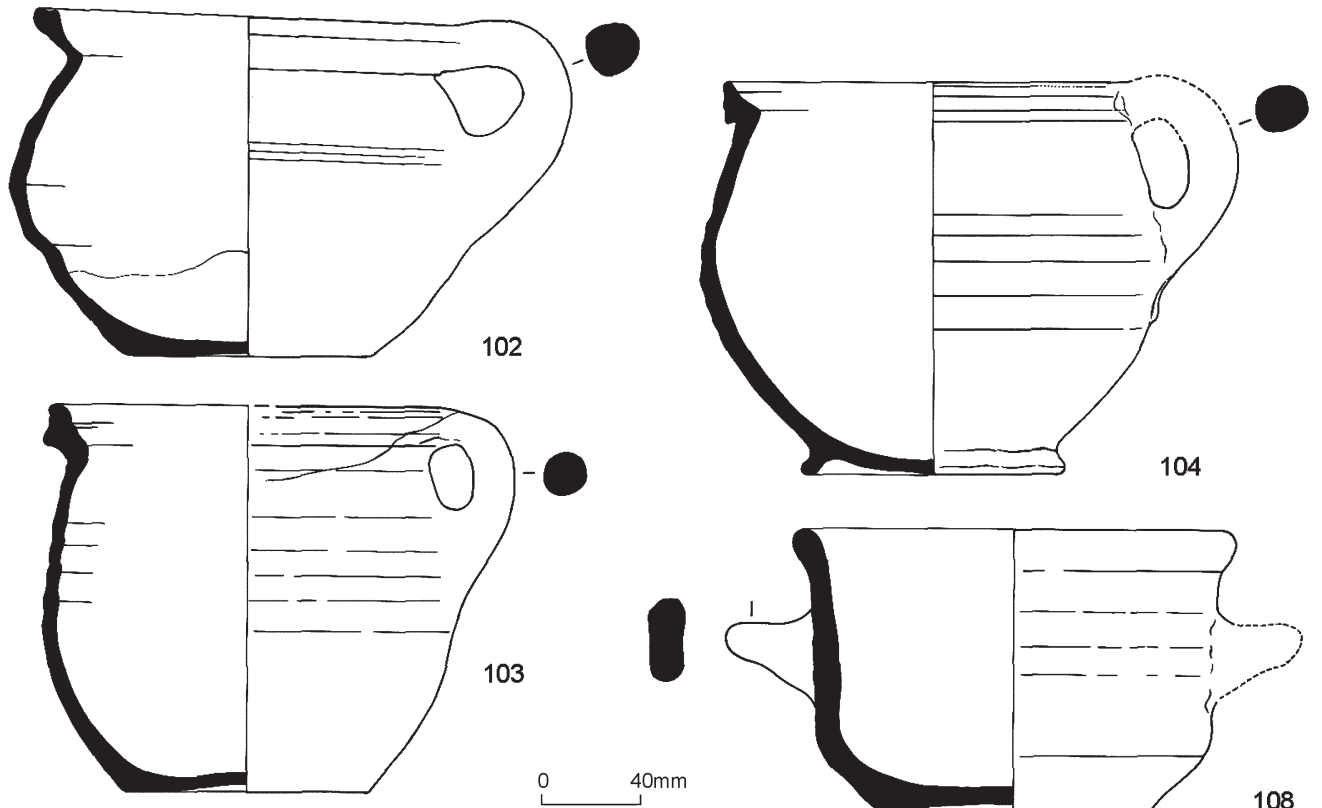

FIG. 12

Middelburg castle, chute B. Local or regional redware pottery: 97-101. carinated bowls; 102-4. chamber pots; $105-7$. concave-sided jars; 108. ?mortar. 

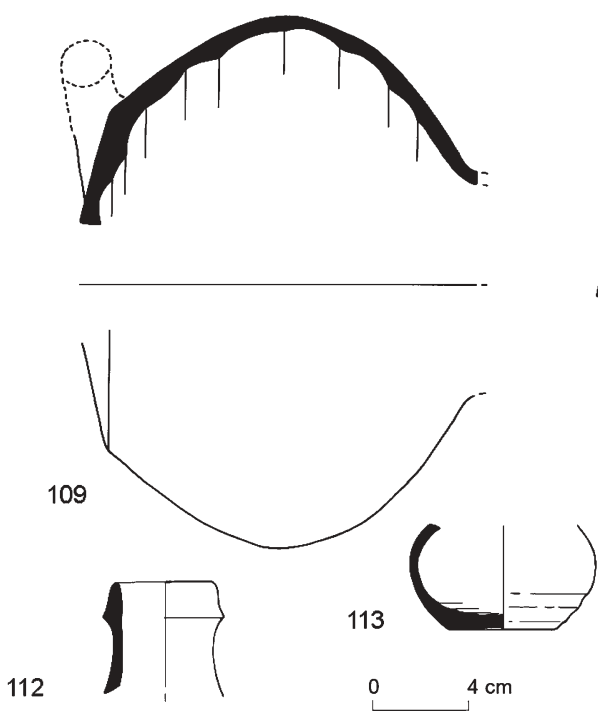

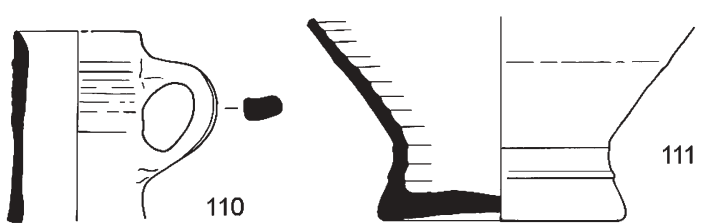

110

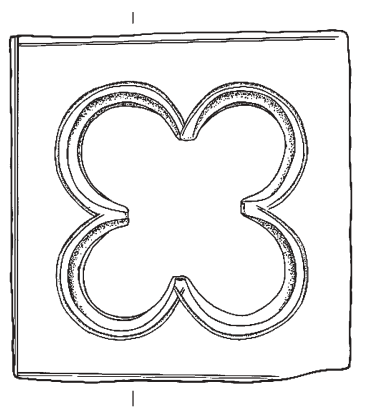

FIG. 13

Middelburg castle, chute B. Local or regional redware pottery: 109. bird pot; 114. stove tile. Rhenish stoneware: 110. mug; 111. jug; 112-13. oil jugs.

unusual; the frying pan is no longer that common in the 16th century, nor is the lid. ${ }^{50}$ Only the lack of chamber pots in A is remarkable, since they were commonly used in this period..$^{51}$ Unparalleled is the high number of gallipots in both chutes (respectively $21.5 \%$ and $13.8 \% \mathrm{MNV}$ ).

Based on general knowledge of the local and regional ceramic evolution in Flanders and the Low Countries, the redwares can be dated to the 16 th century. In terms of fabric and form types, no real differences between the chutes are apparent. The stoneware and the tin-glazed pottery offer more chronological clues, albeit slightly contradictory. The oil jugs and the spindle whorl are usually dated to the 16th century, but judging from other consumer sites in the Low Countries and elsewhere, they were commonly used in the first half or in the middle of that century. On the other hand, the tankards of the Pinte and Schnelle types are datable to between the second quarter and the end of the 16th century. Two fragments, however, one from each chute, belong to different times. Chute A contains a decorated fragment of a foliate band jug, datable to between 1520 and 1550 , while in chute $\mathrm{B}$ the base of a medallion jug from the second half of the 16th and the early 17th century was found. The maiolica objects from A are probably Antwerp products of the second half of the 16th century, while the fragments of an Italian fluted dish or crespina from chute B may belong to the last quarter of the 16th or the first quarter of the 17 th century.
On ceramological grounds the infill of both chutes dates from the second half of the 16th century. They both include pottery that is not earlier than 1550 (e.g. the Antwerp maiolica and the stoneware medallion jug). Although some items (e.g. the Italian fluted dish) point towards the beginning of the 17th century, the general composition is certainly not of an early 17 th-century date. On the basis of a few chronologically diagnostic ceramic fragments found in relatively small contexts containing abnormal assemblages (the jars and the stoneware), it is not possible to deduce a certain and precise chronology. For a sharper chronology, a combination of different data (historic, coins and other objects) will be considered in the synthesis.

The question must also be asked if the two chutes were filled at the same or at different times within this period. The Italian maiolica could be evidence that chute $\mathrm{B}$ was filled somewhat later than A, but their similar composition, in particular the number of albarelli, stoneware oil jugs and bird pots, argues in favour of simultaneous deposition.

Consideration of the forms may point to the identity of the users of the pottery. The Middelburg castle assemblages are not typical of a household, whether it is a castle, an abbey or a townhouse. The usual drinking vessels, jugs and pitchers in stoneware are missing, as are chamber pots in chute A. Elsewhere items like the oil jugs and bird pots are rare and gallipots are not known 
in these numbers. The redware forms related to food preparation dominate. Chute A contains 34 vessels for heating food, i.e. more than a third of the vessels found. As well, most of these are small skillets or double-handled jars. Larger pots capable of holding several litres are rare. Presumably the smaller skillets were used to hold individual portions of food. Paintings show that they were often used as eating utensils. ${ }^{52}$ The blackened bodies prove that they were placed on a fire. Chute B contained only five double-handled jars, of which only one was of a small volume, and one skillet. This may indicate a different pattern in either disposal or use.

The tableware reflects a normal typological composition, with some dishes and porringers glazed green inside and a few redware jugs. The two porringers with the Marian text are, however, unusual. The only example of such a porringer is known from a lay household in Bruges. The two two-handled Marian pots come from both lay and monastic contexts, the latter being a Wealthy Clares convent at Petegem in Flanders. Were those from the chute the possessions of the Poor Clares, who took shelter in the castle on several occasions, for instance in 1578-79, or were they looted from their or other nearby convents? But similar vessels have also been found in lay contexts. One could also ask why they were thrown away: because they were broken or because they communicated Catholic belief?

The limited number of stoneware drinking vessels and jugs found in the chutes and in other contexts excavated at the castle is striking. However, a low proportion of stoneware tableware is not that exceptional in this period, when glass drinking vessels were growing in popularity. ${ }^{53}$

The large number of gallipots is the most remarkable element of this assemblage. These jars were used to contain all kinds of ointments, greasy or oily semi-solid preparations, usually for medical purposes. They may have belonged to a dispensary, owned by a surgeon, doctor or pharmacist, and have been used to treat wounded soldiers. Another striking aspect of both assemblages is the presence of seven oil jugs, connected with spinning, also witnessed by the stoneware spindle whorl. As this is not considered a military activity, the Poor Clares come into the picture again. Spinning is a typical female activity that was also carried out in nunneries. ${ }^{54}$ Another explanation is that domestic spinning was carried out by the soldiers' wives or by servants living in the castle. But the large number of oil jugs points more in the direction of an organized group activity rather than to individual spinning.

\section{CONCLUSION}

The deposition of the pottery in both chutes was the result of a single operation or occurred within a very short period of time. This event can be dated in the second half of the 16th century or in the early 17 th century, but the assemblages mainly contain pottery of the second half of the 16th century. Both assemblages have a similar technological and typological composition. No direct links with the military occupation are apparent, although the large collection of gallipots may indicate a dispensary to treat soldiers at the turn of the century. The large number of small cooking pots and skillets may reflect a system or tradition in which individuals had to prepare their own meal and/or had to carry their own personal vessel. The porringers inscribed with religious texts and the stoneware related to spinning could be connected with the nuns who took refuge in the castle, although other interpretations, such as booty, are possible.

\section{THE VESSEL GLASS ${ }^{55}$}

\section{By DANIELLE CALUWÉ \\ QUANTIFICATION AND TAPHONOMY}

One of the main problems in the analysis and interpretation of archaeological vessel glass is the fragility of the material. This feature was an attractive characteristic, especially in combination with its transparency. Other features such as colour and plasticity, which allowed all sorts of designs and decorations, made vessel glass desirable in early modern times, and thus a good indicator of status and conspicuous consumption. On the other hand, its fragility can hinder archaeological quantification and identification.

The $1,559 \mathrm{~g}$ of glass from the chutes is made up of 345 fragments, representing a maximum of 74 individual vessels, 63 of which are typologically identifiable. Chute A yielded 35 vessels and four unidentifiable fragments, chute B 24 vessels and two unidentifiable fragments, and chute B's outflow six vessels and three fragments.

Bearing in mind that the material had been dumped in the chutes, the degree of fragmentation is relatively low: six forms are almost complete and 28 are base or foot fragments. Many vessels are broken into only a few pieces. As well as facilitating identification, this low degree of fragmentation may signify a rather short period of deposition, also shown by the fitting of pieces from different spits in the chutes and outflows. In chute B for instance, three colourless façon de Venise wall fragments were found within the chute and in its outflow. 
The assemblage is marked by a high degree of corrosion; only three colourless fragments, probably soda or partly soda glass, are unweathered. Five types of weathering were recognized, varying from opacity to heavy staining and rusty crumbling of the wall and bulk glass (Table 4, Condition). The corrosion of archaeological glass is a complex phenomenon caused by several factors such as the composition of the glass, soil conditions and the presence or the absence of ground water, creating specific microenvironments. Fifteenth- and 16th-century glass is particularly prone to corrosion, because its raw materials resulted in an unstable glass composition. The various compositions indicate the level of technological change and innovations typical of the craftsmen, methods, and materials in this period (Table 3, Glass type).

TABLE 3

Middelburg castle. Glass. Description of illustrated vessels, indicating probable glass type.

\begin{tabular}{lllll}
\hline Figure Chute & $\begin{array}{c}\text { Vessel } \\
\text { parts }\end{array}$ & Description & Form & Glass type
\end{tabular}

\begin{tabular}{|c|c|c|c|c|c|}
\hline Fig. 14:1 & A & 1 & Colourless plain pedestal beaker & Staple beaker & Mixed alkali \\
\hline Fig. 14:2 & A & 3 & Colourless façon de Venise tazza & Tazza & $\begin{array}{l}\text { Soda, mixed } \\
\text { alkali }\end{array}$ \\
\hline Fig. 14:3 & A & 3 & $\begin{array}{l}\text { Façon de Venise goblet with ribbed round } \\
\text { knop and fluted bowl }\end{array}$ & $\begin{array}{l}\text { Compound } \\
\text { goblet with } \\
\text { round knop }\end{array}$ & $\begin{array}{l}\text { Soda, mixed } \\
\text { alkali }\end{array}$ \\
\hline Fig. 14:4 & A & Undetermined & $\begin{array}{l}\text { Colourless façon de Venise tazza fragment } \\
\text { with nipt-diamond-waies pattern }\end{array}$ & Tazza & Soda \\
\hline Fig. 14:5 & A & 2 & Blue container base & $\begin{array}{l}\text { Blue container } \\
\text { or phial }\end{array}$ & Potash \\
\hline Fig. 14:6 & A & 2 & $\begin{array}{l}\text { Colourless façon de Venise beaker with } \\
\text { thick-cut trailing }\end{array}$ & $\begin{array}{l}\text { Meshwork } \\
\text { beaker }\end{array}$ & Mixed alkali \\
\hline Fig. 14:7 & A & 3 & Colourless goblet with round knop & $\begin{array}{l}\text { Goblet with } \\
\text { round knop }\end{array}$ & Mixed alkali \\
\hline Fig. 14:8 & A & 3 & $\begin{array}{l}\text { Colourless façon de Venice goblet with } \\
\text { round knop }\end{array}$ & $\begin{array}{l}\text { Goblet with } \\
\text { round knop }\end{array}$ & Soda \\
\hline Fig. 14:9 & A & Undetermined & $\begin{array}{l}\text { Colourless façon de Venice body fragment } \\
\text { in ice glass with parallel, horizontally } \\
\text { applied and tooled trails }\end{array}$ & $\begin{array}{l}\text { Ice-glass } \\
\text { fragment }\end{array}$ & Soda \\
\hline Fig. 14:10 & A & 2 & $\begin{array}{l}\text { Plain colourless cylindrical façon de Venise } \\
\text { beaker with ribbed foot ring }\end{array}$ & Plain beaker & $\begin{array}{l}\text { Soda or } \\
\text { mixed alkali }\end{array}$ \\
\hline Fig. 15:1 & B & 1 & Colourless squat beaker with vertical ribs & Squat beaker & Mixed alkali \\
\hline Fig. 15:2 & B & 1 & Neck fragment & Phial & Potash \\
\hline Fig. 15:3 & $\mathrm{B}$ & 1 & Colourless squat beaker with horizontal ribs & Squat beaker & Mixed alkali \\
\hline Fig. 15:4 & B & 1 & Colourless rim, hour-glass neck & Hour glass & Potash \\
\hline Fig. 15:5 & B & 2 & Cylindrical filigree beaker & Filigree beaker & Mixed alkali \\
\hline Fig. 15:6 & $\mathrm{B}$ & 2 & $\begin{array}{l}\text { Cylindrical façon de Venise beaker with } \\
\text { spiked gadroons }\end{array}$ & $\begin{array}{l}\text { Beaker with } \\
\text { spiked } \\
\text { gadroons }\end{array}$ & Mixed alkali \\
\hline Fig. 15:7 & $\mathrm{B}$ & 3 & Colourless round knop & $\begin{array}{l}\text { Goblet with } \\
\text { round knop }\end{array}$ & Mixed alkali \\
\hline Fig. 15:8 & B & 3 & $\begin{array}{l}\text { Colourless fragment of wound serpentine } \\
\text { stem }\end{array}$ & $\begin{array}{l}\text { Goblet with } \\
\text { serpentine } \\
\text { stem }\end{array}$ & Soda \\
\hline Fig. 15:9 & $\mathrm{B}$ & 1 & $\begin{array}{l}\text { White opaque wall fragment with ribbed } \\
\text { pattern, probably bowl }\end{array}$ & $\begin{array}{l}\text { White opaque } \\
\text { bowl }\end{array}$ & Mixed alkali \\
\hline Fig. 15:10 & $\begin{array}{l}\text { B } \\
\text { utflow }\end{array}$ & 2 & Green boot-beaker base & Boot beaker & Potash \\
\hline Fig. 15:11 & $\begin{array}{l}\text { B } \\
\text { utflow }\end{array}$ & 3 & Lion-mask stem & $\begin{array}{l}\text { Goblet with } \\
\text { lion mask stem }\end{array}$ & Soda \\
\hline
\end{tabular}




\section{TABLE 4}

Middelburg castle. Glass vessel condition, colour, function and decoration.

\begin{tabular}{lc}
\hline \multicolumn{2}{c}{ Middelburg castle glass } \\
\hline Condition & $\%$ \\
Unweathered & 4 \\
Opaque & 36 \\
Irization and white staining & 22 \\
Brown and grey decolouring & 7 \\
Rust & 1 \\
Heavily corroded & 30 \\
Colour groups & $\%$ \\
Blue & 1 \\
White & 1 \\
Colourless & 18 \\
Green & 22 \\
Façon de Venise & 58 \\
Functional groups & $\%$ \\
Drinking ware & 73 \\
Toasting & 5.5 \\
Table & 15 \\
Time measurement & 1 \\
Storage & 5.5 \\
Decorative groups & $\%$ \\
Undecorated & 47 \\
Applied & 5.5 \\
Moulded wall decoration & 35 \\
Filigree and Venetian techniques & 9.5 \\
Enamelled & 1 \\
Engraved & 1 \\
\hline &
\end{tabular}

\section{TYPOLOGY}

Chute A contains a wide range of luxury vessels from the mid- to the late 16th century and the first half of the 17th century. Typologically, the collection includes undecorated colourless forms such as the folded-foot beaker (Fig. 14:1), complex compound plain ones such as a unique, colourless façon de Venise tazza with a thin-walled, octagonal bowl (Fig. 14:2), a colourless façon de Venise goblet on a ribbed knob with the bowl decorated with a meshpattern (Fig. 14:3), and a colourless façon de Venise wall fragment of a tazza with a nipt-diamondwaies pattern (Fig. 14:4). These were associated with a base fragment in blue glass (Fig. 14:5), a wall fragment with thick cut trailing, probably from a chequered spiral trail beaker (Fig. 14:6) and a colourless façon de Venise undecorated goblet on a high foot with a round knop (Fig. 14:7). A third fragment originating from a goblet on a ribbed knop (Fig. 14:8), a wall fragment in ice glass (Fig. 14:9) and a colourless, plain cylindrical beaker (Fig. 14:10) come from less clearly defined contexts.

Chute B yielded an equally interesting range of luxury forms popular at the end of the 16th century and in the first half of the 17th century. Simple cylindrical forms such as the squat beaker with vertical ribs (Fig. 15:1), the neck of a small phial (Fig. 15:2), a colourless cylindrical beaker with horizontal ribs (Fig. 15:3), an hour glass (Fig. 15:4), a filigree beaker with applied prunts (Fig. 15:5), a beaker with spiked gadroons (Fig. 14:6) and an elongated ribbed knop in colourless glass (Fig. 15:7) all come from the same spit. The serpentine stem (Fig. 15:8) and the wall fragment in white opaque glass, probably from a bowl (Fig 15:9), belong to the first half of the 17th century. The small boot beaker (Fig. 15:10) and a lion mask stem (Fig. 15:11) were found in the outflow of chute $\mathrm{B}$.

\section{TECHNOLOGY}

All colour categories occur in both chutes (Tables 3-4, Colour groups), except for a fragment of high-quality blue glass in chute A (Fig 14:5) and one of high-quality white opaque glass in B (Fig. 15:9), which may indicate a slight chronological discrepancy between the chutes. The traditional green and colourless glass account for about a fifth of the assemblages (A: 22\%; B: $18 \%$ ). The remaining vessel glass was made à la façon de Venise, the luxurious, highly decorated style fashionable in the second half of the 16th and first half of the 17 th century. This colourless cristallo glass was most prized because of its transparency.

A second indicator of technological complexity is the way the vessels were formed. As a rule glass forms are initially based on a primary glass bubble or paraison, which is inflated, blown, and tooled to form a vessel. Under Venetian influence, the 16th century saw the introduction of vessels built up by assembling two and more glass paraisons, reflected by the relative increase in compound vessels in late 16th-century assemblages (Table 3, Vessel parts). ${ }^{56}$ The three vesselformation categories are present in both chutes in varying proportions with complex luxury shapes forming up to half of the assemblages (Table 5).

Over half $(53 \%)$ are also highly decorated. In addition to the primary hot-working techniques which range from overall mould-blown wall patterns to more elaborate filigree patterns, $2 \%$ of the decorated vessels also show post-formation decorative techniques such as enamelling and engraving (Table 4, Decorative groups). The undecorated 


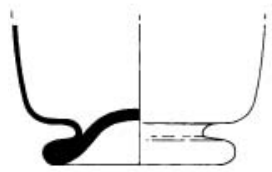

1

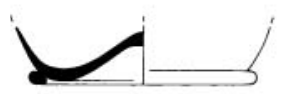

5

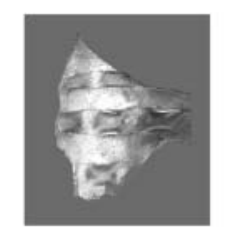

6

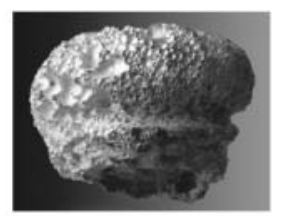

8

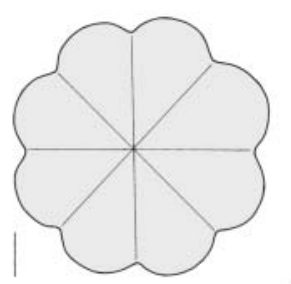

2
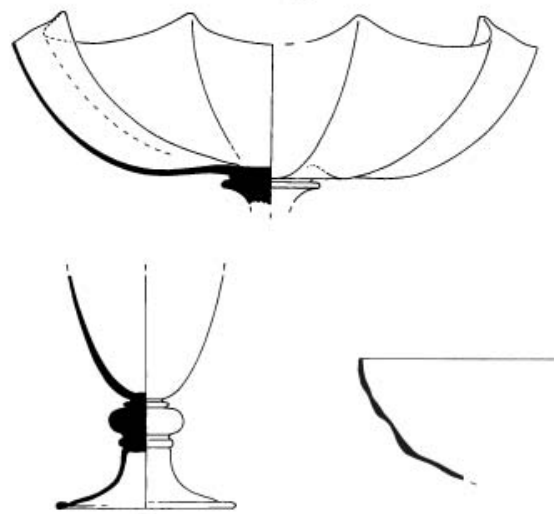

7

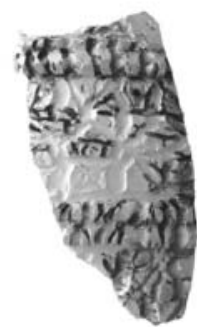

9

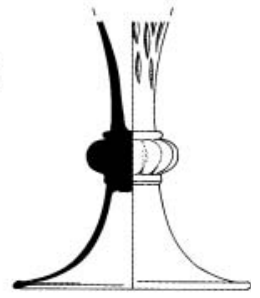

3

4
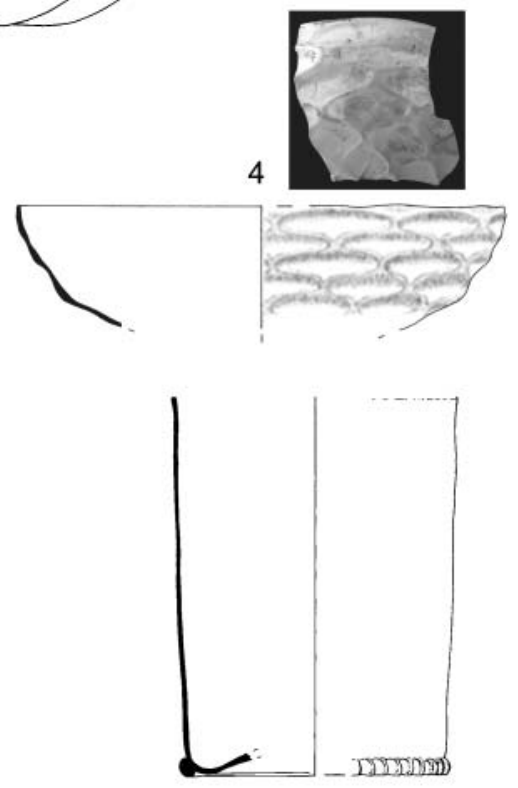

10

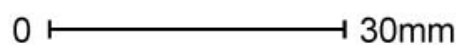

FIG. 14

Middelburg castle, chute A. Vessel glass: 1, 6, 10. beakers; 2, 4. tazze; 3, 7-8. goblets; 5. phial; 9. ice-glass body fragment. For more information, see Table 3.

half $(47 \%)$ indicates the increased importance of glass objects for daily use, storage and transport.

It can be argued that colouring with metal oxides constitutes the first level of decoration. The two objects made of coloured glass are a blue cylindrical base, probably from a small phial or bottle (Fig. 14:5), and a small ribbed wall fragment, perhaps from a white opaque bowl (Fig. 15:9). The latter illustrates the technological complexity of the Middelburg glass, as its decoration requires solutions on three levels: firstly in selecting the raw materials to colour the metal; secondly to render the glass opaque in the furnace; and thirdly to shape the vessel in a mould. Seventy two examples of this type of opaque glass, dating mainly from the 17th century, have been found in seven places in Belgium, the Netherlands and London. Bowls are the commonest (41 items). They were probably used on the table to hold expensive sweets, dried fruits and sweetmeats offered between courses. In the Low Countries, opaque white bowls are known from 17th-century contexts in Antwerp (Bogaerdenstraat, Stadsparking, Hopland), Breda (Catharinastraat, Kloosterkazerne, Molenstraat) and Ninove. ${ }^{57}$

Five vessels are blown in filigree glass, with prefabricated white opaque canes marvered into the colourless wall. Two types of filigree are 


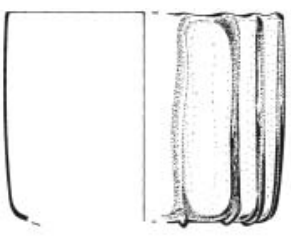

1

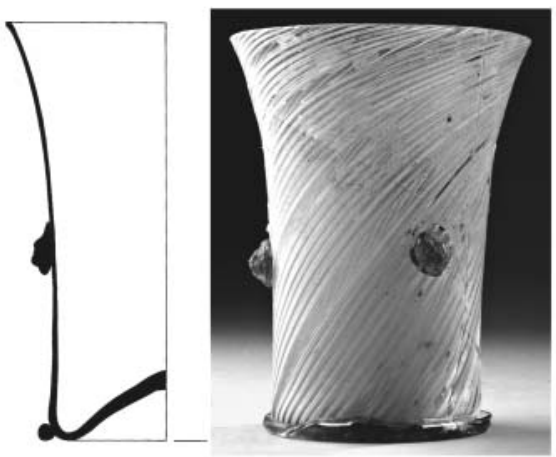

5

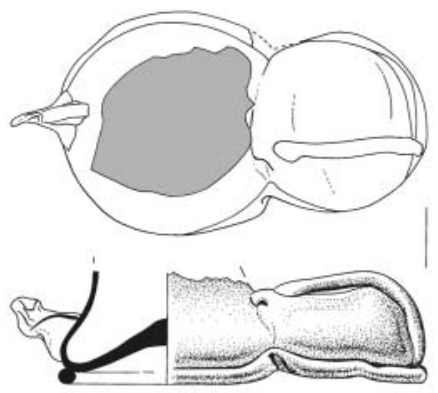

10

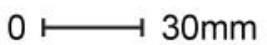

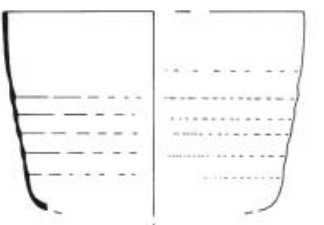

3

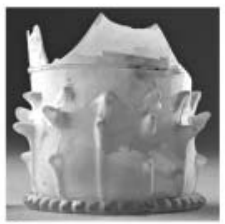

6

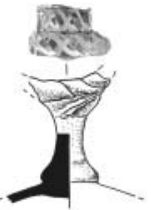

8

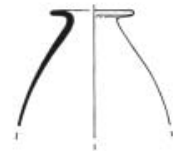

4

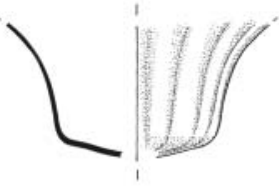

9
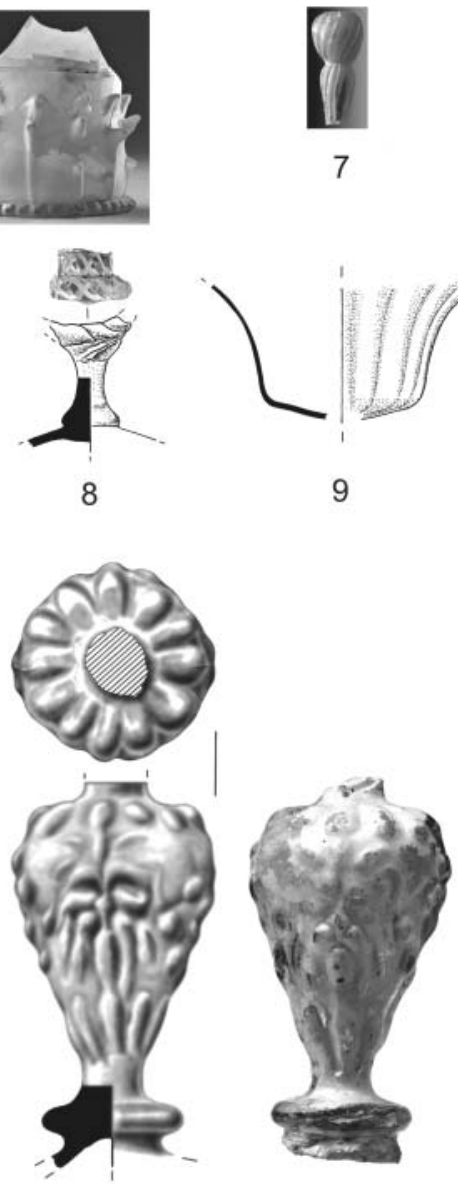

11

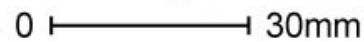

FIG. 15

Middelburg castle, chute B. Vessel glass: 1, 3, 5-6. beakers; 2. phial; 4. hour glass; 7-8, 11. goblets; 9. bowl; 10. boot beaker. For more information, see Table 3 .

distinguished by the pattern of the prefabricated canes: parallel (vetro a fili) and alternating clear and opaque twisted canes (vetro a retorti). Vetro a fili is used for a cylindrical beaker with a slightly everted rim (Fig. 15:5) and for two similar pedestal goblets with knops. As one of the latter came from each chute, it may indicate that the same material was used to fill both chutes at the same time; however, it may simply be related to the life-span of this type of goblet. Chute B also yielded a lid decorated with alternating opaque trails and vetro a retorti.

Other Venetian techniques include a wound serpentine cable stem with twisted, prefabricated white coloured canes (Fig 15:8), and a vessel in 
TABLE 5

Middelburg castle. Glass vessel formation.

\begin{tabular}{lcc}
\hline & $\begin{array}{c}\text { Chute A } \\
\%\end{array}$ & $\begin{array}{c}\text { Chute B } \\
\%\end{array}$ \\
\hline One-part vessels & 39 & 48 \\
Two-part vessels & 18 & 38 \\
Compound vessels & 43 & 21 \\
\hline
\end{tabular}

mezzo stampatura technique (Fig 15:6). In the latter case, the lower part of the beaker was dipped twice in the glass and formed in an optic mould, resulting in a thicker wall with pronounced vertical fluted ribs. These were tooled to form spiked gadroons. This kind of decoration was frequently applied to the lower part of beakers and bowls. In Brabant, examples of goblets have been found in late 16 th- to early 17 th-century contexts. ${ }^{58}$ Tyson mentions a bowl fragment with spiked gadroons of the same period from Narrow Street in London. ${ }^{59}$

One fragment made of colourless ice glass (Fig 14:9) may have been part of a conical bowl. The roughened aspect was obtained by cooling the paraison suddenly in water, resulting in an irregular pattern of fine cracks. The Middelburg wall fragment is also decorated with two parallel, horizontally applied ribbed threads. Ice glass is rarely found in the southern Netherlands. ${ }^{60} \mathrm{~A}$ few examples have been found in Antwerp: a cylindrical beaker with ribbed foot ring of the late 16th to early 17 th century from Raapstraat ${ }^{61}$ and fragments of a rather large bowl or plate of the late 16 th century from Kaasstraat; ${ }^{62}$ some small wall fragments from Steen ${ }^{63}$ and from Sudermanstraat ${ }^{64}$ consist of typologically unidentifiable ice-glass vessels of the late 16th to early 17 th century.

Only $5.5 \%$ of the decoration consists of monochrome applied and tooled threads and prunts. This is probably linked to the scarcity of prunted beakers in both chutes, where only three were recovered. They are common elsewhere in the Low Countries, ${ }^{65}$ as illustrated by the Antwerp Steen assemblage, which yielded more than 80 prunted beakers. ${ }^{66}$

The technological level of the Middelburg glass is also shown by the range of moulds used on $35 \%$ of the vessels. Cylindrical single-piece closed moulds were employed to apply patterns of ribs, bosses and meshwork on the wall and base of beakers (Fig 15:1, 3).

Two green beakers from chute A have an optic-blown wall pattern. These forms were rooted in the German tradition and occur frequently in contexts of the late 15 th and first half of the 16 th century. They indicate the presence of older material amongst the finds from chute A.

Chute B yielded a lion-mask baluster stem formed in a two-piece metal mould (Fig. 15:11). These forms are not uncommon and have been found in late 16th- to early 17 th-century contexts in Antwerp, ${ }^{67}$ Breda, ${ }^{68}$ 's Hertogenbosch ${ }^{69}$ and Brussels. ${ }^{70}$ Most are single finds, apart from an elite site in Brussels (Hof Van Hoogstraten of the end 16th and first half of the 17 th century) ${ }^{71}$ and an exceptionally rich, military, high-status context in Breda, dated to 1597-1604, with at least four lion-mask stems. ${ }^{72}$ In contrast they do not occur in Amsterdam, where applied prunts with lion masks were, it seems, more popular ${ }^{73}$ On the other hand in England at least 57 of 66 stems came from seven mould types, two of which matched a large number of stems and are thus most probably local products. ${ }^{74}$

The four vessels which combine hot and cold working techniques imply a high degree of technical expertise of one or more professional craftsmen.

Two fragments illustrate different techniques and different provenances. Both were enamelled, presumably whilst still hot. ${ }^{75}$ One wall fragment is typologically unidentifiable and heavily weathered; it has an angular shape and parallel traces of applied enamel threads. Colourless or lightcoloured pedestal beakers, generally of the Diablo type, with applied enamel threads, in some cases combined with small dots, are traditional early 16th-century products of the northern French and southern Belgian glass-producing region. ${ }^{76}$ Parallels come from 16th-century layers in Haarlem, ${ }^{77}$ Bruges, ${ }^{78}$ Antwerp (Bogaerdestraat) ${ }^{79}$ and Mechelen (Zoutwerf). ${ }^{80}$ Henkes mentions a late 16th-century French vessel from Besançon with similar decoration, but with a handle. ${ }^{81}$

The other enamelled rim fragment is unweathered; it may have been part of a cylindrical colourless beaker or a goblet and is decorated with white and blue lilies of the valley, considered a symbol of chastity. ${ }^{82}$ It is probably a 16 th-century Bohemian product. A similar fragment, datable to c. 1500, with floral decoration in green and yellow, was found at Sluis. ${ }^{83}$ Other parallels occur in Antwerp (Sudermantstraat) ${ }^{84}$ and in the house of a high-ranking soldier in Breda (1597-1604) ${ }^{85}$

Similar floral decoration on an enamelled wedding beaker bearing the portrait of a woman, found in Lunenburg and datable to the first half of the 17th century, is comparable to another beaker attributed to the Wilhelmsberger Hütte (Gratzen) ${ }^{86}$ Henkes mentions an enamelled beaker from the cesspit of an officer's lodging near 
Groningen, used from 1593 till 1640. ${ }^{87}$ The two women's portraits on the Groningen beaker are copies after Heinrich Voghtherr's pattern book, datable to the $1590 \mathrm{~s} .{ }^{88}$ The archaeological evidence seems to indicate that imports of enamelled vessels from Bohemia, possibly for wedding or betrothal purposes, are less exceptional than so far assumed. Their recurrent frequency in high-status military contexts like those in Middelburg, Groningen and Breda remains to be explained.

Engraved vessels like the tazza with inverted baluster are rare. Unfortunately, it is heavily fragmented and weathered and requires professional conservation before its design can be identified fully. Two vessels from a chute at's Hertogenbosch datable to the second half of the 16th century were engraved respectively with knights and the Seven Arts after a design of Virgil Solis (1514-62) ${ }^{89}$ Presumably these unique vessels were commissioned.

To conclude, the decorated glass recovered from the chutes is rich and varied, reflecting the whole range of techniques available at the time. A significant number of luxury vessels were decorated with Venetian techniques, some combining various hot and even cold techniques. They may have been commissioned or bought for a specific purpose. The purchase of such luxury ware was clearly intentional and reflects the status of their users.

\section{FUNCTION}

Apart from the unique hourglass from chute B (Fig. 15:4), the same functional groups occur in the two chutes. The assemblage is dominated by drinking vessels, which account for at least $73 \%$ of the whole (Table 4, Functional groups). 5.5\% of the vessel glass served more for toasting (Table 4; Figs $14: 4 ; 15: 11$ ) and another $15 \%$ consists of luxury tableware (Table 4; Figs 14:2, 4; 15:9). The remaining $5.5 \%$ of the vessel glass consists of utilitarian objects used for storage, including two jars (Table 4). A high proportion of drinking vessels and tableware have been shown in England to be typical of 16th-century elite assemblages. ${ }^{90}$

Both chute fills contain luxury filigree goblets and other façon de Venise vessels, but chute B and its outflow yielded a significant set related to feasting and toasting, including a façon de Venise lid, a lion-mask stem, three filigree goblets and two beakers, and also a small boot beaker. Apart from green vessels for everyday use, there are two in the form of a man's boot (Fig. 15:10). ${ }^{91}$ Several late 16th-century and early 17 th-century colourless façon de Venise vessels in the form of high riding boots are known in museum collections in Brussels, Liège, Vienna, Berlin, ${ }^{92}$ Cologne ${ }^{93}$ and Hanover, ${ }^{94}$ but smaller types in green glass are less frequently reported. A green boot goblet was found in a 16th-century context in 's Hertogenbosch (Postelstraat), ${ }^{95}$ Strasbourg ${ }^{96}$ and Bergen (Norway). ${ }^{97}$ These small goblets in the German forest-glass tradition were blown locally, as suggested by a small fragment from a late 16thcentury glasshouse at Woodchester in Gloucestershire. ${ }^{98}$ Dreier places the production of colourless luxury façon de Venise boot vessels in 16th-century Venice, explaining their particular form as traditional and apotropaic and drawing attention to their use as friendship beakers in convivial settings. ${ }^{99}$ Their presence in military surroundings, such as Middelburg castle, is shown by another type of façon de Venise drinking beaker in the form of a cannon found in a high-ranking officer's dwelling in Breda of the same period (1594-1604). ${ }^{100}$ The use of drinking vessels with specific forms and names in elite military circles is also attested by the façon de Venise drinkuit (literally drink-up or stir-up beaker) and beakers in the form of a table bell, called Ducdalf after the Duke of Alva, one the commanders of the Spanish army in the Low Countries. ${ }^{101}$ Such vessels occur in both museum collections ${ }^{102}$ and archaeological contexts, ${ }^{103}$ and were mentioned in historical records and inventories. ${ }^{104}$ Their use is attested by documentary and iconographical evidence related to a special dinner held in 1581 to celebrate the victory of the Dutch over the Spanish troops. ${ }^{105}$ This wide range of evidence points to the frequency and the importance of particular vessels in high-ranking military contexts.

\section{FREQUENCIES}

Table 6 lists 21 types, of which just over half are represented by two or more items. It also shows where they have been made - either locally in the Low Countries or in Germany, Bohemia and France. The assessment of their frequency in Brabant and Flanders is derived from an ongoing study. ${ }^{106}$ Although such assessments are subjective and depend on excavations and publications, the estimates serve to place the assemblage in its regional and international context. Each chute contains four of the five frequency definitions. Their relative frequency and the rarities highlight the high status of the Middelburg assemblage.

\section{CONCLUSION}

A rich and varied range of glass consisting of both utilitarian and luxury vessels were recovered from the chutes. The high proportion of drinking and table glass indicates convivial drinking. The 
TABLE 6

Middelburg castle. Glass vessel chronology, provenance and frequency (using frequency definitions as introduced by Willmott 2002, 35).

\begin{tabular}{|c|c|c|c|c|c|}
\hline Chute & Type & MNV & $\begin{array}{l}\text { Period in } \\
\text { use }\end{array}$ & Probable provenance & $\begin{array}{l}\text { Frequency in } \\
\text { Brabantine and } \\
\text { Flemish sites }\end{array}$ \\
\hline A & $\begin{array}{l}\text { Enamelled cylindrical beaker } \\
\text { with fleur-de-lis motif }\end{array}$ & 1 & $16-17 \mathrm{~A}$ & Bohemia & Very rare \\
\hline $\mathbf{A}$ & Pedestal beaker & 2 & $16 \mathrm{~A}$ & $\begin{array}{l}\text { Low Countries, Antwerp, } \\
\text { France }\end{array}$ & Quite common \\
\hline $\mathbf{A}$ & Beaker with wrythen ribs & 2 & $15 \mathrm{~d}-16 \mathrm{~A}$ & $\begin{array}{l}\text { Low Countries, Hainaut, } \\
\text { Walloon Brabant }\end{array}$ & Very common \\
\hline $\mathbf{A}$ & $\begin{array}{l}\text { Wide bowl with almost } \\
\text { angular ribs, compound form }\end{array}$ & 1 & $16 \mathrm{~d}$ & Antwerp & Very rare \\
\hline A & $\begin{array}{l}\text { Cylindrical beaker with thick } \\
\text { cut trailing }\end{array}$ & 2 & $16 \mathrm{~b}-17 \mathrm{~A}$ & $\begin{array}{l}\text { Germany, Spessart, Low } \\
\text { Countries, Antwerp }\end{array}$ & Quite common \\
\hline A & $\begin{array}{l}\text { Engraved tazza with elongated } \\
\text { baluster }\end{array}$ & 1 & $16 \mathrm{~B}-17 \mathrm{a}$ & Low Countries, Antwerp & Very rare \\
\hline A & Ice glass & 1 & $16 \mathrm{~d}-17 \mathrm{~A}$ & Low Countries, Antwerp & Rare \\
\hline B & $\begin{array}{l}\text { Squat beaker with vertical or } \\
\text { horizontal ribs }\end{array}$ & 2 & 17 & Low Countries, Antwerp & Very common \\
\hline B & Hour glass & 1 & $16-17 \mathrm{~A}$ & Low Countries, Germany & Uncommon \\
\hline B & Serpentine stem & 1 & 17 & Low Countries, Antwerp & Quite common \\
\hline B & Opaque white bowl & 1 & $17 \mathrm{~A}$ & Low Countries, Antwerp & Uncommon \\
\hline B & $\begin{array}{l}\text { Lid with nipt filigree } \\
\text { decoration }\end{array}$ & 1 & $16 \mathrm{~d}-17 \mathrm{a}$ & Low Countries, Antwerp & Very uncommon \\
\hline B & $\begin{array}{l}\text { Small beaker in the form of a } \\
\text { boot }\end{array}$ & 1 & $16 \mathrm{~d}-17 \mathrm{~A}$ & Germany and Low Countries & Very rare \\
\hline B & $\begin{array}{l}\text { Pedestal beaker with angular } \\
\text { bowl and applied enamel trails }\end{array}$ & 1 & $15 \mathrm{~d}-16 \mathrm{~A}$ & Lorraine & Rare \\
\hline$A \& B$ & Plain cylindrical beaker & 4 & $16-17$ & $\begin{array}{l}\text { Low Countries, Antwerp, } \\
\text { Germany }\end{array}$ & Very common \\
\hline$A \& B$ & $\begin{array}{l}\text { Low cylindrical beaker; staple } \\
\text { beaker }\end{array}$ & 2 & 17 & Low Countries, Germany & Quite common \\
\hline$A \& B$ & Plain cylindrical jar & 2 & $17 \mathrm{~A}$ & $\begin{array}{l}\text { Low Countries, Hainaut, } \\
\text { Brabant }\end{array}$ & Uncommon \\
\hline$A \& B$ & $\begin{array}{l}\text { Goblet with ribbed round } \\
\text { knop }\end{array}$ & 8 & $16 \mathrm{~d}-17 \mathrm{a}$ & Low Countries, Antwerp & Quite common \\
\hline$A \& B$ & $\begin{array}{l}\text { Beakers with pulled prunts, } \\
\text { Berkenmeier type }\end{array}$ & 3 & $16 \mathrm{~B}$ & Low Countries, Germany & Very common \\
\hline$A \& B$ & Cylindrical beaker with bosses & 6 & $16-17$ & $\begin{array}{l}\text { Hainaut, North France, } \\
\text { Low Countries }\end{array}$ & Very common \\
\hline$A \& B$ & $\begin{array}{l}\text { Knopped-stem goblet in } \\
\text { filigree glass }\end{array}$ & 2 & $16 \mathrm{~d}$ & $\begin{array}{l}\text { Antwerp, Beauwelz, Low } \\
\text { Countries }\end{array}$ & Uncommon \\
\hline
\end{tabular}

MNV = Minimum Number of Vessels.

Period in use. $16=16$ th century; $17=17$ th century; $A=1$ st half; $B=2$ nd half; $a=1$ st quarter; $b=2$ nd quarter; $c=3 r d$ quarter; $\mathrm{d}=4$ th quarter.

octagonal (Fig. 14:2) and engraved tazze and the boot beaker are unusual and reflect elite military status. The finds record a key moment in glass production and consumption in Flanders, and provide some insight into the spread of technical innovation, representing the transition from traditional glass to modern façon de Venise. ${ }^{107}$

Most of the glass can be dated to the last decades of the 16th century and to the early 17 th century. It was probably deposited over a rather 
short period of time. The chutes are very close in date. The oldest forms of the late 15 th to the first half of the 16th century come from chute A and were found with more recent types. Chute B contained more early 17th-century ones suggesting a slightly later deposition date. However, their scarcity and particular social use may explain their absence from the other chute.

\section{WINDOW GLASS}

\section{By HILDE WOUTERS}

\section{INTRODUCTION}

As no contemporary descriptions and reliable pictures of the castle survive, the window glass found in both chutes is the only record of the fenestration of the castle in the 15 th and 16th century. ${ }^{108}$

\section{QUANTIFICATION}

Archaeological window glass is characterized by a high level of fragmentation, often providing little information on the original shape of the pane or the glass panel from which it came. Consequently, a quantification method based on the estimated surface represented by the total amount of fragments was adopted.

Fragments of window glass were matched between several spits in each chute. The assemblage consists of various small shards and even some complete pieces of glass. The number of window-glass fragments found in both chutes totals 588, 102 fragments from chute A and 486 from chute B. The higher number from chute B is perhaps linked to the larger volume of the chute and its superstructure or to the nature and taphonomy of the fill. The excavated window glass would cover $507,000 \mathrm{~mm}^{2}\left(126,700 \mathrm{~mm}^{2}\right.$ in chute A and $380,200 \mathrm{~mm}^{2}$ in chute B). As the surface of an average window pane of $800 \mathrm{~mm}$ to $400 \mathrm{~mm}^{109}$ amounts to $320,000 \mathrm{~mm}^{2}$, the total amount found in both chutes is equivalent to one and a half window panes, i.e. only a small proportion of that required to glaze even one room in the castle.

\section{TECHNOLOGY, TYPOLOGY AND TAPHONOMY}

All fragments were made in a colourless glass with a greenish tint, the most common glass fabric in contemporary assemblages. ${ }^{110}$ Two types of plain
1

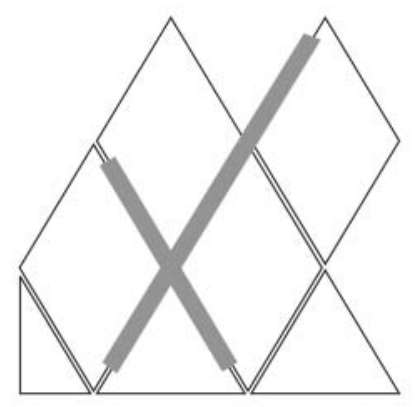

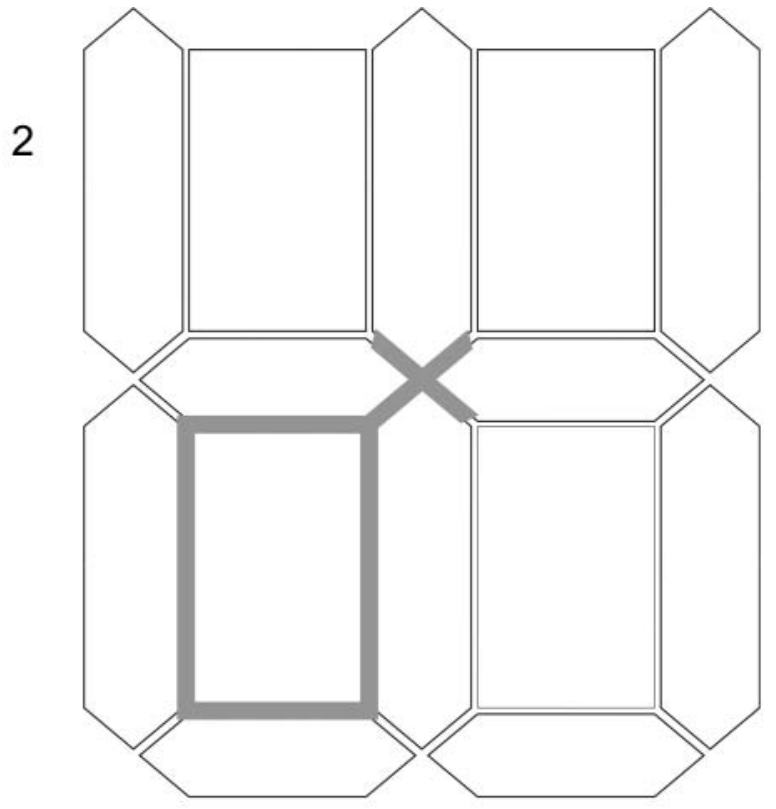

$200 \mathrm{~mm}$

FIG. 16

Middelburg castle. Window glass: 1 . lozenge-style; 2 . Flemish Renaissance style. 
window fenestration can be recognized in both chutes, the 'lozenge-type' (Fig. 16:1) and the Flemish Renaissance style (Fig. 16:2). ${ }^{111}$ The former is at least $3 \mathrm{~mm}$ thick, whereas the latter is not more than $2 \mathrm{~mm}$ thick. The Middelburg lozenge-type fragments were it seems mainly produced by the crown-glass method. ${ }^{112}$ The firerounded edges on a few shards show that the Flemish Renaissance-type pieces were made with the cylinder or muff method. ${ }^{113}$

The size of the rhomboid pieces from chute A varies from $67 / 71$ by $91 / 100 \mathrm{~mm}$. Their edges had been shaped by nibbling (i.e. by cutting with a grozing iron). They came from one or more lozenge-type windows. Similar pieces from chute B exhibit a wider variety of sizes from the smallest about 73 by $91 \mathrm{~mm}$, similar to those in chute A, to the larger $83 / 95$ by $91 / 123 \mathrm{~mm}$. Several fragments had been nibbled and six others had been cut with a diamond. The latter must have been shaped after diamond cutting was introduced in the 16th century. ${ }^{114}$

The only fragment of stained glass found is decorated with a figurative design, one of whose eye and animal ear remains. ${ }^{115}$ It is 16 th-century in style.

Although entire panes were not found, 33 rhomboid or parallel-sided fragments are complete enough to show that they originally formed part of diamond quarries set in a lead lattice. ${ }^{116}$ The relatively high number of entire, or almost so, pieces, ${ }^{117}$ found in both chutes, is uncommon and indicates that this fragile material must have been thrown into the chutes shortly after its removal from the windows.

\section{CHRONOLOGY}

The material from the Middelburg chutes comes from more than one type of plain and stained window which may have been made at different times. However, establishing a chronology based on window glass is a challenge. ${ }^{118}$ Less window than vessel glass is usually found in archaeological contexts. In order to keep the window waterand wind-tight, the glass had to be regularly maintained in situ by releading the existing panes and by replacing broken ones. ${ }^{119}$ Window glass was often removed for reuse elsewhere. ${ }^{120}$ As a result it was rarely discarded and that which was would be a mix of old and new panes.

Precise dating of window glass by form is hazardous. However, lozenge-type glass is most commonly found in association with bull's-eye panes in 15th-century contexts, while from about 1550 and during the 17th century the Flemish Renaissance-type of plain glazing spread. ${ }^{121}$ The association of older lozenge types with later Flemish Renaissance glass does not contradict this chronology since older windows (or parts of them) still could have been in use (or had been reused) and because the lozenge type was still made in the 16th century. For these reasons the Middelburg assemblage may be dated to the latter part of the 16 th century.

\section{CONCLUSION}

Lozenge panes of different sizes and thicknesses were in use in the castle at the same time. ${ }^{122}$ Probably at least seven fragments of lozenge windows originate from the first construction phases of the castle in the 15th century and remained in use or were reused. ${ }^{123}$ The other lozenge-type pieces and the fifteen or more quarries of Flemish Renaissance type are probably later and belong to the 16 th century. The discard of relatively intact window glass suggests that some of the castle's windows were either partly broken, removed or in the process of being replaced when the garderobe chutes were filled.

\section{BUILDING MATERIALS}

\section{By WIM DE CLERCQ}

\section{STOVE TILES}

Various stove tiles were found in both the chutes and the castle moat. These niche-like, semitubular pieces were part of late-medieval heating systems introduced from central and eastern Europe ${ }^{124}$ and used after the mid-15th century in elite Flemish houses in Ghent and Bruges. The stoves were placed in the centre of important rooms, for instance in audience and dining halls where the lord met his guests. Because of the semi-public nature of these spaces, heraldic symbols and emblems of the lord and his allies were displayed on or near the stove. ${ }^{125}$

Chute A yielded a fragment made in a red fabric (identical to the local redware pottery), covered with a green glaze and decorated with a leaf (Fig. 10:84). The complete square tiles found in the castle moat were decorated with similar floral motifs typical of 16th-century stove decoration. ${ }^{126}$ An almost complete stove tile depicting the Burgundian quatrefoil from chute B (Fig. 13:114) was made in the same red fabric, but covered outside with a thick yellow glaze. Its type and decorative pattern were common from the mid-15th to the mid-16th century. ${ }^{127}$ The greenglazed ribbed pilasters decorated with a fleur-de-lis probably once decorated the corners of stoves or fireplaces. ${ }^{128}$ The features from which they came 
were presumably dismantled when or just before the chutes and the moat were filled.

\section{BRICK AND SLATE}

The chute-use deposits were covered with a thick layer of building material, consisting of bricks, decayed beams, large mortar lumps and slate fragments from the destruction of the chutes' superstructure and hence of this part of the castle. The bricks $(c .220 \times 110 \times 50 \mathrm{~mm})$ were made of a coarse yellowish clay, probably from local Holocene marine deposits.

The rectangular slabs of slate measured about 220 by $140 \mathrm{~mm}$. A few bore up to four small nail-holes. They had been used to cover the roof.

\section{CONCLUSION}

The presence of an almost complete stove tile, pilaster fragments and other building materials in the chutes may indicate that parts of the castle were being destroyed while or just before the garderobes were in use. The heavier building debris could have sunk down later.

\section{COINS AND JETTONS}

\section{By FRANS DE BUYSER}

One coin from the reign of King Philip II (1555-98, possibly minted 1557-67) and two jettons datable to the 16 th century were found in the chutes. The coin provides a terminus post quem for the filling of chute A.

\section{Chute A, spit 24}

Coin: Spanish Low Countries — Philip II 155598.

Type 'Korte' — no further identification (1557$67)^{129}$

Copper; $0.94 \mathrm{~g} ; 18.5 \mathrm{~mm}$. Die axis? — badly preserved

Obverse: Traces of a head facing right Legend: [ ]

Reverse: Traces of fire-steels

\section{Chute A, spit 28}

Jetton: NUREMBERG - ship penny; end 15th to second half 16 th century ${ }^{130}$

Yellow copper; $1.22 \mathrm{~g} ; 29 \mathrm{~mm} .30^{\circ}$ — badly preserved, affected by iron corrosion

Obverse: Ship on the waves

$$
\text { Legend: ]OVI }
$$

Reverse: Four fleur-de-lis in cross form; set in a double rhomb

$$
\text { Legend: JOV (crown) }
$$

Chute B, spit 33

Jetton: NUREMBERG - Reichsapfel type ${ }^{131}$

Anonymous; end 15 th to 2 nd half 16 th century fictive legend

Yellow copper; $0.91 \mathrm{~g} ; 24.5 \mathrm{~mm} .180^{\circ}$ - well preserved

Obverse: A rose at the centre encircled by three fleurs-de-lis and three crowns

Reverse: Orb

$$
\text { Legend: VENIOB:VENOIBI:VENOI }
$$

Legend: (crown) VOBI [ ] ONB:VOND:

VOND

\section{METAL OBJECTS}

\section{By STEPHANE VANDENBERGHE and WIM DE CLERCQ}

\section{CHUTE A}

Apart from lead shot, the coin and the jetton, only two metal objects were found in this structure. The first is a thin, copper-alloy plate of unknown function with two preserved, slightly bevelled corners (Fig. 17:1). It shows eight intentional perforations and a rivet which points to it originally having been attached to another object (of wood?). The second find is a copper-alloy nail or stud with a flattened head (Fig. 17:2). Similar studs were found in a Civil-War ditch at Acton Court. ${ }^{132}$ They occur on contemporary furniture such as chests, boxes, and chairs.

\section{CHUTE B}

Chute B yielded fourteen metal objects. A long perforated iron plate (Fig. 17:3) could have been attached to furniture, a hatch or some other construction made of boards. Two small copper-alloy buckles (Fig. 17:4-5) probably belonged to shoes. Another clothing accessory is a small copper-alloy button (Fig. 17:6). A fragment of a copper-alloy belt fastener (Fig. 17:7) bears the letters 'I . . . S', originally reading 'IHS', the sacred trigram for JESUS in Greek. ${ }^{133}$ Similar monograms are common on 16th-century clothing, bandoliers and books clasps. ${ }^{134}$ An almost complete (cast?) copper-alloy thimble with a rectangular hole and regular dent in the top (Fig. 17:8) could have been be used for sewing, although the later perforation and dent may point to an unknown secondary function. A small perforated lead disc (Fig. 17:9) may have been a spindle whorl. The purpose of the last two copper-alloy objects (Fig. 17: 10-11) is uncertain. One intentionally perforated and decorated with a shell-like design could be a dagger knuckle guard or quillion. 

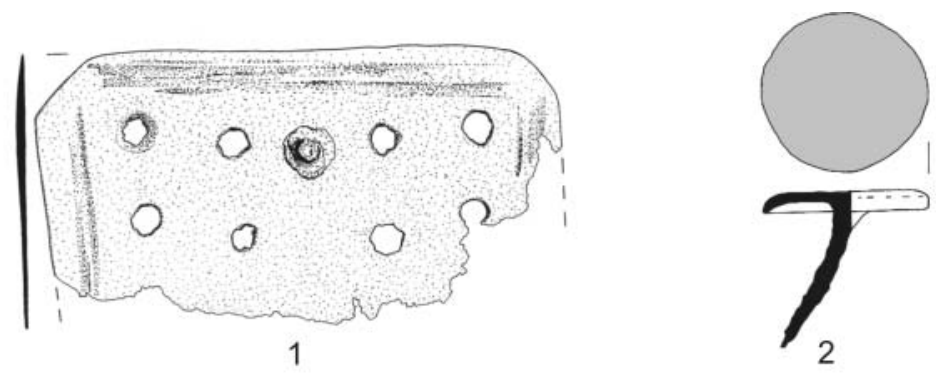

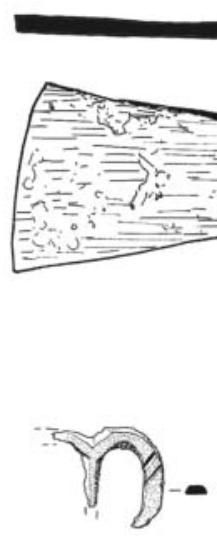

4

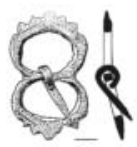

5

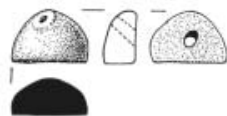

6

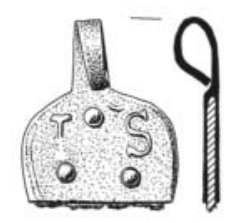

7

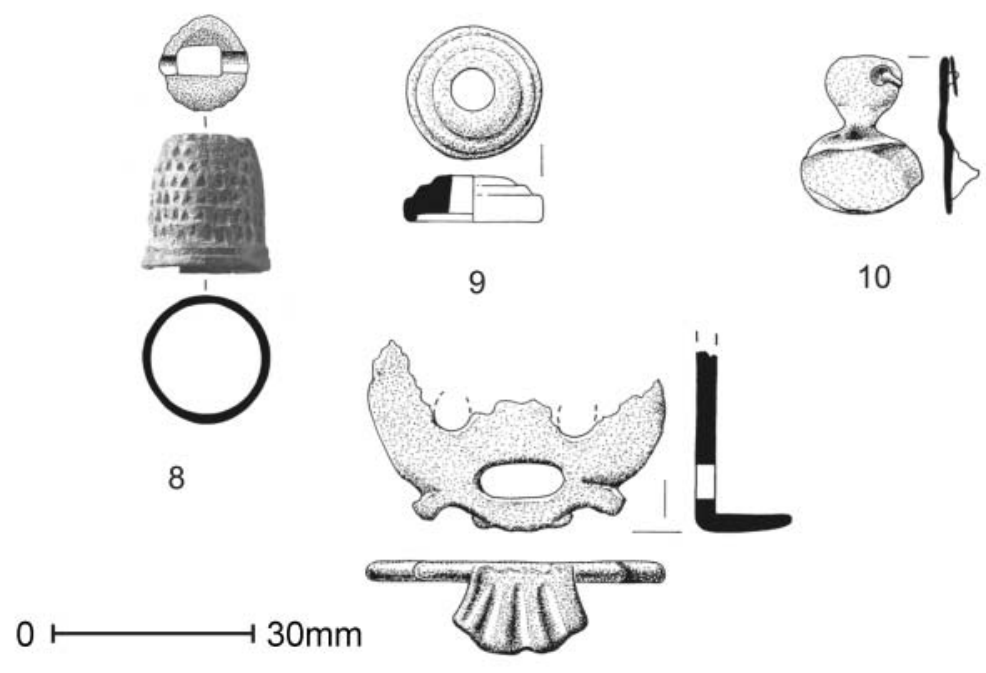

11

FIG. 17

Middelburg castle. Metal objects, chute A: 1. plate; 2. nail or stud. Chute B: 3. plate; 4-5. buckles; 6. button; 7. belt fastener; 8. thimble; 9. disc; 10. unidentified function; 11. ?quillion. Copper-alloy, except 3. iron; 9. lead. 
As well as these fittings, a remarkable set of five intact miniature objects in lead-tin alloy seem to have been thrown deliberately into the chute, where they were found near its bottom and in the outflow into the moat. It consists of an incense burner, a chalice, a candleholder, a holy-water stoup or bucket and a paten (Fig. 18:1-5). The first three were finely decorated with wavy lines. Similar finds are known from Amsterdam, Rotterdam, Nieuwlande, Middelburg in the Netherlands and
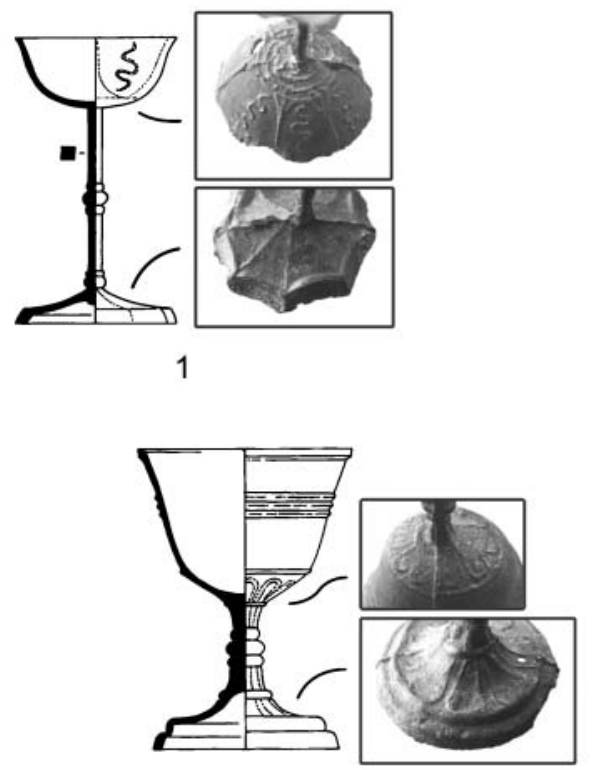

3

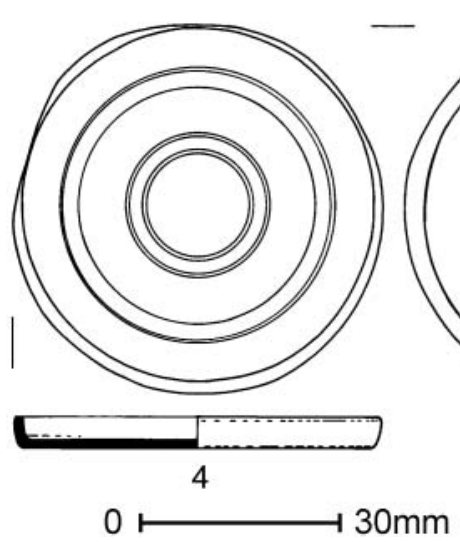

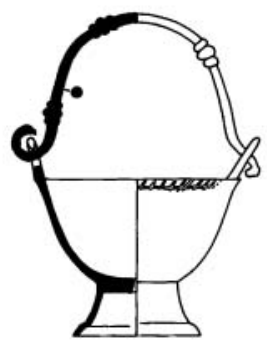

5

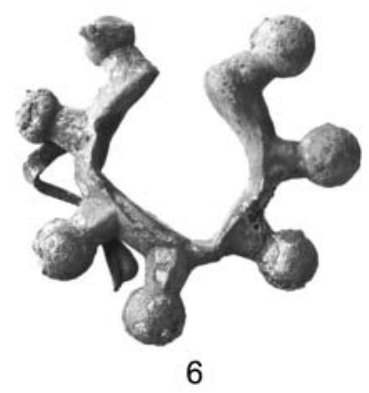

0 $30 \mathrm{~mm}$

FIG. 18

Middelburg castle. Metal objects, chute B. Lead-tin sacramentillos or religious toys: 1. incense burner; 2. candleholder; 3. chalice; 4. holy-water stoup; 5. paten. 6. Lead cast header with uncut shot. 
account of the Inquisition on Canary Island, where the humanist Livinius Apollonius from Middelburg-in-Flanders had fled from the Wars of Religion. ${ }^{139}$ Brought to trial in the $1580 \mathrm{~s}$, he testified in court how religion was practised in his homeland, describing how children played with sacramentillos (little sacraments), toys 'high as a thumb and made of lead' and miniature monstrances on 'small altars decorated with incense burners'. ${ }^{140} \mathrm{He}$ was supported by three Flemish merchants, who attested that in Flanders parents bought for their children cheap menudencias, small tin or lead toys imitating altars. ${ }^{141}$

\section{CONCLUSION}

Most of the fragmentary metal objects presumably once belonged to clothing and furniture. The set of five intact late 16th-century toys seems to have been deliberately thrown away, not because they were damaged, but probably because they symbolized Catholic ritual practice.

\section{LEAD SHOT}

\section{$B y$ WIM DE CLERCQ and PEDRO PYPE}

The chutes contained lead shot and finished projectiles, as well as half-finished products and cast waste. The seam on the pieces and the headers show that the shot was cast in two-piece moulds. The waste comprises headers with uncut shot, shot with attached casting sprues and waste headers. In chute A, four bullets (one of $11 \mathrm{~mm}$, two of $12 \mathrm{~mm}$ and one of $14 \mathrm{~mm}$ calibre) were found, all unfinished since the runners had not been cut off. In addition to the lead shot, a fragment of a waste header with casting sprues attached for at least four bullets was found. Chute B yielded thirteen of these items (seven of $6 \mathrm{~mm}$, one of $10 \mathrm{~mm}$, two of $12 \mathrm{~mm}$, one of $15 \mathrm{~mm}$ and two of $16.5 \mathrm{~mm}$ calibre). Two were perfectly finished but unused; one has impact traces. The remaining bullets were halffinished and the seven of the $6 \mathrm{~mm}$ type had not yet been cut from the cast header (Fig. 18:6). Judging from the calibre, the lead projectiles could have been used in pistols and in heavier guns, such as harquebuses, calivers and muskets.

Several hundred half-finished shot, many powder holders and even a multiple cast-mould for the production of 59 bullets of two different calibres were found in other parts of the site, particularly near the gate and towers, ${ }^{142}$ showing that the soldiers made lead shot in the castle itself, presumably at the time of the filling of the chutes or just before.
THE ANIMAL REMAINS ${ }^{143}$

\section{By AN LENTACKER, WIM VAN NEER and ANTON ERVYNCK}

\section{INTRODUCTION}

Most of the animal finds were recovered from the chutes by sampling. The rest of the fill and outflow were dug by hand, resulting in a bias towards larger finds. The samples were wet-sieved using minimum mesh widths of $0.5 \mathrm{~mm}$. After sieving, the residue was dried and sorted into three fractions according to size: larger than $5 \mathrm{~mm}$, between 5 and $2.5 \mathrm{~mm}$, and between 2.5 and $0.5 \mathrm{~mm}$. The hand-collected material and the sieved fractions larger than $5 \mathrm{~mm}$ were studied. Of the smaller fractions, only a sub-sample of the fish remains was examined.

\section{CHUTE A: INVENTORY AND TAPHONOMY}

As the analysis of the ceramics and the glass finds demonstrated that fragments of artefacts derived from all depths within the fill of the chute could be fitted together, the animal remains were treated as a whole (Table 7). The hand-collected finds were not plentiful and mainly comprised mammal bones. Cattle emerged as the dominant species, without doubt because collecting by hand favours larger finds. Indeed, a closer look at the greater than $5 \mathrm{~mm}$ fraction revealed that smaller livestock was not uncommon. A significant number of pig remains were identified, whilst an even larger number of bones could be grouped under the label 'sheep and goat'. Given their morphological similarity, most of the skeletal elements of these two species cannot confidently be distinguished. ${ }^{144}$ However, when it was possible to make a positive identification, the species invariably turned out to be sheep.

Skeletal elements from all parts of cattle, pig and 'sheep and goat' were found. Most of the pig bones came from young animals (typical of medieval archaeological assemblages because pigs do not yield any secondary products). Some of the cattle bones were of young animals less than three and a half years old. The age of the sheep and goat remains could hardly be estimated. The bones of the larger domesticates must represent human consumption refuse, corroborated by their fragmentation and the presence of butchery marks.

The wild mammals, represented only in the $>5 \mathrm{~mm}$ fraction, consist mainly of small species, i.e. rodents, a bat species and the mole. As they are unlikely to have been eaten, they presumably entered the chute when it was in use or soon after. Once decomposed, their bones were probably distributed throughout the fill by post-depositional disturbances. ${ }^{145}$ The hare and the rabbit were 
TABLE 7

Middelburg castle. Animal remains (excluding fish): number of specimens.

\begin{tabular}{|c|c|c|c|c|}
\hline & $\begin{array}{c}\text { Chute A } \\
\text { HC }\end{array}$ & $\begin{array}{c}\text { Chute A } \\
5 \mathrm{~mm}\end{array}$ & $\begin{array}{c}\text { Chute B } \\
\text { HC }\end{array}$ & $\begin{array}{c}\text { Chute B } \\
5 \mathrm{~mm}\end{array}$ \\
\hline \multicolumn{5}{|l|}{ Freshwater molluscs } \\
\hline Common valve snail (Valvata piscinalis) & - & - & - & 171 \\
\hline Laver spire shell (Hydrobia ulvae) & - & - & - & 1 \\
\hline Common bithynia (Bithynia tentaculata) & - & 11 & - & 150 \\
\hline Leach’s bithynia (Bithynia leachii) & - & - & - & 50 \\
\hline Marsh snail (Lymnaea palustris) & - & 1 & - & - \\
\hline Eared pond snail (Lymnaea auricularia) & - & - & - & 2 \\
\hline Wandering pond snail (Lymnaea ovata) & - & 17 & - & 51 \\
\hline Pond snail (Lymnaea sp.) & - & - & - & 625 \\
\hline Ramshorn snail (Planorbis planorbis) & - & - & - & 19 \\
\hline Whirlpool ramshorn snail (Planorbis vortex) & - & - & - & 3 \\
\hline Anisus albus & - & - & - & 15 \\
\hline Anisus sp. & - & - & - & 1 \\
\hline Amber snail (Succinea putris) & - & - & - & 4 \\
\hline \multicolumn{5}{|l|}{ Land snails } \\
\hline Glossy pillar (Cochlicopa lubrica) & - & - & - & 9 \\
\hline Door snails (Clausiliidae sp.) & - & - & - & 5 \\
\hline Rounded snail (Discus rotundatus) & - & 23 & - & - \\
\hline Dark-bodied glass snail (Oxychilus draparnaudi) & - & 27 & - & - \\
\hline Oxychilus sp. & - & - & - & 10 \\
\hline Keelback slugs (Limacidae sp.) & - & - & - & 1 \\
\hline Hairy snail (Trichia hispida) & - & - & - & 21 \\
\hline Banded wood snail (Cepaea nemoralis) & - & 1 & - & - \\
\hline Brown garden snail (Helix aspersa) & - & 8 & - & 1 \\
\hline \multicolumn{5}{|l|}{ Marine molluscs } \\
\hline Common mussel (Mytilus edulis) & - & 244 & 124 & 197 \\
\hline Oyster (Ostrea edulis) & 1 & - & 1 & - \\
\hline Common edible cockle (Cerastoderma edule) & - & 3 & - & 2 \\
\hline \multicolumn{5}{|l|}{ Insecta } \\
\hline Pupae & - & - & - & + \\
\hline \multicolumn{5}{|l|}{ Crustacea } \\
\hline Barnacle (Balanus sp.) & - & 5 & - & - \\
\hline Unidentified: crab size & - & 2 & - & 1 \\
\hline Unidentified: lobster size & - & - & - & 1 \\
\hline \multicolumn{5}{|l|}{ Amphibians } \\
\hline Green frog (Rana esculenta) & - & - & - & 1 \\
\hline Common frog (Rana temporaria) & - & - & - & 5 \\
\hline Frog (Rana sp.) & - & - & - & 19 \\
\hline Common toad (Bufo bufo) & - & - & - & 3 \\
\hline Toad (Bufo sp.) & - & - & - & 3 \\
\hline Unidentified anuran remains & - & 9 & - & 61 \\
\hline \multicolumn{5}{|l|}{ Birds } \\
\hline Grey heron (Ardea cinerea) & - & 4 & 20 & 5 \\
\hline Mute swan (Cygnus olor)/Whooper swan (C. cygnus) & - & - & - & 1 \\
\hline Greylag or domestic goose (Anser anser ?f. domestica) & - & 1 & 2 & - \\
\hline Mallard or domestic duck (Anas platyrhynchos ?f. domestica) & - & - & - & 1 \\
\hline Duck (Anatidae sp.) & - & 2 & - & 1 \\
\hline
\end{tabular}


TABLE 7 (Continued)

\begin{tabular}{|c|c|c|c|c|}
\hline & $\begin{array}{c}\text { Chute A } \\
\text { HC }\end{array}$ & $\begin{array}{c}\text { Chute A } \\
5 \mathrm{~mm}\end{array}$ & $\begin{array}{c}\text { Chute B } \\
\text { HC }\end{array}$ & $\begin{array}{c}\text { Chute B } \\
5 \mathrm{~mm}\end{array}$ \\
\hline Grey partridge (Perdix perdix) & - & 15 & 7 & 34 \\
\hline Domestic fowl (Gallus gallus f. domestica) & 2 & 52 & 46 & 44 \\
\hline Woodcock (Scolopax rusticola) & - & 5 & - & 1 \\
\hline Wader (Charadriiformes sp.) & - & 3 & 1 & 3 \\
\hline Domestic pigeon (Columba livia f. domestica) & _- & 1 & - & 1 \\
\hline Pigeon or dove (Columbidae sp.) & - & 6 & - & 7 \\
\hline Barn owl (Tyto alba) & - & 1 & - & - \\
\hline House sparrow (Passer domesticus) & - & 1 & - & 1 \\
\hline Passerine: medium size (Passeriformes sp.) & _- & - & - & 1 \\
\hline Passerine: small size (Passeriformes $\mathrm{sp}$.) & - & 2 & - & - \\
\hline Unidentified & 2 & 228 & 60 & 319 \\
\hline Eggshell fragments & - & + & - & + \\
\hline \multicolumn{5}{|l|}{ Wild mammals } \\
\hline Mole (Talpa europaea) & - & 2 & - & 6 \\
\hline Bat (Chiroptera sp.) & - & 1 & - & - \\
\hline Rabbit (Oryctolagus cuniculus) & - & 68 & 1 & 4 \\
\hline Brown hare (Lepus europaeus) & - & 1 & 1 & 4 \\
\hline Bank vole (Clethrionomys glareolus) & - & 2 & - & - \\
\hline Field vole (Microtus agrestis)/Common vole (M. arvalis) & - & 2 & - & 1 \\
\hline Vole (Microtidae sp.) & - & 1 & - & - \\
\hline Harvest mouse (Micromys minutus) & - & - & - & 1 \\
\hline House mouse (Mus musculus) & - & 2 & - & - \\
\hline Unidentified rodent: house mouse size & - & - & - & 4 \\
\hline Unidentified rodent: black rat size (Rattus rattus) & - & 3 & - & - \\
\hline Unidentified rodent (Rodentia sp.) & - & 1 & - & 19 \\
\hline Beech marten (Martes foina)/Pine marten (Martes martes) & - & - & 2 & 11 \\
\hline \multicolumn{5}{|l|}{ Domesticated mammals } \\
\hline Cat (Felis silvestris f. catus) & - & - & - & 26 \\
\hline Dog (Canis lupus f. familiaris) & _ & _- & - & 30 \\
\hline Pig (Sus scrofa f. domestica) & 1 & 34 & 1 & 9 \\
\hline Cattle (Bos primigenius $\mathrm{f}$. taurus) & 20 & 40 & 42 & 13 \\
\hline Sheep (Ovis ammon f. aries) & 1 & 7 & 5 & 7 \\
\hline Sheep (Ovis ammon f. aries)/Goat (Capra aegagrus $\mathrm{f}$. hircus) & 4 & 36 & 14 & 12 \\
\hline \multicolumn{5}{|l|}{ Unidentified mammal remains (size) } \\
\hline Ribs: large & 6 & 9 & 8 & 13 \\
\hline Ribs: medium & 5 & 117 & 35 & 17 \\
\hline Ribs: small & - & 12 & - & 25 \\
\hline Vertebrae: large & - & - & 5 & 14 \\
\hline Vertebrae: medium & 1 & 34 & 19 & 9 \\
\hline Vertebrae: small & - & 8 & - & 1 \\
\hline Other unidentified & 23 & 1,625 & 133 & 2,676 \\
\hline Total & 66 & 2,677 & 527 & 4,753 \\
\hline
\end{tabular}

$\mathrm{HC}=$ collected by hand $5 \mathrm{~mm}=$ fraction of sieved residue larger than $5 \mathrm{~mm} ;+=$ present, but not counted .

the only wild mammals likely to have been eaten, although the wild status of the rabbit is uncertain. ${ }^{146}$

The variety of bird species in the $>5 \mathrm{~mm}$ sieved fraction is surprisingly high and includes grey heron, goose, ${ }^{147}$ a duck species, partridge, domesticated fowl, woodcock, at least one wader species, domesticated dove, ${ }^{148}$ barn owl, and house sparrow. However, most of the bird bones were too fragmented to be identified. The same is true of 
the eggshell fragments, which were not counted. It can be assumed that all the bird bones - including the heron - come from animals which were eaten, except perhaps the barn owl. ${ }^{149}$ The skeletal elements of domesticated fowl, partridge and woodcock represent adult birds, but the heron bones come from juvenile specimens.

Whereas the amphibians and terrestrial or freshwater molluscs must be intrusive, the marine molluscs, crustaceans and most of the fish were almost certainly consumed. Mussels dominate the marine molluscs, followed by a small number of cockles and one oyster shell. The crustaceans consist of barnacles (probably once attached to the mussels) and two fragments of an unidentified crab species.

The hand-collected finds from chute A contained no fish bones, illustrating how difficult the recovery of these is by traditional excavation techniques. The sieved fractions, however, show a variety of species (Table 8), derived from a range of aquatic biotopes. So far, the $2.5 / 5 \mathrm{~mm}$ fraction from two of the sixteen samples from this chute have been analysed. Find densities were not high and, more importantly, a large part of the material remained unidentified. The percentage of unidentifiable fish remains is significantly higher than that in the comparable fraction of the sieved residues from the other chute. Perhaps the less favourable preservation conditions in chute A led to a higher degree of fish-bone fragmentation. This interpretation is corroborated by the near absence of fish remains in the only sample from the $0.5 / 2.5 \mathrm{~mm}$ fraction examined.

The marine fish consist of ray species, herring, gadids (cod, haddock and whiting), ${ }^{150}$ conger eel, and flatfish. The flatfish are represented by a single find of turbot and by the Soleidae and Pleuronectidae families. Although most of the Pleuronectidae bones could not be identified, a few were recognized as flounder. Four finds of sole could not be ascertained to species. The freshwater fish comprise eel, carp and at least one other cyprinid (a Leuciscus species), pike and perch. The last ecological group amongst the fish remains is represented by a single find of salmon, a species that lives in marine waters but migrates upriver to spawn. On the whole, the fish remains must represent human consumption refuse. Even the fish bones from the lowest levels of the deposits investigated come from specimens of rather large size classes, unlike a natural death assemblage.

\section{CHUTE B: INVENTORY AND TAPHONOMY}

As both the hand-collected animal remains and those from the $>5 \mathrm{~mm}$ sieved fraction in the second chute resemble strikingly the contents of chute A (Table 7), only a few exceptions will be noted. The medium-sized mammal vertebrae and ribs are less frequent in B. The same is true of the rabbit remains. Dog, cat, a marten species and the harvest mouse were not found in chute A. The dog bones belong to at least three different individuals, all of juvenile age. On the basis of tooth eruption, a preserved mandible must come from a newborn puppy. The cat remains could all derive from the same incomplete skeleton and represent a kitten only a few weeks old. The bones from a marten species could also come from the same skeleton, again from a juvenile specimen - perhaps of a beech marten, which live closer to human habitation than the pine marten. ${ }^{151}$

The same bird species occur as in A, with the exception of the barn owl and with the addition of a swan species and the mallard (or perhaps domesticated duck). As the mallard was domesticated late, ${ }^{152}$ it is not usually possible to distinguish between the wild and the domestic form in late medieval or early post-medieval material. All the bird species could have been eaten.

Chute B contained significantly more anuran remains, of which three species - green frog, common frog and common toad - were identified. Terrestrial and freshwater molluscs are dominated by common valve snail, common bithynia and especially pond snails. Most of these aquatic species were found in the chute outflow into the moat. The insect pupae (probably of flies) must also have been intrusive. Both the size classes of crab and lobster are present amongst the crustaceans.

Whereas the fish remains in the $>5 \mathrm{~mm}$ fraction derive from samples from both the chute fill and its outflow into the moat, the $2.5 / 5 \mathrm{~mm}$ fraction consists only of those from the outflow, which was richer in fish bones (Table 8). It is not clear to what extent the greater quantity of fish remains in chute $\mathrm{B}$ than in $\mathrm{A}$ is due to the larger volume of the fill, human depositional factors, or differences in preservation conditions.

Gudgeon, roach and rudd were not identified amongst the cyprinids from chute A. However, the most striking characteristic of the freshwater fish assemblage is the quantity of eel bones in the $2.5 / 5 \mathrm{~mm}$ fraction, mainly from the lowest outflow level. Most are of large specimens, 300 to $700 \mathrm{~mm}$ long, typical of the sizes selected for human consumption, which is also the case with the cyprinid remains. Although salmon is absent from chute B, smelt and three-spined stickleback are new anadromous species. The spectrum of marine fish also includes a number of species not identified from chute A, namely spotted ray, possibly common skate, a sea-robin species and plaice. The most 
TABLE 8

Middelburg castle. Fish remains: number of specimens.

\begin{tabular}{|c|c|c|c|c|c|}
\hline & $\begin{array}{c}\text { Chute A } \\
5 \mathrm{~mm}\end{array}$ & $\begin{array}{c}\text { Chute A } \\
2.5 \mathrm{~mm}\end{array}$ & $\begin{array}{c}\text { Chute B } \\
\text { HC }\end{array}$ & $\begin{array}{c}\text { Chute B } \\
5 \mathrm{~mm}\end{array}$ & $\begin{array}{c}\text { Chute B } \\
2.5 \mathrm{~mm}\end{array}$ \\
\hline \multicolumn{6}{|l|}{ Freshwater fish } \\
\hline Common eel (Anguilla anguilla) & - & 9 & - & 49 & 802 \\
\hline Gudgeon (Gobio gobio) & - & - & - & - & 1 \\
\hline Roach (Rutilus rutilus) & - & - & - & 3 & - \\
\hline Rudd (Scardinius erythrophthalmus) & - & - & - & - & 2 \\
\hline Dace/ ide/chub (Leuciscus sp.) & 2 & - & - & - & - \\
\hline Carp (Cyprinus carpio f. domestica) & 2 & - & - & - & 3 \\
\hline Cyprinid (Cyprinidae sp.) & 56 & $14(10)$ & - & 182 & $156(611)$ \\
\hline Pike (Esox lucius) & 7 & - & - & 23 & 13 \\
\hline Perch (Perca fluviatilis) & 1 & - & - & 18 & 12 \\
\hline Perches (Percidae sp.) & 3 & - & - & 10 & $7(132)$ \\
\hline \multicolumn{6}{|l|}{ Anadromous fish } \\
\hline Salmon (Salmo salar) & 1 & - & - & - & - \\
\hline Smelt (Osmerus eperlanus) & - & - & - & - & 6 \\
\hline Three-spined stickleback (Gasterosteus aculeatus) & - & - & - & - & 34 \\
\hline \multicolumn{6}{|l|}{ Sea fish } \\
\hline Thornback ray (Raja clavata) & 17 & - & - & 16 & 6 \\
\hline Spotted ray (Raja montagui) & - & - & - & - & 1 \\
\hline cf. Common skate (cf. Raja batis) & - & - & - & - & 1 \\
\hline Ray sp. (Raja sp.) & 4 & - & - & 8 & 2 \\
\hline Cartilagenous fish (Chondrichthyes sp.) & - & 1 & - & - & 16 \\
\hline Conger eel (Conger conger) & 21 & - & - & 2 & - \\
\hline Herring (Clupea harengus) & 1 & 22 & - & 3 & 229 \\
\hline Clupeids (Clupeidae sp.) & - & - & - & - & 20 \\
\hline Cod (Gadus morhua) & 2 & - & 1 & 8 & - \\
\hline Whiting (Merlangius merlangus) & - & 3 & - & 2 & 61 \\
\hline Haddock (Melanogrammus aeglefinus) & 47 & - & - & 2 & - \\
\hline Gadids (Gadidae sp.) & 8 & 10 & - & 67 & 78 \\
\hline Turbot (Psetta maxima) & - & 1 & - & - & 1 \\
\hline Plaice (Pleuronectes platessa) & - & - & - & 20 & 3 \\
\hline Flounder (Platichthys flesus) & 3 & - & 1 & 15 & 7 \\
\hline Righteye flounders (Pleuronectidae sp.) & 61 & 6 & 1 & 445 & 274 \\
\hline Sole sp. (Solea sp.) & 3 & 1 & - & 2 & 20 \\
\hline Sea robins (Triglidae sp.) & - & - & - & - & 1 \\
\hline Total identified fish & 239 & 67 & 3 & 875 & 1,756 \\
\hline Unidentified fish & 53 & 173 & - & 229 & 951 \\
\hline Total & 292 & $240(10)$ & 3 & 1,104 & $2,707(743)$ \\
\hline$\%$ identified fish & 82 & 28 & - & 79 & 65 \\
\hline$\%$ unidentified fish & 18 & 72 & - & 21 & 35 \\
\hline
\end{tabular}

$\mathrm{HC}=$ collected by hand $5 \mathrm{~mm}=$ fraction of sieved residue larger than $5 \mathrm{~mm} ; 2.5 \mathrm{~mm}=$ fraction of sieved residue between $2.5-5 \mathrm{~mm}$; in brackets $=$ number of scales .

Chute A yielded no fish remains collected by hand. 
notable differences in comparison with the sea-fish assemblage from chute $\mathrm{A}$ are the near absence of haddock and the high frequency of flatfish bones.

A survey of the fish remains from the $0.5 /$ $2.5 \mathrm{~mm}$ fraction underlines the abundance of eel bones. ${ }^{153}$ Remarkably, fish remains were plentiful in this fraction of the sieved residue, which, together with the fact that most of the fish remains from the $2.5 / 5 \mathrm{~mm}$ fraction were identifiable, points to the better preservation conditions for small bones in chute B.

\section{ANIMAL PRODUCTS AND THE FOOD ECONOMY}

Despite a possible, but slight, discrepancy in dating between the fills of the two structures, the similarities in species spectrum and taphonomy warrant treating the assemblages as one.

Most of the meat supply was obtained by slaughtering domesticated mammals (cattle, pig and sheep). As the material studied was probably consumed by troops garrisoned in the castle in wartime, the question arises whether this livestock was raised in the castle or acquired from nearby farms. Given the frequent changes of occupying troops, it is unlikely that food production could have been maintained in the castle bailey. The hunting of hare and rabbit would only have constituted a minor supplement to the meat diet, although the latter may have been kept.

Domesticated fowl, possibly domesticated geese and domesticated pigeons and their eggs may have been raised in the castle or locally. The other bird species must have been hunted in aquatic biotopes for swans, mallards, juvenile herons, in meadows and fields for partridges and possibly waders, and in woodland for woodcock. The bird pots, ceramic containers to tempt passerines to nest, allowed the capture of young birds. This technique was used in the Low Countries to snare starlings, a species not formally identified amongst the material, although a bone from a medium-sized songbird was present. ${ }^{154}$

Another important food resource was freshwater fish, especially cyprinids and eel, either acquired locally or caught by the soldiers themselves. The bone fragment counts show that freshwater fish formed a third to half of the fish-bone assemblages (Table 9). Late-medieval Flemish non-urban sites tend to have higher frequencies of freshwater fish than urban ones, but these include a high proportion of carp bones. ${ }^{155}$ As carp was usually farmed in ponds belonging to high-status sites such as castles and abbeys, ${ }^{156}$ its virtual absence at Middelburg is significant. Without it, the frequency of freshwater fish is unusually high and
TABLE 9

Middelburg castle. Fish remains: frequencies by ecological groups and of main marine-fish taxa.

\begin{tabular}{|c|c|c|c|c|}
\hline & $\begin{array}{c}\text { Chute } \\
\text { A } \\
5 \mathrm{~mm}\end{array}$ & $\begin{array}{c}\text { Chute } \\
\text { A } \\
2.5 \mathrm{~mm}\end{array}$ & $\begin{array}{c}\text { Chute } \\
\text { B } \\
5 \mathrm{~mm}\end{array}$ & $\begin{array}{c}\text { Chute } \\
\text { B } \\
2.5 \mathrm{~mm}\end{array}$ \\
\hline Ecological groups & $\%$ & $\%$ & $\%$ & $\%$ \\
\hline Freshwater fish & 29.7 & 34.3 & 32.6 & 56.7 \\
\hline Anadromous fish & 0.4 & 0.0 & 0.0 & 2.3 \\
\hline Seafish & 69.9 & 65.7 & 67.4 & 41.1 \\
\hline $\begin{array}{l}\text { Main taxa of } \\
\text { marine fish }\end{array}$ & $\%$ & $\%$ & $\%$ & $\%$ \\
\hline Clupeids & 0.6 & 50.0 & 0.5 & 34.5 \\
\hline Cod & 1.2 & 0.0 & 1.4 & 0.0 \\
\hline Haddock & 28.1 & 0.0 & 0.3 & 0.0 \\
\hline Whiting & 0.0 & 6.8 & 0.3 & 8.5 \\
\hline Gadids & 4.8 & 22.7 & 11.4 & 10.8 \\
\hline Flatfish & 40.1 & 18.2 & 81.7 & 42.3 \\
\hline Others & 25.1 & 2.3 & 4.4 & 3.9 \\
\hline
\end{tabular}

$\mathrm{HC}=$ collected by hand; $5 \mathrm{~mm}=$ fraction of sieved residue larger than $5 \mathrm{~mm} ; 2.5 \mathrm{~mm}=$ fraction of sieved residue between $2.5-5 \mathrm{~mm}$; in brackets $=$ number of scales.

Chute A yielded no fish remains collected by hand.

suggests a reliance on local food sources. The absence of carp may also show that the castle's fish ponds - if it ever had any - were no longer maintained.

Finally, imported marine foodstuffs were significant. The consumption of marine molluscs, especially mussels, must have been important. The crustaceans found amongst the consumption refuse probably contributed little to the diet and were perhaps part of the contents of fish baskets brought to the site. Vital, however, for the survival of the troops stationed at the castle must have been the marine fish, especially clupeids (possibly exclusively herring), ${ }^{157}$ gadids and flatfish (Table 9). ${ }^{158}$ The low numbers of cod, and the high frequencies of flatfish and gadids such as whiting and, in one of the chutes, haddock, point to a coastal origin for the imported fish. Only herring must have been fished in open waters. Most of the marine fish such as herring, gadids and flatfish could have been processed by drying and salting before being delivered to the site. As cured fish could last for a considerable length of time, it was essential provisions for a garrison whose supply routes could be cut in times of war. During the Spanish-Dutch wars the nearby marine fishery of Zeeland was from time to time reduced in scale and, due to piracy at sea, often had to limit itself to fishing close to the coast. ${ }^{159}$ Another explanation for the dominance of coastal species 
amongst the marine fish could lie in the fact that in wartime the castle had no regular access to a market in order to purchase food. In that case, fish was perhaps most often bought directly from local fishermen who engaged in small-scale activity close to land.

It is not known whether troops were provisioned centrally or had to fend for themselves. There is no evidence of over-representation of particular skeletal elements amongst the large mammal bones which would indicate preserved food such as hams. On the other hand, the local freshwater fish and the variety of hunted birds suggest that the garrison secured some of its supplies independently.

It could be argued that plant rather than animal products would have sufficed to feed the soldiers, although such a restricted menu may not have maintained morale. The artefacts do, however, suggest that the waste in the garderobe chutes was derived from elite rather than rank-and-file consumption. Officers would have expected a high proportion of animal proteins and fat in their diet. Although early modern armies would not have eaten the carp or large game found in the castles of feudal lords, ${ }^{160}$ veal can be considered a luxury and perhaps the hunted birds may also have been regarded as a delicacy. ${ }^{161}$ On the other hand, farmers would be prepared to dispose of young bulls without harming reproduction potential, milk production or the need for traction animals. Similarly, the hunted birds were perhaps only an addition to the menu in times of need. The study of data from elsewhere in the castle may clarify these problems of interpretation.

\section{FRUITS AND SEEDS}

\section{By BRIGITTE COOREMANS}

\section{INTRODUCTION AND TAPHONOMY}

In both chutes samples of about 10 litres of sediment were taken at intervals of 50 to $100 \mathrm{~mm}$. Because of the abundance of material, only the samples in the bottom layers below the water table were selected for analysis. Half of the samples were studied in detail, the other half evaluated for their macrobotanical contents.

It soon became clear that the composition of the sediment was almost homogeneous, and that the differences are due to variations in preservation. Because of the similarity in their botanical contents, the deposits must have accumulated in a short period of time. In both cases the bottom layers were rich in macroremains, diminishing towards the top, and disappearing altogether at a certain level. In each case two different deposits were recognized: the fill of the chute and its outflow into the moat (Fig. 5). The bottom layer of the fill was richer than the underlying top layer of its outflow, which could suggest that the deposits were formed in differing ways or in two phases. Perhaps part of the contents of the fill slid into the moat, after which the chutes continued to be filled.

The samples were gently washed through a stack of sieves with meshes of 5, 2.5, 1 and $0.5 \mathrm{~mm}$. Then each fraction was sorted for seeds and fruits. Almost all the macrobotanical material was waterlogged, although a few remains were mineralized or charred. After sorting, the botanical material was identified with the aid of a stereo microscope with a magnification from 5 to 63 times. To facilitate quantitative comparison between different samples all numbers were, wherever possible, calculated per litre of sediment, using a semiquantitative scoring system. ${ }^{162}$

\section{RESULTS}

As the results obtained from the two chutes are similar, they are discussed together.

\section{CEREALS AND OTHER STARCH SUPPLIERS}

Five different cereal taxa were recovered: oats (Avena sp.), bread wheat (Triticum aestivum), rye (Secale cereale), probably barley (cf. Hordeum sp.) and buckwheat (Fagopyrum esculentum). They are common in medieval and post-medieval Flemish sites. ${ }^{163}$

Not surprisingly only a few bran fragments remained in the bottom of chute B. ${ }^{164}$ As cereal bran is delicate, it may have been damaged and pulverized when the samples were dried or may have been removed prior to baking white bread. As bran passes through the human digestive tract and is excreted, its presence in latrine sediment may point to the consumption of bread and/or porridge. Some carbonized grains were present as well. In the absence of the floret bases, ${ }^{165}$ it is not possible to ascertain whether the few oats grains found were wild or cultivated. Although, on the one hand, oats are not considered ideal for human consumption, oatmeal porridge could have figured on the menu. Besides, oats were the main ingredient for brewing beer well into the 16th century. On the other hand, they were also an important component of animal fodder, especially for horses. ${ }^{166}$ Barley too was grown as fodder and in times of hardship was used for baking bread. ${ }^{167}$ It also gained importance as a component for brewing beer. ${ }^{168}$ Rye and bread wheat were the main cereals for human consumption. Valve fragments of, as 
well as pollen from, buckwheat consistently appear in the samples. Buckwheat is frequently found in archaeobotanical contexts. ${ }^{169}$ It was an ingredient of pancakes and porridge, but buckwheat flour is not suitable for baking bread. It was also used as cattle fodder and its seeds as chicken feed. ${ }^{170}$

These crops may have been grown locally and supplied to the garrison. ${ }^{171}$ It is not surprising that there is little evidence of their presence. The soft grains perish easily unless carbonized or mineralized. Most would have been ground into flour. Sometimes cornfield weeds like corncockle (Agrostemma githago) and cornflower (Centaurea cyanus) are the only indication of cereal consumption.

\section{PULSES, VEGETABLES AND KITCHEN HERBS AND SPICES}

Although pulses have always played an important part in human nutrition, they are rarely found in great numbers in archaeobotanical contexts due to the way they are harvested, processed and prepared. Only pea (Pisum sativum) and lentil (Lens culinaris) could be identified.

Evidence of vegetables is also scarce. They are grown for the consumption of leaves, roots and tubers, which have little chance of being preserved, and the crops are generally harvested before seed production. We cannot tell whether the few carrot seeds (Daucus carota) were grown for eating or belonged to the local grassland vegetation. However, wild carrot roots are unsuitable for human consumption. Red carrots, and the yellow ones from which our current orange-coloured carrot originated, were grown in vegetable gardens. ${ }^{172}$ It is difficult to differentiate on the basis of the seed morphology the various cultivated and wild species of cabbages (Brassica sp.). The surface of some seed fragments shows a reticulate pattern with elongated meshes characteristic of $B$. oleracea. ${ }^{173}$ According to the written sources, ${ }^{174} \mathrm{a}$ wide variety of cabbages formed part of the regular diet. Before the introduction of potatoes in the 17 th century cabbages were, together with turnips, carrots and beans or peas, boiled into a hotchpotch or some kind of thick soup called potagie (pottage), which formed the main daily dish in the countryside. ${ }^{175}$ The Cucumis seed's truncated base with a central radicle opening points to cucumber $(C$. sativus) rather than to melon (C. melo) (Fig. 19:1). ${ }^{176}$ Botanically cucumber and gherkin belong to the same species and therefore cannot be distinguished on the basis of their seeds. Old illustrations of these fruit (Fig. 20) show more resemblance to gherkins than to the cucumbers we know today. ${ }^{177}$ Finds of cucumber seeds are rare. ${ }^{178}$ So far in Flanders they have only been found in Roman Tongeren ${ }^{179}$ and medieval and postmedieval Bruges and Mechelen. ${ }^{180}$ Although purslane (Portulaca oleracea) is no longer a well known vegetable in Flanders, the considerable amount of seeds found at Middelburg shows that it must have been greatly appreciated there in the 16 th century.

Kitchen herbs and spices are represented by celery (Apium graveolens), fennel (Foeniculum vulgare), coriander (Coriandrum sativum), summer savory (Satureja hortensis) and grains of paradise (Aframomum melegueta). Except for the last, all can be grown in gardens in our temperate climate; or they were acquired by trade. The first three are regularly found at contemporary sites, while the other two are less common. Celery can grow naturally on brackish soils, but it was also cultivated for consumption. The leaves were used as a vegetable or for seasoning. Varieties with thickened roots such as we eat today, for example, celeriac, did not exist then.

Less common are summer savory (Satureja hortensis) and grains of paradise (Aframomum melegueta). Grain of paradise or Melegueta pepper (Fig. 19:2) is a tropical import from the west African coast. The Portuguese brought this spice to Europe in the late Middle Ages, in particular to the markets of Antwerp and Bruges. ${ }^{181}$ It was a common substitute for black pepper, and mainly used by the well-off. Later, when black pepper had replaced it as a kitchen spice, it was sometimes mentioned as beer flavouring. ${ }^{182}$

\section{FRUITS AND NUTS}

As usual, fruit species are better represented both in absolute numbers and in the quantity of different species. Generally speaking, the sturdier fruit stones have a better chance of survival. Some species may have been gathered in the wild and others would have been grown in gardens and orchards, whereas those of exotic origin must have been acquired through trade.

Elder (Sambucus nigra) and blackberry (Rubus fruticosus) are typical examples of species gathered locally and appear consistently in archaeological contexts. Elder is inextricably linked to human occupation and is an indicator of places rich in nitrates. It has been used in various ways for making jam, juice, wine and gin and as a medicine. Blackberry is a very common species found at the edges of woods, in hedges, on waste ground, etc. Although the less common raspberry (Rubus idaeus) grows wild, it was often planted in gardens. The presence of sloes (Prunus spinosa) in the archaeobotanical record may at first sight be 

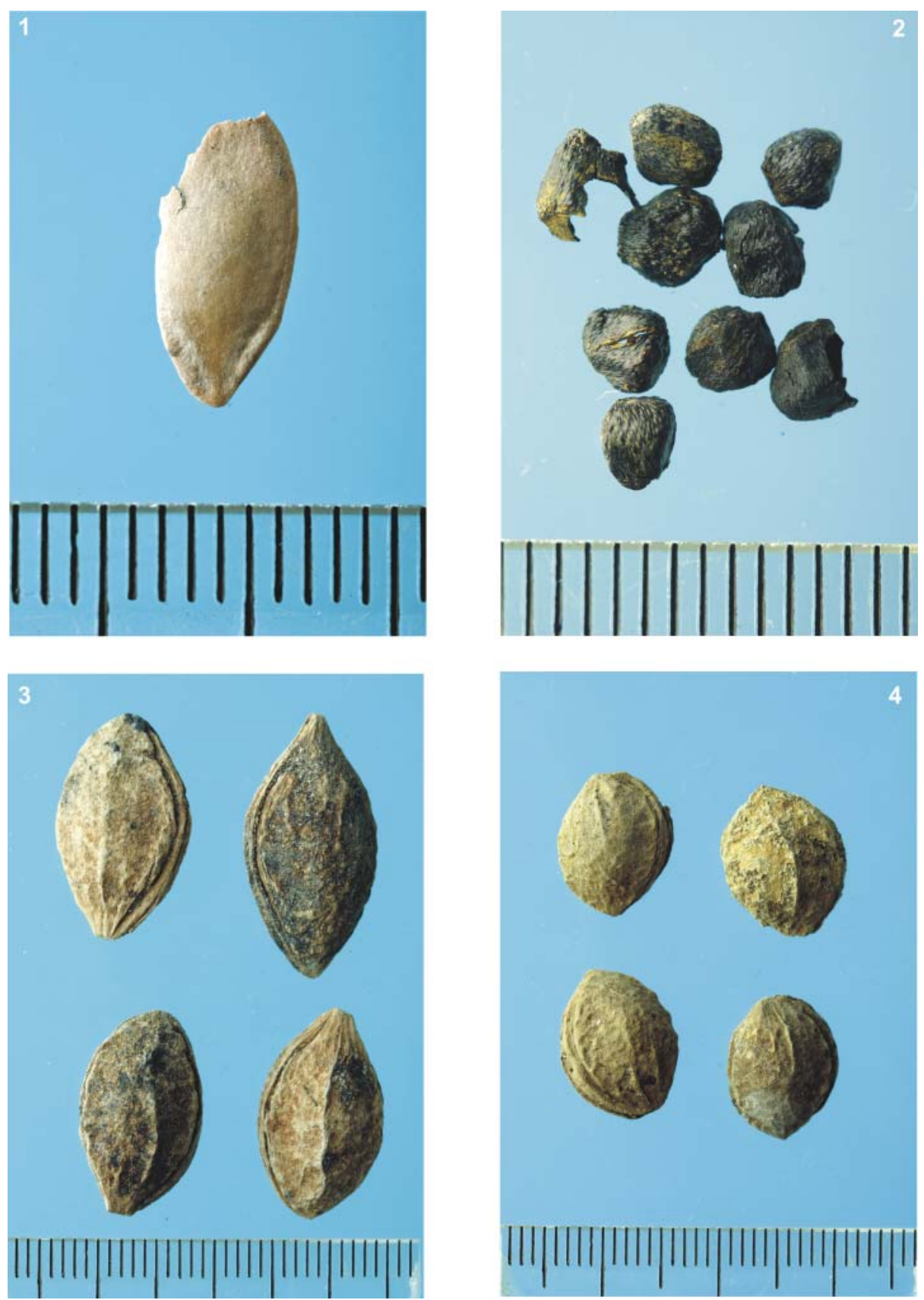

FIG. 19

Middelburg castle. Seeds: 1. cucumber (Cucumis cf. sativus); 2. grains of paradise (Aframomum melegueta); 3. true plumstones (Prunus domestica ssp. domestica); 4. plumstones of damson type (Prunus domestica cf. ssp. insititia) (scale divisions in $\mathrm{mm}$ ). 


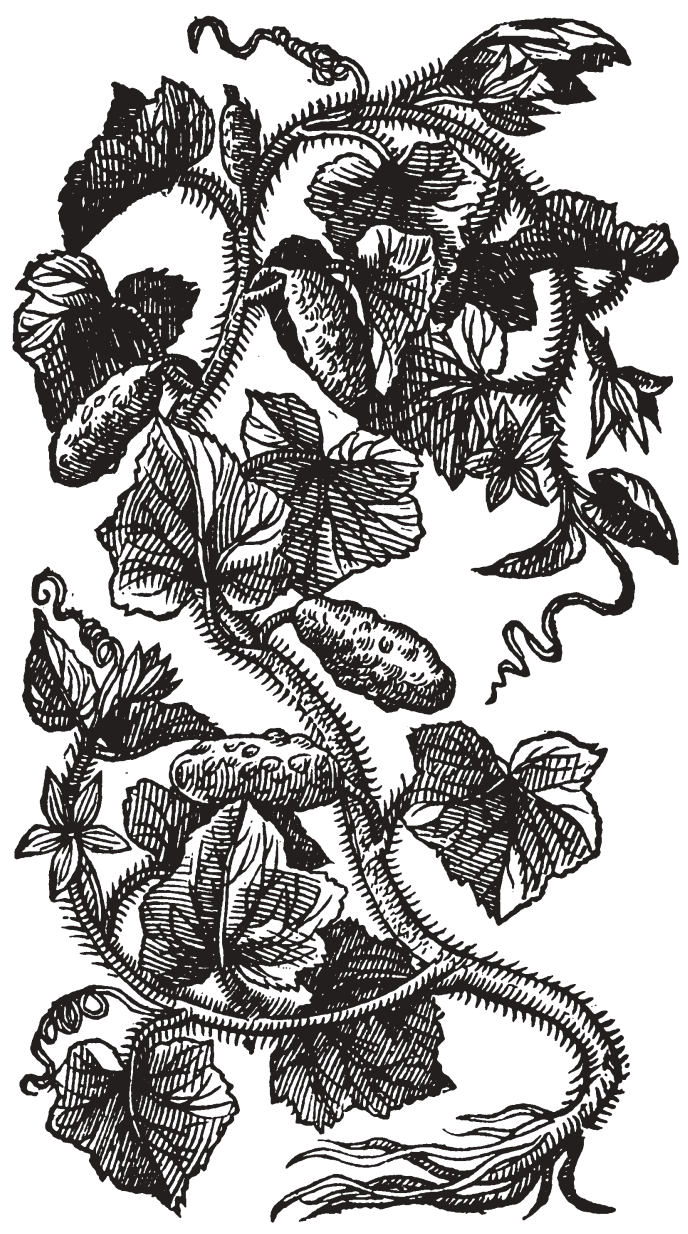

FIG. 20

Middelburg castle. Drawing of 'cucumber' by Dodoens (1644, 1034).

somewhat surprising as the dark blue fruit of this shrub is said to be too sour to eat. They may have been used to make wine; apparently sloe becomes less acid when dried or baked. ${ }^{183}$

Strawberry (Fragaria vesca) and currant or gooseberry (Ribes sp.) may have been collected from the wild, grown in gardens or bought. ${ }^{184}$ Bilberries (Vaccinium sp.) were not cultivated, but were often picked for sale at the market. ${ }^{185}$ Due to the condition of the Ribes sp. remains, no distinction was made between black currant ( $R$. nigrum), red currant ( $R$. rubrum) or gooseberry ( $R$. uvacrispa). Red currant and gooseberry were available in the market, while black currant was not grown or eaten because of its bad taste. ${ }^{186}$ Strawberry pips (Fragaria vesca) were found in vast quantities. Wild strawberry is still fairly common in Flanders, but was cultivated since the late Middle Ages, especially in the vicinity of Brussels. ${ }^{187}$

Walnut (Juglans regia) and hazel (Corylus avellana) nutshell fragments are commonly found. Hazel is indigenous, while walnut is one of the many Roman introductions. Wild hazel nuts may have been gathered, but hazel was also planted in gardens and is thought to have been cultivated, in particular in Flanders. ${ }^{188}$ Walnut used to be common in gardens and is also known to have been planted on city walls, but the possibility that the nuts were purchased cannot be ruled out.

Apple (Malus domestica), pear (Pyrus communis), sweet and sour cherries (Prunus avium and cerasus) and plums and damson-type plums (Prunus domestica ssp. domestica and cf. ssp. insititia) figure among commonly cultivated fruit species. Pips, apple core fragments and pear stone cells are typical constituents of human excrement as, unlike larger fruit stones, they are easily swallowed and passed through the digestive system. It seems that sour cherry $(55 \%, 65 \%)$ was more important than sweet cherry $(35 \%, 45 \%)$, as was often recorded at this time. ${ }^{189}$ Plum stones have been divided into two categories, true plums (30\%) (Prunus domestica ssp. domestica) (Fig. 19:3) and the damson-type $(70 \%)(P$. domestica $\mathrm{cf}$. ssp. insititia) (Fig. 19:4). As variations in size, shape and surface patterns of the stones were observed in both groups, several kinds of plum were consumed.

Cornelian cherry (Cornus mas), medlar (Mespilus germanica), black mulberry (Morus nigra) and peach (Prunus persica) figure among the less commonly found fruit species. Cornelian cherry and medlar were frequently grown in orchards. Medlar fruit are usually left after picking to ripen, which renders them soft and palatable. As black mulberry and peach were luxury items, they were not planted in orchards but grown in gardens for personal consumption. ${ }^{190}$ Although peaches may have been imported, the soft fruit is easily damaged in transport. With special attention, they could have been grown in orchards together with medlar and cornelian cherry.

Fig (Ficus carica) and grape (Vitis vinifera) are usually regarded as imports from the Mediterranean. Ancient sources also mention the cultivation of grapes for winemaking and verjuice and for consumption as fruit. ${ }^{191}$ The possibility that the pips derive from locally grown grapes cannot be excluded, but it is less likely to be the case for the figs.

\section{OIL AND FIBRE PLANTS}

The fragmentary black mustard (Brassica nigra) and possibly turnip (B. cf. rapa) remains were 
difficult to identify at species level. Most showed a polygonal mesh pattern characteristic of black mustard. ${ }^{192}$ Where this pattern was less conspicuous, the specimen may belong to turnip or badly preserved $B$. nigra. As they were found fragmented, the seeds may have been pressed to extract oil to make mustard. Some of the Brassica rapa fragments may derive from one of two subspecies, B. rapa ssp. campestris and ssp. rapa. The first is usually grown for its oil-bearing seeds, the second as a vegetable. To judge from the written sources, ${ }^{193}$ the Middelburg fragments are more likely to derive from the vegetable. Turnips were also grown as fodder and may also have been used in the daily pottage. Some were left in the field to flower, after which the seeds were harvested and their oil was used in food preparation or for making mustard. Opium poppy (Papaver somniferum) may also have been a source of oil. As most of the poppy seeds were found intact (in contrast to the remains of Brassica), they were probably consumed whole, sprinkled on bread or cakes.

Linseed (Linum usitatissimum) and hemp (Cannabis sativa) were also cultivated as fibre plants. Linseed or flax is mainly represented by capsule fragments indicating its cultivation in the vicinity. The relatively low number of seeds suggests that the flax was probably grown for its fibres. Written sources confirm this assumption, although they also record its use as animal fodder and the application of its oil in paint and soap manufacture and for lighting. The fibres were used to weave fine linen for clothing as well as for making coarser textiles such as sacks. ${ }^{194}$ Hemp can be used for many of the same purposes as flax, but was also renowned for its medicinal qualities. Its fibres were employed for making rope.

\section{WILD PLANT TAXA}

The wild plant taxa have been classified according to their present ecological categories. ${ }^{195}$ As usual the arable weeds (Table 10) form by far the biggest group and seem to derive from species with varying habitat requirements. Today most of these weeds are found in the class of field and garden weeds. ${ }^{196}$ Some like black bindweed (Fallopia convolvulus), chickweed (Stellaria media), hairy and smooth tare (Vicia hirsuta and $V$. tetrasperma) and narrow-fruited corn salad (Valerianella dentata) show a preference for soils rich in lime and high in nutrients. Others like corncockle (Agrostemma githago), cornflower (Centaurea cyanus), long prickly-headed poppy (Papaver argemone), wild radish (Raphanus raphanistrum) and sheep's sorrel (Rumex acetosella) favour less fertile, more acidic and sandy soils. Some such as corncockle
(Agrostemma githago), black bindweed (Polygonum convolvulus), wild radish (Raphanus raphanistrum) and hairy and smooth tares (Vicia hirsuta and tetrasperma) are thought to have accompanied cereals sown in autumn. Others like scarlet pimpernel (Anagallis arvensis), fat hen (Chenopodium album) and chickweed (Stellaria media) may also have formed part of the weed flora of summer crops and gardens. Fragments of cornflower (Centaurea cyanus) and corncockle (Agrostemma githago) are typical cesspit ingredients. As their seeds are more or less the same size as those of cereal grains, they are difficult to separate by sieving and winnowing. As a result they end up in the grain and are processed with it. The persistent appearance of poisonous corncockle seeds in archaeobotanical contexts is somewhat surprising.

Ruderals are plants with a preference for disturbed habitats rich in nitrate, frequently found in areas around human occupation, where organic matter accumulates. Various field and garden weed taxa like fat hen (Chenopodium album) and chickweed (Stellaria media) are also often found in these ruderal habitats. On the other hand, plants like shepherd's purse (Capsella bursa-pastoris) and knotgrass (Polygonum aviculare) may also have grown in fields lying fallow. Together with greater plantain (Plantago major) they are examples of tread-resistant plants, common on paths and tracks in and around settlements.

Remains of plants representing the vegetation of the local landscape are scarce. Despite Middelburg's proximity to the sea, halophytic species characteristic of a brackish environment were not detected. However, some of the ditch-bank species, such as gipsywort (Lycopus euroapeus), hemp agrimony (Eupatorium cannabinum), common spike-rush (Eleocharis palustris) and great sedge (Cladium mariscus), are to a certain extent salt resistant. ${ }^{197}$ Most of these taxa prefer nutrientrich conditions, indicating that the moat water was dirty. The presence of Pediastrum ${ }^{198}$ and eggs of water flea (Daphnia sp.) confirm this.

\section{CONCLUSION}

There are hardly any direct indications of cereal consumption, although they must have been important in the diet. Arable weeds provide indirect evidence that they were eaten. The diversity of these weeds indicates that cereals were not only supplied by local farmers, but that some must also have been acquired in some other way. It was impossible to determine which cereal was used as food and which as fodder or which one was the most important species. Some of the vegetables, kitchen herbs and spices may have been grown locally in gardens, 
TABLE 10

Middelburg castle. Seeds and fruits.

\begin{tabular}{lccccccc}
\hline Chute & A & A & A & B & B & B & present in \\
Spit & 35 & 31 & 29 & $46 \mathrm{~h}$ & $46 \mathrm{~d}$ & $33 \mathrm{f}$ &
\end{tabular}

\section{USEFUL PLANTS}

\section{Cereals}

Avena sp. (c)

Cerealia fr. (c)

Cerealia epidermis fr.

Fagopyrum esculentum

Hordeum vulgare

Secale cereale

Triticum aestivum (c)

Pulses, vegetables, kitchen herbs and spices

Aframomum melegueta

Aframomum melegueta $\mathrm{fr}$.

Apium graveolens

Brassica $\mathrm{cf}$. oleracea $\mathrm{fr}$.

Coriandrum sativum

Cucumis cf. sativus

Daucus carota

Foeniculum vulgare

Lens culinaris

Pisum sativum (c)

Portulaca oleracea

Satureja hortensis

Fruit and nuts

Cornus mas

Corylus avellana fr.

Corylus avellana fr. (c)

Ficus carica

Fragaria vesca

Juglans regia $\mathrm{fr}$.

Malus domestica

Malus endocarp

Mespilus germanica

Morus nigra

Prunus avium/cerasus

Prunus avium

Prunus cerasus

Prunus domestica

ssp. domestica

cf. ssp. insititia

Prunus sp.

Prunus persica

Prunus spinosa

Pyrus communis

Pyrus stone cells

Pyrus/Malus

Ribes sp.

Ribes flower base

Rubus fruticosus

Rubus idaeus

Rubus sp.

Sambucus nigra

Vaccinium sp.

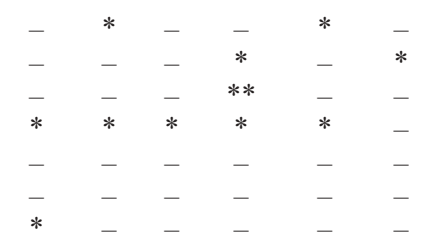

$\begin{array}{cl}- & \text { oats } \\ - & \text { cereals } \\ - & \text { cereal bran fragmens } \\ - & \text { buckwheat } \\ \text { A23 } & \text { barley } \\ \text { B33d } & \text { rye } \\ - & \text { bread wheat }\end{array}$

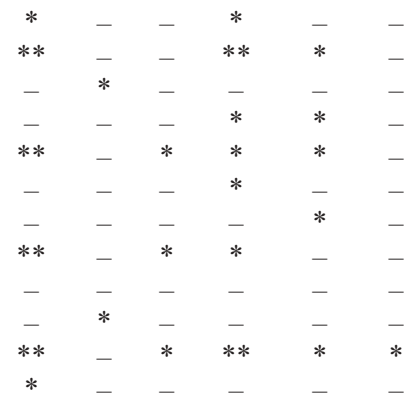

\begin{tabular}{ll}
- & grains of paradise \\
- & (wild) celery \\
- & probably cabbage \\
- & coriander \\
- & probably cucumber \\
- & (wild) carrot \\
- & fennel \\
- & lentil \\
B33c & pea \\
- & purslane \\
- & summer savory \\
- & \\
& \\
- & cornelian cherry \\
- & hazel \\
- & \\
- & fig \\
- & strawberry \\
- & walnut \\
- & apple \\
- & \\
- & medlar \\
- & black mulberry \\
- & sweet or sour cherry \\
- & sweet cherry \\
- & sour cherry \\
- & plum \\
- & true plum \\
- & damson-type \\
- & plums s.l \\
- & peach \\
- & sloe \\
- & pear \\
- & pear or apple \\
- & currant or gooseberry \\
- & \\
- & blackberry \\
- & raspberry \\
- & blackberries \\
\hline
\end{tabular}


TABLE 10 (Continued)

\begin{tabular}{|c|c|c|c|c|c|c|c|c|}
\hline $\begin{array}{l}\text { Chute } \\
\text { Spit }\end{array}$ & $\begin{array}{c}\mathbf{A} \\
35\end{array}$ & $\begin{array}{c}\mathbf{A} \\
31\end{array}$ & $\begin{array}{c}\mathbf{A} \\
29\end{array}$ & $\begin{array}{c}\text { B } \\
46 \mathrm{~h}\end{array}$ & $\underset{46 \mathrm{~d}}{\mathbf{B}}$ & $\begin{array}{c}\text { B } \\
33 \mathrm{f}\end{array}$ & present in & \\
\hline Vitis vinifera & $* *$ & $*$ & $* *$ & $* *$ & $*$ & $*$ & - & grape \\
\hline fruit epidermis & $* * *$ & - & $*$ & $*$ & $*$ & - & - & \\
\hline \multicolumn{9}{|l|}{ Oil and fibre plants } \\
\hline Brassica nigra fr. & - & - & - & $* *$ & $*$ & - & - & black mustard \\
\hline Brassica cf. rapa & - & - & $*$ & - & - & - & - & probably turnip \\
\hline Brassica fr. & - & - & $*$ & $*$ & - & - & - & cabbages \\
\hline Cannabis sativa & $*$ & - & $*$ & $*$ & - & - & - & hemp \\
\hline Linum usitatissimum & $*$ & - & - & $*$ & - & - & - & cultivated flax \\
\hline Linum usitatissimum capsule fr. & $*$ & - & - & $*$ & $* *$ & - & - & \\
\hline Papaver somniferum & $* *$ & - & - & * & - & - & - & opium poppy \\
\hline
\end{tabular}

WILD PLANT TAXA

\section{Plants of fields and gardens}

Agrostemma githago

Agrostemma githago (c)

Agrostemma githago fr.

Anagallis arvensis

Anagallis arvensis $\mathrm{fr}$.

Anthemis arvensis

Centaurea cyanus fr.

Chenopodium album

Fumaria officinalis

Lithospermum arvense

Papaver argemone

Papaver rhoeas/dubium

Fallopia convolvulus

Polygonum lapathifolium

Polygonum lapathifolium (c)

Polygonum persicaria

Ranunculus arvensis

Raphanus raphanistrum fr.

Rumex acetosella

Solanum nigrum

Sonchus asper

Sonchus oleraceus/arvensis

Spergula arvensis

Spergula arvensis fr.

Stellaria media

Urtica urens

Valerianella dentata

Vicia hirsutaltetrasperma (c)

Vicia sativa subsp. angustifolia (c)

Vicia sp. (c)

Ruderals

Capsella bursa-pastoris

Chelidonium majus

Conium maculatum

Lapsana communis

Malva sp.

Plantago major

\begin{tabular}{ccccccll}
- & - & - & $* * *$ & - & - & - & corncockle \\
- & - & - & $*$ & - & - & - & \\
$* * *$ & - & $* *$ & $* * *$ & - & - & - & \\
$*$ & - & - & $*$ & $*$ & - & - & scarlet pimpernel \\
- & - & - & $*$ & - & - & - & \\
- & - & - & $*$ & - & - & - & corn chamomile \\
$* *$ & $*$ & $*$ & $* *$ & $*$ & - & - & cornflower \\
$*$ & $*$ & $*$ & $* *$ & $*$ & - & - & fat hen \\
$*$ & - & - & - & - & - & - & common fumitory \\
$*$ & - & - & - & - & - & - & corn gromwell \\
$*$ & - & - & $*$ & - & - & - & long prickly-headed \\
& & & & & & & poppy \\
- & - & - & $*$ & $*$ & - & - & field or long-headed \\
$*$ & & & & & & & poppy \\
$*$ & $*$ & $*$ & $* * *$ & $*$ & - & - & black bindweed \\
- & - & - & - & $*$ & - & - & pale persicaria \\
$*$ & - & - & - & - & - & - & red shank \\
$*$ & - & - & $*$ & - & - & - & corn crowfoot \\
$* *$ & $*$ & $*$ & $* *$ & $*$ & - & - & wild radish \\
$* *$ & $*$ & - & $* * *$ & $* *$ & - & - & sheep's sorrel \\
$*$ & - & $*$ & - & $*$ & - & - & black nightshade \\
$*$ & - & $*$ & - & $*$ & - & - & prickly sow-thistle \\
$*$ & - & - & $*$ & $*$ & - & - & sow or corn \\
& & & & & & & sow-thistle \\
- & - & - & $*$ & - & - & - & corn spurrey \\
- & - & - & $* *$ & - & - & - & \\
$*$ & - & $*$ & $* *$ & $*$ & - & - & chickweed \\
$*$ & - & - & - & - & - & - & annual nettle \\
- & - & - & $* *$ & $*$ & - & - & narrow-fruited \\
& & & & & & & cornsalad \\
- & - & - & - & $*$ & - & - & hairy or smooth tare \\
- & $*$ & - & - & $*$ & - & - & common vetch \\
- & $*$ & - & - & - & - & - & vetches etc. \\
$*$ & & & & & & & \\
- & $*$ & - & - & - & - & - & shepherd's purse \\
- & - & - & - & $*$ & - & - & greater celandine \\
$*$ & - & - & - & - & - & - & nemlock \\
$*$ & - & - & - & - & - & - & mallowort \\
- & - & - & - & $*$ & - & - & greater plantain \\
\hline & & & & & & &
\end{tabular}


TABLE 10 (Continued)

\begin{tabular}{|c|c|c|c|c|c|c|c|c|}
\hline $\begin{array}{l}\text { Chute } \\
\text { Spit }\end{array}$ & $\begin{array}{c}\mathbf{A} \\
35\end{array}$ & $\begin{array}{l}\mathbf{A} \\
31\end{array}$ & $\begin{array}{c}\text { A } \\
29\end{array}$ & $\begin{array}{c}\text { B } \\
46 h\end{array}$ & $\begin{array}{c}\text { B } \\
46 \mathrm{~d}\end{array}$ & $\begin{array}{c}\text { B } \\
33 \mathrm{f}\end{array}$ & present in & \\
\hline Polygonum aviculare & $*$ & - & - & $*$ & $*$ & - & - & knotgrass \\
\hline Polygonum aviculare (c) & - & - & - & - & $*$ & - & - & \\
\hline Ranunculus cf. sardous & - & - & - & * & - & - & - & probably hairy buttercup \\
\hline Urtica dioica & $*$ & - & $*$ & $*$ & $* *$ & - & - & stinging nettle \\
\hline \multicolumn{9}{|l|}{ Plants of grass- and heathland } \\
\hline Anthemis cotula & - & - & - & $*$ & - & - & - & stinking mayweed \\
\hline Betula sp. & $*$ & - & - & $*$ & - & - & - & birch \\
\hline Erica tetralix & $*$ & - & $*$ & * & - & - & - & cross-leaved heath \\
\hline Poa sp. & $*$ & - & $*$ & * & - & - & - & meadow grasses \\
\hline Potentilla erecta & - & - & - & $*$ & - & - & - & tormentil \\
\hline Prunella vulgaris & $*$ & - & - & * & $*$ & - & - & selfheal \\
\hline Ranunculus acris/repens/bulbosus & $*$ & - & - & - & $*$ & - & - & buttercups \\
\hline Ranunculus acris/repens/bulbosus (c) & - & - & - & - & $*$ & - & - & \\
\hline Stellaria graminea & $*$ & - & - & * & - & - & - & lesser stitchwort \\
\hline \multicolumn{9}{|l|}{ Wetland plants } \\
\hline Cladium mariscus & - & $*$ & - & - & - & - & - & great sedge \\
\hline Eleocharis palustris & $*$ & - & - & - & - & - & - & common spike-rush \\
\hline Eupatorium cannabinum & - & - & - & - & $*$ & - & - & hemp agrimony \\
\hline Lycopus europaeus & - & - & - & $*$ & - & - & - & gipsywort \\
\hline Ranunculus flammula & $*$ & - & - & * & - & - & - & lesser spearwort \\
\hline Ranunculus subg. Batrachium & - & - & - & $*$ & - & - & - & water crowfoots \\
\hline Scirpus setaceus & - & - & - & $*$ & - & - & - & bristle club-rush \\
\hline Scirpus lacustris & - & - & - & - & $*$ & - & - & common club-rush \\
\hline Stellaria alsine & - & - & - & $*$ & - & - & - & bog stitchwort \\
\hline \multicolumn{9}{|l|}{ Other } \\
\hline Apiaceae & - & - & $*$ & $*$ & $*$ & - & - & carrot family \\
\hline Apiaceae (min) & - & - & $*$ & - & - & $*$ & - & \\
\hline Asteraceae & $*$ & - & - & - & - & - & - & daisy family \\
\hline Atriplex sp. & $*$ & - & - & $*$ & $*$ & - & - & oraches \\
\hline Brassicaceae & - & - & - & $* *$ & $*$ & - & - & cabbage family \\
\hline Carex cf. caryophyllacea & - & - & - & $*$ & - & - & - & probably spring-sedge \\
\hline Carex riparia & - & - & - & - & $*$ & - & - & greater pond-sedge \\
\hline Carex sp. & $*$ & - & $*$ & $*$ & $*$ & - & - & sedges \\
\hline Chenopodium sp. & - & - & - & $*$ & - & - & - & goosefoots \\
\hline Chenopodium sp. (min) & - & $*$ & - & - & - & - & - & \\
\hline Chrysanthemum cf. segetum & $*$ & - & - & - & - & - & - & probably corn marigold \\
\hline Cirsium/Carduus fr. & - & - & $*$ & $*$ & - & - & - & thistles \\
\hline Lamium sp. & - & - & - & * & - & - & - & dead-nettles etc. \\
\hline Lamiaceae & - & - & - & $*$ & - & - & - & mint family \\
\hline Mentha arvensis/aquatica & - & - & $*$ & - & - & - & - & corn or water mint \\
\hline $\begin{array}{l}\text { Fallopia convolvulus/Polygonum } \\
\text { aviculare fr. }\end{array}$ & $* *$ & - & $*$ & $* *$ & - & - & - & $\begin{array}{l}\text { black bindweed or } \\
\text { knotgrass }\end{array}$ \\
\hline Rorippa sp. & $*$ & - & - & - & - & - & - & yellow-cresses \\
\hline Rumex sp. & $*$ & $*$ & $*$ & $* *$ & $*$ & - & - & docks \\
\hline Silene sp. & - & - & - & $*$ & $*$ & - & - & campions etc. \\
\hline Silene sp. fr. & $*$ & - & - & $*$ & - & - & - & \\
\hline Viola sp. & $*$ & - & $*$ & $*$ & $*$ & - & - & violets, pansies, etc. \\
\hline Daphnia sp. & $\mathrm{p}$ & $\mathrm{p}$ & $\mathrm{p}$ & $\mathrm{p}$ & $\mathrm{p}$ & $\mathrm{p}$ & & \\
\hline
\end{tabular}

Waterlogged, unless otherwise qualified: $(\mathrm{c})=$ charred; $(\mathrm{min})=$ mineralized.

$*=$ a few specimens present; ${ }^{*}=$ tens; ${ }^{* *}=$ hundreds; ${ }^{* * * *}=$ thousands; $\mathrm{p}=$ present.

s.l. = sensu latu .

$\%=$ proportions of sweet and sour cherries and of true and domestic plums. 
but some must have been obtained through trade. Apparently a lot of fruits and nuts were consumed, including species that could have been collected in the wild, as well as fruits typically cultivated in gardens or grown in orchards. It is not possible to say whether these gardens and orchards were situated in the castle grounds or belonged to people in the neighbourhood. It seems that local farmers provided much of the food, fodder and other useful plants needed at the castle, but a substantial part would as well have been obtained through trade.

Although some of the material recovered would have been discarded as rubbish, at least part of it would have been deposited in human excrement. Fragments of the bigger fruit stones and nut shells, intact small-sized pips, apple core fragments, pear stone cells and fragments of corncockle and cornflower seeds are all botanical characteristics of cesspit fills. ${ }^{199}$ Only bran is missing, probably lost when the samples were dried.

The seed and fruit assemblage is similar to those from other contemporary castle or urban cesspits. ${ }^{200}$ However, the diversity and presence of some exotic and luxurious species like figs, grapes, peach, black mulberry and grains of paradise point to a rather wealthy menu, despite wartime. There is little macrobotanical information about the local environment. There is no clear-cut evidence for the influence of the sea on the local vegetation. The presence of plants which thrive in nutrientrich, wet environments, and of the water flea and Pediastrum indicate that the water in the moat was dirty and slow flowing.

\section{POLLEN ANALYSIS}

\section{By KOEN DEFORCE}

\section{INTRODUCTION: MATERIAL AND METHODS}

Samples for palynological research were available only from chute B. Three different samples were analysed from the lowermost part, the outflow in the moat (Fig. 4). They were processed according to standard techniques, including density separation, acetolysis and treatment with hydrofluoric acid. ${ }^{201}$

\section{RESULTS AND INTERPRETATION}

The pollen content of latrines, cesspits and sewers is difficult to interpret as there are many possible sources from which it can originate. The main ones are faecal material, food, refuse from the kitchen and the rest of the household, and atmospheric pollen rain. ${ }^{202}$ The pollen spectra of the investigated samples from the outflow of the chute clearly consist of two main components, sewage and aquatic (Table 11).

The sewage component is attested by the relative high percentages of pollen from food plants, especially cereals (Cerealia), and of intestinal parasite ova (Fig. 21:1). Cereals are the most abundant pollen type within the group of cultivated plants. This must be the consequence of the consumption of bread, porridge or other kinds of cereal foods. Other sources of Cerealia pollen like straw which might have been thrown down the chute cannot, however, be excluded. Except for rye (Secale cereale), no distinction was made between the different species of cereals. Other cultivated plants identified are chervil (Anthriscus cerefolium), borage (Borago officinalis), buckwheat (Fagopyrum), parsnip (Pastinaca sativa), grape (Vitis vinifera) and hemp type (Cannabis type).

Chervil is not native to Flanders; it was introduced in Roman times. ${ }^{203}$ Until recently, records of chervil from medieval and post-medieval chutes were rare, because these contexts had only been analysed for macrobotanical remains. Now that latrines are more often analysed for pollen as well, the number of records for chervil is growing fast indicating that it may have been a rather popular kitchen herb. ${ }^{204}$ Buckwheat, which is also a common find in medieval and post-medieval chutes, ${ }^{205}$ is attested here by its pollen as well as macro-botanical remains.

Borage, native in the western Mediterranean region, was introduced to the Low Countries in the Middle Ages. ${ }^{206}$ It was cultivated as a kitchen herb and vegetable in gardens. ${ }^{207}$ Nowadays it is hardly known as a food plant, but it is still grown as an ornamental plant. Borage pollen has also been found in medieval cesspits in 's Hertogenbosch in the Netherlands ${ }^{208}$ and in Worcester in England. ${ }^{209}$ Buckwheat and borage are not only food plants but important honey plants as well; buckwheat has even been cultivated for this purpose. The presence of their pollen in the chute might therefore be the consequence of the consumption of honey rather than of the plants themselves. As sugar was an expensive imported product until the 18th century, ${ }^{210}$ before then honey was widely used as a sweetener. However, the presence of valve fragments in the chute suggests that buckwheat was eaten. No botanical macroremains of borage have been found. Since only the flowers and leaves are used, the chances of finding its seeds are low.

The grape pollen probably originates from the consumption of grapes, raisins or most likely wine.

Cannabis type pollen was identified in all the investigated samples. It comprises hemp (Cannabis sativa) and hop (Humulus lupulus). 
TABLE 11

Middelburg castle, chute B. Pollen analysis.

Chute B

Depth below surface $(\mathrm{cm})$

$$
\text { 187-200 }
$$

200-210

220-230

$\begin{array}{lllll}\text { No. } & \% & & \text { No. } & \%\end{array}$

\section{TREES AND SHRUBS}

\section{Alnus}

Betula

Carpinus betulus

Corylus avellana

Fagus sylvatica

Frangula alnus

Fraxinus excelsior

Hedera helix

Malus type

Pinus

Quercus

Salix

Sambucus nigra type

Taxus baccata

Tilia

Ulmus

AP

\section{HERBS}

\section{Cultivated plants}

Anthriscus cerefolium

Borago officinalis

Cerealia (undiff.)

Fagopyrum

Pastinaca sativa

Secale cereale

Vitis vinifera

Possible cultivated plants

Allium type

Cannabis type

Weeds and other wild plants

Anthemis type

Apiaceae (undiff.)

Artemisia

Aster type

Asteraceae-Liguliflorae

Brassicaceae

Calluna vulgaris

Caryophyllaceae

Centaurea cyanus

Centaurea nigra type

Chelidonium majus

Chenopodiaceae

Convulvulus arvensis

Cyperaceae (undiff.)

Ericaceae (undiff.)

Filipendula

Galium type

\begin{tabular}{|c|c|c|c|c|c|c|}
\hline 67 & 10.2 & 88 & 14.9 & 51 & 8.6 & alder \\
\hline \multirow[t]{2}{*}{10} & 1.5 & 8 & 1.4 & 17 & 2.9 & birch \\
\hline & & & & 1 & 0.2 & hornbeam \\
\hline \multirow[t]{2}{*}{12} & 1.8 & 11 & 1.9 & 13 & 2.2 & hazel \\
\hline & & 3 & 0.5 & & & beech \\
\hline 1 & 0.2 & 1 & 0.2 & & & alder buckthorn \\
\hline \multirow[t]{3}{*}{10} & 1.5 & 9 & 1.5 & 3 & 0.5 & ash \\
\hline & & & & 1 & 0.2 & ivy \\
\hline & & 1 & 0.2 & 2 & 0.3 & apple type \\
\hline 6 & 0.9 & 5 & 0.8 & 6 & 1 & pine \\
\hline 108 & 16.5 & 108 & 18.3 & 91 & 15.4 & oak \\
\hline 2 & 0.3 & 4 & 0.7 & & & willow \\
\hline 2 & 0.3 & 2 & 0.3 & 4 & 0.7 & elder type \\
\hline \multirow[t]{2}{*}{2} & 0.3 & & & & & yew \\
\hline & & 2 & 0.3 & 2 & 0.3 & lime \\
\hline 3 & 0.5 & 2 & 0.3 & 9 & 1.5 & elm \\
\hline 223 & 34.0 & 244 & 41.3 & 200 & 33.8 & arboreal pollen \\
\hline
\end{tabular}

\begin{tabular}{|c|c|c|c|c|c|c|}
\hline & & & & 1 & 0.2 & chervil \\
\hline & & & & 1 & 0.2 & borage \\
\hline 56 & 8.5 & 38 & 6.4 & 65 & 11.0 & cereals \\
\hline 13 & 2.0 & 3 & 0.5 & 5 & 0.8 & buckwheat \\
\hline & & 1 & 0.2 & & & parsnip \\
\hline 13 & 2.0 & 6 & 1.0 & 33 & 5.6 & rye \\
\hline 1 & 0.2 & & & 1 & 0.2 & grape \\
\hline
\end{tabular}

$\begin{array}{lllllll}5 & 0.8 & 9 & 1.5 & 2 & 0.3 & \text { onion type } \\ \text { hemp type }\end{array}$

$\begin{array}{lllllll}2 & 0.3 & 1 & 0.2 & 4 & 0.7 & \text { chamomile type }\end{array}$

$\begin{array}{lllllll}7 & 1.1 & 4 & 0.7 & 19 & 3.2 & \text { carrot family }\end{array}$

$\begin{array}{lllllll}8 & 1.2 & 6 & 1 & 3 & 0.5 & \text { mugwort }\end{array}$

$\begin{array}{lllllll}12 & 1.8 & 6 & 1 & 3 & 0.5 & \text { aster type }\end{array}$

$\begin{array}{lllllll}5 & 0.8 & 10 & 1.7 & 6 & 1 & \text { chicory family }\end{array}$

$\begin{array}{lllllll}15 & 2.3 & 6 & 1 & 4 & 0.7 & \text { cabbage family }\end{array}$

$\begin{array}{lllllll}2 & 0.3 & 1 & 0.2 & 1 & 0.2 & \text { heather }\end{array}$

$\begin{array}{lllll}3 & 0.5 & 1 & 0.2 & \text { pink family }\end{array}$

$\begin{array}{lllllll}4 & 0.6 & 4 & 0.7 & 3 & 0.5 & \text { cornflower }\end{array}$

$\begin{array}{lllllll}2 & 0.3 & 5 & 0.8 & 1 & 0.2 & \text { common knapweed }\end{array}$

$\begin{array}{lllllll}5 & 0.8 & 5 & 0.8 & 2 & 0.3 & \text { greater celandine }\end{array}$

$\begin{array}{lllllll}5 & 0.8 & 5 & 0.8 & 8 & 1.4 & \text { goosefoot family } \\ & & & & 1 & 0.2 & \text { field bindweed }\end{array}$

$\begin{array}{llllll}4 & 0.6 & 4 & 0.7 & \text { sedge family }\end{array}$

heather family

meadowsweet

bedstraw type 
TABLE 11 (Continued)

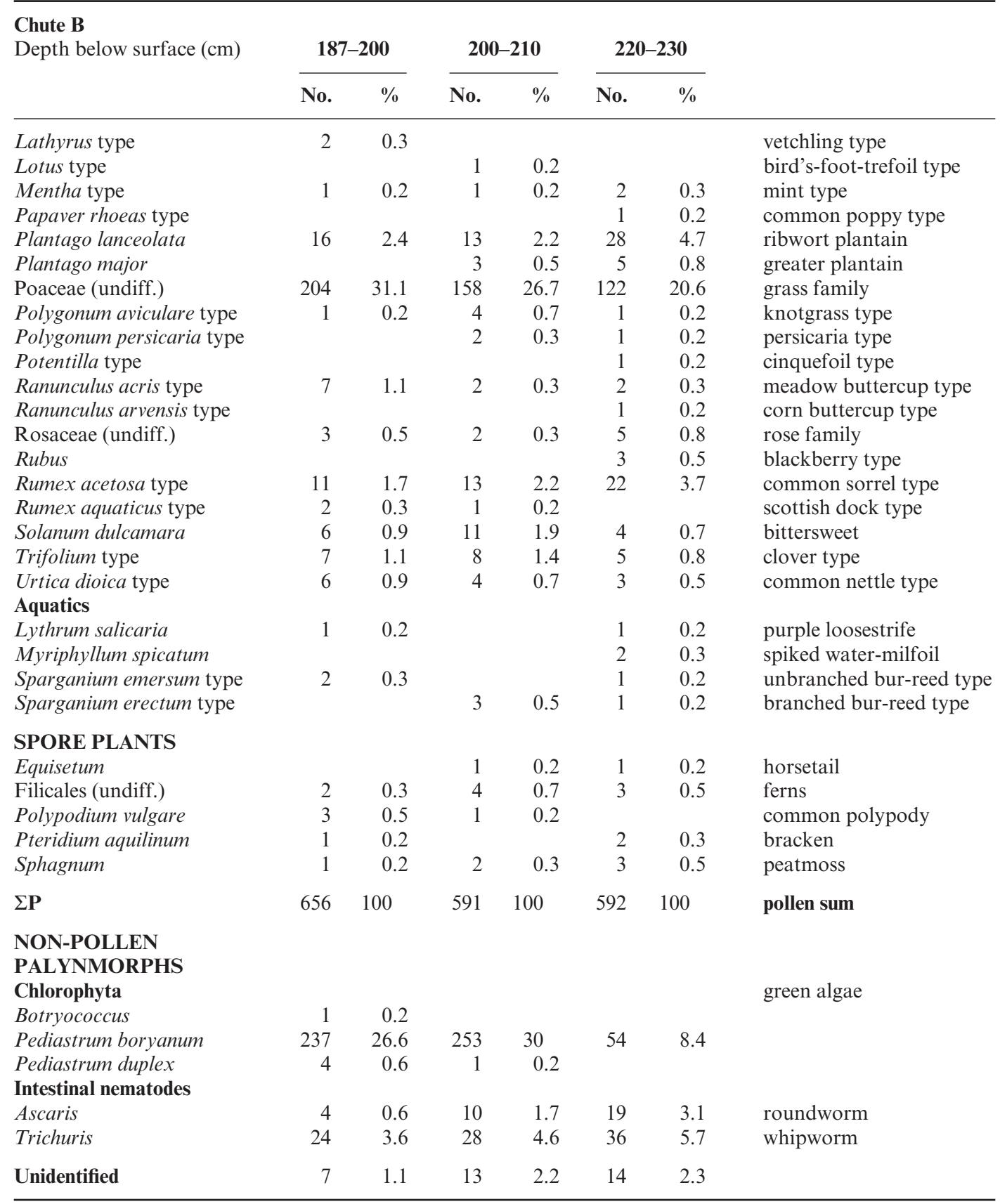

Percentages based on sum of all pollen types $(\Sigma \mathrm{P})$, including aquatics but excluding other palynomorphs like green algae and intestinal parasite ova.

Percentages of green algae and intestinal parasite ova based on sum of all pollen types and palynomorphs considered $(\Sigma \mathrm{P}+\mathrm{X})$. 

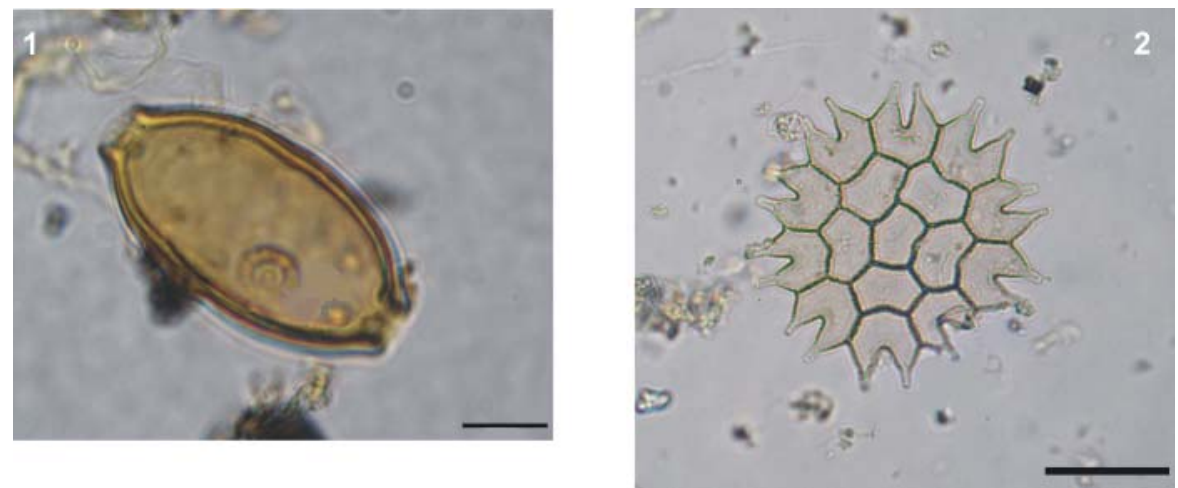

FIG. 21

Middelburg castle, chute B outflow. 1. whipworm egg (Trichuris sp.) (scale bar=10 micrometer); 2. Pediastrum boryanum colony (scale bar $=30$ micrometer).

Hemp is cultivated for its fibres, and as several seeds of hemp were found in the same samples, it is likely that the pollen found belongs to hemp. Hop is native in Flanders and was (and still is) cultivated for flavouring beer. ${ }^{211}$

All samples investigated contained ova of the parasitic intestinal worms Trichuris (whipworm) and Ascaris (roundworm). Whipworm species can infest most mammals, man included. Roundworm is mainly known in pigs and man. ${ }^{212}$ Humans are infected through the ingestion of contaminated water or food like uncooked vegetables and fruit grown in or near soil fertilized with sewage. Whipworm infection does not cause serious symptoms in humans. Neither does roundworm infection normally lead to medical problems, although a large number of roundworms can result in pneumonitis. ${ }^{213}$ Whipworm and roundworm ova are commonly found in medieval and post-medieval cesspits and waste deposits. ${ }^{214}$

The aquatic component is attested by pollen from aquatic plants and by the green algae Botryococcus and Pediastrum; huge amounts of the last were identified (Fig. 21:2). The aquatic plants are purple loosestrife (Lythrum salicaria), spiked water-milfoil (Myriophyllum spicatum), unbranched bur-reed type (Sparganium emersum type) and branched bur-reed type (Sparganium erectum type). The first two grow on the margins of ponds and rivers and in shallow water. The last two grow in slightly deeper water. All these plants must have been part of the vegetation in the moat. They grow in mesotrophic and eutrophic water; branched bur-reed is especially tolerant of eutrophication. ${ }^{215}$

Pediastrum and Botryococcus are green algae that produce a sporopollenin-like substance in their cell walls as a consequence of which they are well preserved and can be recognized in pollen analysis. ${ }^{216}$ The considerable number of green algae, especially Pediastrum boryanum, in the outflow samples indicates that the water in the moat was polluted. Large concentrations of algae in a water body are called algal bloom and give the water a green colour. In very large concentrations, it might make the water look like a mass of thick green scum. These algal blooms are caused by a combination of factors such as warm temperatures, light and the presence of nutrients. ${ }^{217}$ The most important nutrient for green algae is nitrogen. As faecal material contains a lot of nitrogen, it is likely that the algal bloom was triggered by the chute outflow. As water fleas (Daphnia) mainly feed on algae, the quantity identified during the macrobotanical analysis may be explained by the algal bloom.

Most of the pollen from trees and shrubs and some of the herbs that was found in the outflow originates from the vegetation surrounding the castle and derived from the natural pollen rain on the moat. Some of this pollen could, however, be part of the chute component as well, especially the arable weed pollen from cornflower (Centaurea cyanus) and the common poppy (Papaver rhoeas type), which are typical of cesspit pollen spectra. ${ }^{218}$ Pollen of these plants is, just like their seeds, harvested and processed together with the cereals and incorporated in bread, porridge and other food derived from cereals.

\section{CONCLUSION}

The presence of pollen of food plants and their associated weeds, together with high amounts of intestinal parasite ova, demonstrate clearly the 
presence of faecal material in the outflow of the chute into the moat. The palynological investigation also added some taxa to the list of food plants found during the macrobotanical analysis, such as chervil, borage and parsnip. In most other late- and post-medieval cesspits from Flanders, several exotic pollen types like cloves (Syzygium aromaticum) or crimson spotted rockrose (Cistus ladanifer type) have been found..$^{219}$ Their absence here may reflect the troubled political situation, which limited access to imported products. On the other hand, the aquatic plant pollen and the high amounts of green algae of the genus Pediastrum indicate the eutrophication of the water in the moat, most probably caused by the influx of sewage.

\section{ANTHRACOLOGICAL ANALYSIS}

\section{By KOEN DEFORCE}

\section{INTRODUCTION}

Charcoal fragments have been identified in order to obtain some information on the former woody vegetation near the castle. They were recovered from the sieved residues $(5 \mathrm{~mm})$ of the same samples analysed for animal bones and macrobotanical remains. One hundred and fifty and 218 charcoal fragments have been recovered and identified respectively from chutes A and B.

\section{RESULTS (Table 12)}

As there is little difference between the results of the sampled spits within each of the chutes, only the total assemblage of each chute is given. There is also little difference in the charcoal assemblage of the two investigated chutes. Oak (Quercus sp.) is the dominant charcoal type in both $\mathrm{A}(56 \%)$ and $\mathrm{B}$ $(58.3 \%)$, followed by alder (Alnus sp.), birch (Betula sp.) and willow (Salix sp.). Small amounts of hazel (Corylus avellana), ash (Fraxinus excelsior) and poplar (Populus sp.) have also been found in both chutes. Lime (Tilia sp.) and elm (Ulmus sp.) was only found in chute A and Norway spruce (Picea abies), sweet cherry type (Prunus avium type), sloe type (Prunus spinosa type), elder (Sambucus sp.) and a few fragments of charred bark in chute B.

\section{DISCUSSION}

Except for Norway spruce (Picea abies), all the taxa found in the chutes could have grown near the castle, but not all at the same location. Alder, ash, poplar and willow grow on damp or wet soils while oak, lime and elm prefer drier habitats, and birch
TABLE 12

Middelburg castle. Anthracological analysis.

\begin{tabular}{|c|c|c|c|c|c|}
\hline & \multicolumn{2}{|c|}{ Chute A } & \multicolumn{2}{|c|}{ Chute B } & \\
\hline & No. & $\%$ & No. & $\%$ & \\
\hline Alnus sp. & 33 & 22 & 39 & 17.9 & alder \\
\hline Betula sp. & 10 & 6.7 & 14 & 6.4 & birch \\
\hline Corylus avellana & 3 & 2 & 4 & 1.8 & hazel \\
\hline Fraxinus excelsior & 5 & 3.3 & 7 & 3.2 & ash \\
\hline Picea abies & & & 1 & 0.5 & $\begin{array}{l}\text { Norway } \\
\text { spruce }\end{array}$ \\
\hline Populus sp. & 1 & 0.7 & 4 & 1.8 & poplar \\
\hline Prunus avium type & & & 1 & 0.5 & $\begin{array}{l}\text { sweet } \\
\text { cherry type }\end{array}$ \\
\hline $\begin{array}{l}\text { Prunus spinosa } \\
\text { type }\end{array}$ & & & 2 & 0.9 & sloe type \\
\hline Quercus sp. & 84 & 56 & 127 & 58.3 & oak \\
\hline Salix sp. & 9 & 6 & 15 & 6.9 & willow \\
\hline Sambucus sp. & & & 2 & 0.9 & elder \\
\hline Tilia sp. & 1 & 0.7 & & & lime \\
\hline Ulmus sp. & 4 & 2.7 & & & elm \\
\hline Bark & & & 3 & 1.4 & bark \\
\hline TOTAL & 150 & 100 & 218 & 100 & \\
\hline
\end{tabular}

grows on both wet and dry soils. Norway spruce is native to north and central Europe and does not occur naturally in Western Europe. ${ }^{220}$ It was introduced in Belgium for timber production in the middle of the last century, ${ }^{221}$ but Norway spruce was imported as construction material since at least the 16th century. ${ }^{222}$ It was also used to make furniture, ladders and tools. ${ }^{223}$ It has been found in late-medieval sites in Raversijde and Groningen in the Netherlands. ${ }^{224}$

Oak may be overrepresented in the charcoal assemblage. As it has a higher calorific value than most other European woods, it makes an excellent fuel. ${ }^{225}$ Most of the other taxa found produce fuel of a lower quality. They were probably more abundant, grew closer to the castle, or were available as disused building material or discarded wooden objects, which was probably the case with the Norway spruce fragment.

\section{INTERPRETATION}

\section{By WIM DE CLERCQ, ANTON ERVYNCK and KOEN DE GROOTE}

As similar well-dated contexts in the region are not yet available, socio-economic interpretation has to be based almost entirely on the evidence at Middelburg. 
The fill of the two structures shows a remarkable similarity, both in terms of the general nature of their contents and of the frequencies of items within the different finds groups, which point to a similar pattern of refuse disposal. The cross-fitting of fragments derived from different levels, the lack of stratification in the chutes, and their abrupt sealing by a thick layer of building debris indicate that the fills represent the material evidence of a single event or a short period of deposition. However, the finds vary in date showing that residual material - which was on the whole more fragmented - formed part of the fill. Thus, part of the chutes' contents had apparently already been deposited elsewhere, perhaps as part of refuse heaps or other forms of temporary waste accumulation nearby. If some is secondary refuse, then some of the biological evidence for the preparation and consumption of food may too reflect earlier behaviour. The botanical macroremains, pollen and the intestinal parasite eggs indicate human excrement and confirm the use of the chutes as latrines. Although this part of the chutes' contents could have been deposited together with the secondary refuse, it is more likely that they result from the prolonged use of the shafts as part of the castle's latrine system.

The artefacts indicate a late 16th- to early 17 th-century date for the filling of the chutes. A coin from chute A provides a terminus post quem of 1557 for its fill. The pottery suggests a deposition date in the second half of the 16th century for both chutes, while some ceramic finds point to the very end of the century or to the beginning of the next one. The glass vessels offer a similar picture, although there are some older items in chute $\mathrm{A}$ and some belong to the early 17 th century in chute B. However, since the latter are unusual types, which may reflect a specific social behaviour, their absence in chute $\mathrm{A}$ is not conclusive evidence that chute $\mathrm{A}$ was filled earlier.

Alongside the human excrement, it seems that the contents of the chutes are the result of a single operation, including both old and new rubbish. An extensive clean-up of parts of the castle, removing old refuse as well as objects no longer wanted could account for the picture reflected in both contexts. In any case, both waste fractions point to the deliberate filling-up of the shafts at a specific moment or over a short period of time. Interestingly, the chutes were never cleaned afterwards and their fills were immediately covered with building debris derived from the castle. That the deposits below contained similar construction debris, though in a lower frequency, suggests that the main structure of the roof, walls and windows as well as fittings such as the fireplaces and stoves of the upper court were already damaged or that the castle was no longer in continuous use or properly maintained. The sediments were probably deposited shortly before the complete destruction or demolition of the entrance tower and the southern corner tower which formed the facade of the upper court. The chronology of the archaeological evidence matches that of the written evidence describing the events when this part of the upper court may well have undergone a drastic change. The historical sources point to two major moments of intensive destruction of the city and castle, in 1583 by English troops and in 1604 by Dutch and Spanish forces in a period of violent conflict between 1578-1590/1604. After 1604, the castle was not attacked again and the documentary evidence indicates that around 1610 the southern part of the castle's upper court, where the garderobe chutes were located, must have been replaced by earthworks.

It can be argued that the finds reflect the high status of the castle's occupiers when the chutes were filled. As war at this time was characterized by the breakdown of economic networks, expressing status through the consumption of food and material objects could not have been easy. Yet the finds provide several indications of elite consumption. For instance, the comparison of the glass with other contemporary assemblages from high-status sites abroad shows that a similar set of utilitarian and luxury vessels was in use at Middelburg. Some uncommon or unique forms like the drinking boots are clearly related to military officers. The quantity of luxury drinking and table glass points to convivial drinking within a castle setting. The study of the pottery reveals an unusually high number of small-volume cooking pots ('jars') and skillets, which may reflect the preparation and consumption of individual portions, expected in a military context. The unparalleled high frequency of gallipots may have been used to treat the wounded. The lead shot and waste may be the most direct evidence of troops, as they prove the production of ammunition for pistols and heavier firearms. In contrast, the spindle whorls, lead/tin alloy toys and porringers decorated with religious texts may have been civilian possessions belonging to earlier occupants, refugees or camp followers or have been looted. The disposal of this mostly intact material could also reflect other processes, such as the cleaning-up of a room used by previous occupiers. On the whole, our interpretation of the material culture fits the historical evidence. At this time, the castle had lost its elite, noble character, because it had become an important target in the SpanishDutch religious wars. Between 1578 and 1609 various military units were encamped in Middelburg castle. There was, however, a civilian intermezzo from 1590 to 1604 , when poor farmers, an innkeeper and a bailiff and their families occupied the site. 
The diet of the castle's inhabitants in the second half of the 16th and early 17 th century, revealed by the study of the environmental data, may confirm the high status of at least some of the occupants as reflected by the other finds. The high frequency and variety of hunted birds could in particular support this interpretation. These hunted birds must have been of local origin, which leaves the question open whether their consumption was out of necessity (which would merely point to subsistence needs) or to satisfy the desire for a varied diet (which may reflect a higher status). However, a combination of both explanations is possible: an elite selection of food items were selected from a supply limited in quantity and quality by the prevailing conditions. The high number of freshwater fish of local origin underlines that most of the food items had to be purchased, gathered, requisitioned or looted in the vicinity. That most of the marine fish is of coastal origin reflects the dangers and prohibitions limiting open-sea fisheries at the time. This more-or-less self-sustaining system is supported by the description of Middelburg in the 1600s. Troops were said to have pastured cattle and other animals and sheltered them in local buildings, whereas the enemy engaged in cattle raiding. ${ }^{226}$ Contemporary sources also state that, by the end of the 16th century, when the Scheldt estuary was blocked by the Dutch, the Spanish Army of Flanders had to rely completely on local sources for provisioning and supply. ${ }^{227}$ The animal assemblage pattern probably does document a food supply which was regionally based out of necessity, but which still retained elements of status. As well, the presence and diversity of some exotic and perhaps luxury plants point to a wealthier menu for at least some consumers. All in all, the evidence suggests that the food economy was limited by the circumstances, but that this did not prevent some of the castle occupiers from maintaining their social rank.

\section{CONCLUSION}

Both chutes were filled in a single operation or over a short period of time towards the end of the 16th or the beginning of the 17th century with both primary and secondary refuse. The intense military presence in the castle between 1578-90 and 1604 09 , recorded in detail in the written sources, is confirmed by the artefacts found. Although the economy and landscape were disrupted, social distinctions seem to have been more or less maintained, even if consumption had to be based more on local supplies than was usual in higher-status households. Soon after the deposition of the refuse in the chutes, the front side of the upper court was damaged or destroyed and its debris filled the rest of the garderobe shafts. In view of the archaeological dating, the military character of most of the artefacts and the historical information, a date for the filling of both chutes lies most likely after 1578 and before 1609 .

\section{ACKNOWLEDGEMENTS}

The authors thank Piet and Paul Blomme, Paul Verstraete, Boudewijn De Schepper, Eline Deweirdt, John Calmeyn, Ine De Graeve, Senne Diependaele, Elise Martens, Carolien Van Loon, Nele Vanholme, Joke Sedeyn and Birger Stichelbaut for their assistance during the excavations; Nathalie Cleeren (FHI) and Nicole Minten for consolidating and restoring the glass; Johan Veeckman (Antwerp Archaeological Service) for his help in the identification of the Low Countries maiolica; Paul Courtney for sending us information on siege archaeology and lead shot; Roger Schockaert and Anja Sprangers (FHI) for sieving the samples. Drawings were made under difficult circumstances by Rob Vanschoubroek and Jan Moens of the ceramics and Marc Van Meenen of the glass and metal finds (all FHI). Pictures of objects were taken by Hans Denis (FHI). Dr James Greig (Birmingham, UK) corrected the English and gave useful comments on the fruits and seeds contribution. Luc Muylaert (FHI) and Wim Wouters (RBINSc) assisted in the archaeozoological analysis. The contribution of Wim Van Neer to this paper presents research results of the Interuniversity Attraction Poles Programme - Belgian Science Policy. The editors thank David Bolton, Geoff Egan, Jacqui Pearce and Hugh Willmott for checking the terminology of the sections on the environment, small finds, ceramics and glass.

\section{NOTES}

${ }^{1}$ A programme of excavation and presentation was carried out by the community of Maldegem, the Flemish Community (Monumenten \& Landschappen and Flemish Heritage Institute), the province of East Flanders and the University of Ghent.

${ }^{2}$ This section summarizes De Clercq et al. 2007.

${ }^{3}$ From 1280 the small rural estate of hof van Middelburg in the parish of Heile, owned by the abbey of Middelburg-in-Zeeland (Holland), preceded the New Town. The founder Bladelin kept the name Middelburg and added the suffix 'in-Flanders', to distinguish it from the other Middelburg on Walcheren Island in present-day Dutch Zeeland.

${ }^{4}$ De Lettenhove 1844, 44.

${ }^{5}$ Berlin, Staatliche Museen, Preussischer Kulturbesitz, inv. no. 535. 
${ }^{6}$ Van Vooren 1987.

7 Verschelde 1867; Martens 2004.

${ }^{8}$ Raad Van Vlaanderen, BDL 448 (kindly transcribed by Willy Stevens). This recently discovered report of hearings before the court of the Council of Flanders in 1632 recorded the testimony of witnesses to the situation in Middelburg in c. 1600. Some creditors had sued the lord of a nearby castle for not settling his debts. He called twelve witnesses, including former soldiers and the bailiff of Middelburg castle, to testify to the disastrous impact of the military occupation in the years around 1600 had on the land and hence on his profits.

${ }^{9}$ The following section is based on the detailed studies by Verschelde 1867, Van Vooren 1987 and Martens 2004 and on Raad Van Vlaanderen, BDL 448.

10 'de meeste landerijen, hagen en bossen zijn verdronken door het zout water door het doorsteken van de dijken nabij de belegerde stad en kasteel van Sluis', State Archives in Ghent, Middelburg, no. 15.

${ }^{11}$ Raad Van Vlaanderen, BDL 448.

12 'te sijne eene van den schoonste, grootste ende principaelste heerlickheden die het bestrecken ende resorteren onder den lande van den Vrijen ... Tot sulck een desolatie ende destructue gecommes es ... ghereed om gedemanteleert te wesen . . . . een steen up den anderen daer bynaer niet en es bleven . . . ligghende gemeene met de see seer beclaeghelick ende jammer om siene', State Archives in Ghent, Fonds Maldegem Ambacht, charters Maldegem and Middelburg, charter of 26 March 1607; Gilliodts-Van Severen 1891, 222-3.

${ }^{13}$ Raad Van Vlaanderen, BDL 448.

14 Bauwens \& De Vries 2004.

${ }^{15}$ Cited in Verschelde 1867, 119.

${ }^{16}$ State Archives in Ghent, uncatalogued files.

${ }^{17}$ Archives de l'Armée de Terre, Vincennes (France), Fonds Midelbourg, 14.

${ }^{18} \mathrm{New}$ earthworks were raised at the beginning of the 18th century by the Dutch military engineer Coehoorn or by the French following the Vauban system.

${ }^{19}$ For more information on the excavation results, see De Clercq, Mortier \& Pype 2004.

${ }^{20}$ Verschelde 1867, 34.

${ }^{21}$ Martens 1997.

${ }^{22}$ The drum towers were $12.5 \mathrm{~m}$ in diameter and built of $2.30 \mathrm{~m}$-thick masonry.

${ }^{23}$ Context $02 / \mathrm{mika} /$ sampling levels $15-35$.

${ }^{24}$ Context 03/mika/ sampling levels 33-46.

${ }^{25}$ Verhaeghe 1997, 23-4; Hillewaert \& Verhaeghe 1991, 211, fig. 172:2-3.

${ }^{26}$ Bungeneers 1992, fig. 5:3; Hillewaert \& Verhaeghe 1991, fig. 172:5; Lettany et al. 1992, fig. 7:6; De Groote 1993, fig. 19:2; De Groote et al. 2004, fig. 38:1-5.
${ }^{27}$ De Groote 2005, 255-9.

${ }^{28}$ De Groote 2005, 221-9.

${ }^{29}$ Swimberghe 1983-84, 185, fig. 7. The published text is: Memento (Mori?), but $O$ M[ater Dei] MEMENTO M[ei] can be read on the drawing.

${ }^{30}$ Hurst et al. 1986, 153, pl. 25.

${ }^{31}$ De Groote 1993, 354, fig. 25:1.

${ }^{32}$ Veeckman et al. 1992, fig. 13:2; De Groote et al. 2004, 313-14; Van Eenhooge 1999, fig. 9:86.

${ }^{33}$ Groeneweg 1987; Swinnen 1989.

${ }^{34}$ Pieter van der Heyden, Patience, 1557; Unchastity, 1558; Pieter Brueghel the Elder, Mad Meg, 1557;

The Census at Bethlehem, 1566 (Roberts-Jones \& Roberts-Jones 1997, 81; figs 88, 100:1, detail figs 102 , 181).

${ }^{35}$ We thank Johan Veeckman (Antwerp Archaeological Service) for checking our identifications.

${ }^{36}$ Veeckman \& Dumortier 1999, cat. 40-5 (form); 8, 50 (decoration).

${ }^{37}$ Veeckman 1999, fig. 6:14.

${ }^{38}$ Veeckman \& Dumortier 1999, cat.11-22 (form); 23 (decoration).

${ }^{39}$ Reineking-Von Bock 1971, 78; Vandenbulcke \& Groeneweg 1988, 346, figs 7-11; Hurst et al. 1986, fig. 95:311; Gaimster 1997, 225.

${ }^{40}$ Reineking-Von Bock 1971, figs 285-6, 289; Gaimster 1997, 192, fig. 37; for the Frechen production of that period, see p. 210.

${ }^{41}$ Hurst et al. 1986, 198, fig. 94:306.

${ }^{42}$ Vandenbulcke \& Groeneweg 1988, 346, figs 7-11; De Groote 1993, 358-9; De Groote 2005, 388-92.

${ }^{43}$ In England most whorls date from the late 15th and early 16th century, Hurst et al. 1986, 206, figs 100:318-20; Gaimster 1997, 225, 248-50, cat. 104. In Bergen-op-Zoom in the Netherlands they were present in the stock of a stoneware merchant of the second quarter of the 16th century (Vandenbulcke \& Groeneweg 1988, 355, fig. 10:83-5), and at Aalst in a contemporary cesspit (De Groote et al. 2004, fig. 53:8).

${ }^{44}$ Hillewaert \& Verhaeghe 1991, fig. 173:8.

${ }^{45}$ Bartels 1999, 696, cat. 606.

${ }^{46}$ Gaimster 1997, 225, cat. 85-91; Hurst et al. 1986, 194, pl. 35, figs 94:309, 96:313.

${ }^{47}$ Hurst et al. 1986, 22; Gutiérrez 2000, 90-1.

${ }^{48}$ Hurst et al. 1986, 22-3, fig. 8:13; Clevis \& Thijssen 1989, 16-17, cat. 134; Bartels 1999, 226, cat. 1109.

${ }^{49}$ No matching sherds were found linking the two chutes.

${ }^{50}$ In a large 16th-century cesspit at Aalst, containing about 250 vessels, no frying pan or lid was found (De Groote et al. 2004, 341, table 2).

${ }^{51}$ The Aalst cesspit contained 68 chamber pots (De Groote et al. 2004, table 2).

${ }^{52}$ De Groote 1993, 376.

${ }^{53}$ About 40 glass beakers and cups and only five stoneware beakers and jugs were found in a late 
16th-century cesspit, containing 183 ceramic and glass vessels, within the noble Hoogstraten court in Brussels (Van Eenhooge 1999).

${ }^{54}$ An early 16th-century waste layer in the Beaulieu Convent at Petegem contained oil jugs and oil pots associated with other indications of wool and textile production, such as needles, iron scissors and thimbles (De Groote 1993, 359-60, 386, 405). The large number of older sheep bones indicated that they were bred for milk and/or wool production (Ervynck \& Van Neer 1993, 391-3).

${ }^{55}$ The glass finds from the 2002-03 excavation were assessed by Caluwé 2005c. A complete report, including those found in the 2004 excavation, is in preparation.

${ }_{56}^{56}$ Caluwé, forthcoming d.

${ }^{57}$ Caluwé, forthcoming e.

${ }^{58}$ From Diest (Caluwé 2004), Antwerp: Steen (Caluwé 2000), Stoofstraat (Caluwé, forthcoming d) and Kaasstraat (Denissen 1984, 14, fig. 2:31; 16, fig. 4:569), and in Brussels: Place St Catherine (late 16th to early 17th century, Fontaine \& Degré 1995, 140, fig. 100:34-5; 151, fig. 103), rue de Dinant (second half of the 17th century, Fontaine 2001, 228-9, fig. 18:4; 231, fig. 3).

${ }_{59}$ Tyson 2005, 55.

${ }^{60}$ Henkes 1994, 167.

${ }^{61}$ Caluwé, forthcoming d.

${ }^{62}$ Denissen 1984, 41, 51.

${ }^{63}$ Caluwé 2000.

${ }^{64}$ Caluwé, forthcoming d.

${ }^{65}$ Henkes 1994, 189-92.

${ }^{66}$ Caluwé 2000; 2005a; 2005b.

${ }^{67}$ Steen (Caluwé 2000), Kaasstraat (Denissen 1984, 41, cat. 47, fig. 18), Bisschoppelijk Paleis (Henkes 1994, 204, cat. 46:6), Waterkerende muur (Denissen 1982, 180, cat. 468c, pl. 5:486c), collection Van de Walle (Denissen 1982, cat. 468b), Huis Halmale, Venusstraat (Denissen 1985, 36, cat. 9:12, fig. 9:52).

${ }^{68}$ Caluwé, forthcoming b.

${ }^{69}$ Caluwé, forthcoming c.

${ }^{70}$ Fontaine 2002, 418-19, figs 4-6.

${ }^{71}$ Van Eenhooge 1999.

${ }^{72}$ Caluwé, forthcoming b.

${ }^{73}$ Michel Hulst, pers. comm.

${ }^{74}$ Willmott 2002, 63.

${ }^{75}$ Henkes 1994, 96; 2002.

${ }^{76}$ Henkes 1994, 96; Chambon 1955, 310.

${ }^{77}$ Henkes 1994, 100, cat. 24:4.

${ }^{78}$ De Clippele-De Bleser 1988, 145-7, fig. 101:12.

${ }^{79}$ Caluwé, forthcoming d.

${ }^{80}$ Caluwé, forthcoming d.

${ }^{81}$ Guilhot \& Munier 1990, 168, fig. 8:28, pl. 8B.

${ }^{82}$ Ritsema van Eck \& Zijlstra Zweens 1995, 52.

${ }^{83}$ Gevaert et al. 2003, cat. 65 .

${ }^{84}$ Caluwé, forthcoming d.

${ }^{85}$ Caluwé, forthcoming b.
${ }^{86}$ Ring 2003, 134, cat. 3:035.

${ }^{87}$ Henkes 2002.

${ }^{88}$ Henkes cites von Saldern 1965, 178.

${ }^{89}$ Postelstraat, Jacobs \& Graas 1983, 240-2, figs $8 \mathrm{a}-\mathrm{b}, 15 \mathrm{a}-\mathrm{b}$.

${ }^{90}$ Willmott 2002, 25.

${ }^{91}$ Caluwé 2005c.

${ }^{92}$ Dreier 1989, 68, with references to parallels.

${ }^{93}$ Klesse 1973, 134, no. 248.

${ }^{94}$ Mosel 1979, 57-8.

${ }^{95}$ Caluwé, forthcoming c.

${ }^{96}$ Late 15 th to early 16 th century, Rieb 1972,128 , fig. 20 .

${ }^{97}$ Tyskebryggen, G. Haggrèn, pers. comm.

${ }^{98} \mathrm{H}$. Willmott, pers. comm.

${ }^{99}$ Freundschaftsbecher, Dreier 1989, 67.

${ }^{100}$ Caluwé, forthcoming $b$.

${ }^{101}$ Caluwé 2006.

${ }^{102}$ Ritsema Van Eck \& Zijlstra Zweens 1993, 76, no. 99 .

${ }^{103}$ Henkes 1994, 205, cat. 46:8.

${ }^{104}$ Caluwé, forthcoming a.

${ }^{105}$ Henkes 1994, 205; Duysters 2002, 113, fig. 26; Liefkes 2002.

${ }^{106}$ Caluwé, forthcoming d.

${ }_{107}$ Velde 2002; Steppuhn 2003; Willmott 2002, 57-8.

${ }^{108}$ For a full report on all the window glass found in Middelburg, see Wouters, forthcoming.

${ }^{109}$ Devliegher 1990, 100.

110 e.g. at Eindhoven castle, Arts 1992a, 106.

${ }^{111}$ Wouters 2001.

${ }^{112}$ Crown glass (bull's eye pane): flat glass made by the process of blowing a bubble of glass, transferring it from the blow pipe to a rod, cutting it open, then rapidly rotating it, with repeated reheating, until by centrifugal force the glass spreads into a large disk $1.2 \mathrm{~m}$ in diameter. Because most of the glass was severely weathered, it was difficult to determine the production method.

${ }^{113}$ Cylinder glass (broad glass, muff glass): flat glass made by the process of blowing a large glass bubble and swinging it on the blow-pipe to form a large bottle. Both rounded ends were then cut off and the resulting cylinder or muff, up to $1.5 \mathrm{~m}$ in length, was then cut lengthwise and flattened. Two fragments of this type were found in chute A (glass inv. 63, 65) and one in chute B (glass inv. VG85).

${ }_{114}$ Moran 2005, 145.

${ }^{115}$ Chute A, glass inv. 263.

${ }^{116}$ Chute A, glass inv. 246.

${ }_{117} 23$ pieces or $5 \%$ of the total surface.

${ }_{118}$ Wouters 2001, 128-30. The dating of window glass by its chemical composition is being investigated by Dr O. Schalm and Prof. Dr K. Jansens of the University of Antwerp who are analysing 300 samples, including ten pieces from Middelburg, dating from the 12 th to the 17 th century. 
${ }^{119}$ Hupperetz 2004, 143-4.

${ }^{120}$ Rodwell \& Bell 2004, 263.

121 Janse 1971, 58. Confirmed at Antwerp (Wouters 2001) and Raversijde (Gevaert et al. 2003).

${ }^{122}$ Wouters 2001, 31-43.

${ }^{123}$ Aardenburg (the Netherlands): 14th and 15th century, Raversijde (Belgium): 15th century (Gevaert et al. 2003), Antwerp: 16th century (Wouters 2001, 65-86).

${ }^{124}$ Offmann \& Schneider 2001.

${ }^{125}$ Chalmin-Sirot 2001.

126 cf. Arts 1992a, 106.

127 e.g. Marie \& Schwien 2000.

${ }^{128}$ Similar finds from Eindhoven castle are of Rhenish provenance, Arts 1992a, 106.

${ }^{129}$ Van Gelder \& Hoc 1960, 229.

${ }^{130}$ Van Gelder \& Hoc 1960, 229.

131 Van der Linden 1994, 39.

${ }^{132}$ Courtney 2004, 390-1.

${ }^{133}$ IHS was interpreted erroneously as a monogram for In Hoc Signo (vinces), 'in this sign you will overcome', Blake et al. 2003, n. 4.

${ }^{134}$ e.g. Egan 2005, fig. 28:168; Arts 1992b, 171.

135 Willemsen 1998, 370-7, figs B52, B67, B72.

${ }^{136}$ For fuller discussions of these lead-tin alloy toys, see Willemsen 1998; Egan 1998, 281.

${ }^{137}$ Musacchio 2000, 147-55. I owe this reference to Hugo Blake.

${ }^{138}$ H. Hendrikse (Foundation for Cultural Heritage Zeeland) drew our attention to identical finds from Sluis in a context dated to the end of the 16th century.

139 Everaert 2003a.

140 'los muchahos hazian o tenian unos sacramentillos' and added 'qui es diminutivo de sacramento', Everaert 2003a, 289; 2003b.

${ }^{141}$ Everaert 2003a, 292.

${ }^{142}$ Courtney 1993, 159, describes a similar distribution pattern at Beeston castle in Cheshire.

${ }^{143}$ Luc Muylaert (FHI) helped with the initial sorting of the sieved residues. Identification of molluscs, amphibian bones and most of the fish remains was undertaken by Wim Wouters (RBINSc).

${ }^{144}$ Boessneck et al. 1964.

${ }^{145}$ See Ervynck et al. 1994 for a discussion of the taphonomy of animal remains in a cesspit shaft.

${ }^{146}$ See Van Damme \& Ervynck 1988 for an overview of the natural history of the rabbit in the Low Countries, which takes into account that a 12 th- to 13th-century date for the introduction of the animal is no longer certain (Ervynck 2003). An early indication of certainly domesticated rabbit comes from 17thcentury deposits at Tongeren (Wouters et al. 1994).

${ }^{147}$ The discrimination between the greylag goose and its domestic form, the domestic goose, can only be made on osteometric grounds (Woelfle 1967) and is not always conclusive.
148 Although the domesticated dove can only be distinguished from the wild rock dove by osteometric observations (Fick 1974), as the wild form does not naturally occur in our part of the world, the doves at Middelburg were probably of the domesticated variety.

${ }^{149}$ Scully 1995, 72, 77.

${ }^{150}$ Gadid: member of the Gadidae family (cod, haddock, whiting, etc.).

${ }^{151}$ Verkem et al. 2003, 333-48.

${ }^{152}$ Harper 1972.

${ }^{153}$ Data not presented here.

${ }^{154}$ The skeletal remains of songbirds are extremely difficult to identify as to species.

${ }^{155}$ Van Neer \& Ervynck 1994.

${ }^{156}$ Hoffmann 1994.

${ }^{157}$ The Clupeidae family include herring, sprat, and anchovy.

${ }^{158}$ See the Visboeck by Adriaen Coenen (1578) for a contemporary account of marine fishing, fish processing and fish trade (Egmond 1997).

${ }^{159}$ Van Vliet 2003.

160 cf. Ervynck 2004.

${ }^{161}$ See Ervynck et al. 2003 for a discussion of the definition of luxury within an archaeozoological context.

${ }^{162}$ Van Haaster 2003; Hall et al. 1990.

${ }^{163}$ Cooremans 1994; 2004; Belradar.

164 Sample 46h.

${ }^{165}$ Van Zeist \& Palfenier-Vegter 1979.

${ }_{166}$ Dodoens 1644, 824.

${ }^{167}$ Lindemans 1952, 102.

${ }_{168}$ Buurman 1993.

169 e.g. Cooremans 2000; van Haaster 2003; Luijten 1992; 1994; Kooistra et al. 1998.

170 Dodoens 1644.

${ }^{171}$ Lindemans 1952, 43.

172 Dodoens 1644; Lindemans 1952.

${ }^{173}$ Brinkkemper 1991.

${ }^{174}$ Dodoens 1644; Lindemans 1952.

${ }^{175}$ Lindemans 1952, 169.

${ }^{176}$ Kooistra et al. 1998.

177 e.g. Dodoens 1644.

${ }^{178}$ Radar Nederland; Belradar.

${ }^{179}$ Vanderhoeven et al. 1993.

${ }^{180}$ Unpublished data.

${ }^{181}$ Collet 1992.

182 Katzer 2004.

${ }^{183}$ Wiltshire 1995.

${ }^{184}$ Lindemans 1952.

${ }^{185}$ Lindemans 1952.

${ }^{186}$ Dodoens 1644.

${ }^{187}$ Lindemans 1952, 206.

${ }^{188}$ Van Haaster 1997a, 89.

189 Van Zeist et al. 2000.

${ }^{190}$ Lindemans 1952.

${ }^{191}$ Lindemans 1952, 123.

192 Brinkkemper 1991. 
193 Lindemans 1952, 269.

194 Dewilde 1983.

${ }^{195}$ Stieperaere \& Fransen 1982; Weeda et al. 1985-94;

Tamis et al. 2004.

${ }^{196}$ Schaminee et al. 1998.

${ }^{197}$ Weeda et al. 1988; 1991; 1994.

198 Deforce, below.

199 Knörzer 1984, 332.

${ }^{200}$ Luijten 1992; 1994; Moffett 1992; Cooremans 1994;

Kooistra et al. 1998; van Haaster 2003.

${ }^{201}$ Moore et al. 1991.

${ }^{202}$ Greig 1981, 279; 1994, 102.

${ }^{203}$ Pals 1997.

${ }^{204}$ Deforce 2004, 388; 2006; forthcoming; Van den Brink 1988, 116; 1989, 269; Van Haaster 1997b, 157.

${ }^{205}$ Van Haaster 1997b, 157, table 2; Deforce 2004, 388; forthcoming; Hänninen \& Van Haaster 1998, 4; Van den Brink 1988, 116; 1989, 269.

${ }^{206}$ Van Haaster 1997a.

${ }^{207}$ Harvey 1984, 92; Van Haaster 1997a, 67; Dodoens 1664, 978-9.

208 Van Haaster 1997b, 148.

${ }^{209}$ Greig 1981.

${ }^{210}$ Dalby 2000; Küster 2000.

211 Behre 1999.

212 Thienpont et al. 1979; Jones 1982.

213 Bouchet et al. 1991.

214 e.g. Grzywinski 1959; Greig 1981; Jones 1982; Bouchet et al. 1991; Bouchet 1994.

${ }^{215}$ Lambinon et al. 1998.

${ }^{216}$ Cronberg 1986; Komárek \& Jankovská 2001.

${ }^{217}$ Mitrovic 1997.

${ }^{218}$ Greig 1981; Deforce 2004; forthcoming.

${ }^{219}$ Deforce 2004; 2006; forthcoming; Van den Brink 1989.

220 Zoller 1981.

221 Nanson 2005.

${ }^{222}$ Casparie et al. 1995.

${ }^{223}$ Casparie et al. 1995.

${ }^{224}$ De Groote, A. 1999; Casparie et al. 1995.

${ }^{225}$ Gale \& Cutler 2000.

${ }^{226}$ Pieter Van Hecke, a veteran of Captain Boisset's company, encamped at Middelburg in 1605 testified that 'zag dat de soldaten koeien en andere beesten lieten grazen op de landen en dat de vijand de beesten kwam halen . . . koestallen werden door de soldaten voor hun eigen beesten gebruikt', Raad van Vlaanderen, BDL 448.

${ }^{227}$ Parker 2004, 207.

\section{BIBLIOGRAPHY}

Anon, P. (ed.) 2000, Archéologie du poêle en céramique du Haut Moyen Age à l'époque moderne: technologie, décors, aspects culturels, Revue Archéologique de l'Est, 15ième supplément.

Arts, N. 1992a, 'Bouwceramiek en andere elementen van het gebouw', in Arts 1992b, 101-9.
Arts, N. (ed.) 1992b, Het kasteel van Eindhoven: archeologie, ecologie en de geschiedenis van een heerlijke woning 1420-1676, Eindhoven: Museum Kempenland.

Arts, N. 1994, Sporen onder de Kempische stad, Eindhoven: Museum Kempenland.

Bartels, M. 1999, Steden in scherven / Cities in sherds. Vondsten uit beerputten in Deventer, Dordrecht, Nijmegen en Tiel (1250-1900), Zwolle: Rÿksdienst voor het Ouudheidkundig Bodemonderzoek.

Bauwens, A. (ed.) 1987, Opstand en verval: aspecten van het dagelijks leven tijdens de laatste decennia van de 16de eeuw, Bruges: Herrebaut.

Bauwens, A.R. \& De Vries, D. 2004, Oorlog in het Land van Cadzand in 2004: een stripverhaal van Floris Balthasar, Ijzendijke: Heemkundige Kring West-Zeeuws-Vlaanderen.

Behre, K.E. 1999, 'The history of beer additives in Europe - a review', Veget. Hist. Archaeobot. 8, $35-48$.

Berglund, B.E. 1986, Handbook of Holocene Palaeoecology and Palaeohydrology, Chichester: John Wiley.

Blake, H. et al. 2003, 'From popular devotion to resistance and revival in England: the cult of the Holy Name of Jesus and the Reformation', in Gaimster \& Gilchrist 2003, 176-202.

Blanquart, P. et al. 2001, Autour de la première enceinte, Archéologie à Bruxelles 4.

Boekwijt, H.W. \& Janssen, H.L. 1988, Kroniek van bouwhistorisch en archeologisch onderzoek's Hertogenbosch, 's Hertogenbosch: Kring Vrienden.

Boekwijt, H.W. \& Janssen, H.L. 1997, Bouwen en Wonen in de Schaduw van de Sint Jan. Kroniek Bouwhistorisch en Archeologisch Onderzoek 's Hertogenbosch 2, 's Hertogenbosch: Kring Vrienden.

Boessneck, J., Müller, H.-H. \& Teichert, M. 1964, 'Osteologische Unterscheidungsmerkmale zwischen Schaf (Ovis aries Linné) und Ziege (Capra hircus Linné)', Kühn-Archiv 78:1-2, 1-129.

Bouchet, F. 1994, 'Maladies parasitaires identifiées dans le remplissage d'une latrine à tonneau au village déserté de Walraversijde (ville d'Ostende, prov. De Flandre Occidentale)', in Pieters 1994, 234-6.

Bouchet, F., Ervynck, A. \& Ravenschot, P. 1991, 'Rijk, maar proper? Parasitologisch onderzoek van een put uit de Schepenhuisstraat', Stadsarcheologie 15, 8-14.

Brinkkemper, O. 1991, 'Wetland farming in the area to the south of the Meuse estuary during the Iron Age and Roman Period: an environmental and palaeo-economic reconstruction', Analecta Praehistorica Leidensia 24. 
Bungeneers, J. 1992, 'Een afvalput in het voormalige bisschoppelijke paleis', in Veeckman 1992, 1322.

Buurman, J. 1993, 'Verkoolde mout uit een laatmiddeleeuwse bierbrouwerij te Gramsbergen (Overijssel)', Westerheem 42:4, 179-84.

Caluwé, D. 2004, 'Glasvondsten', in Wouters 2004, 95-106.

Caluwé D. 2005a, 'Een glasensemble opgegraven in het Steen te Antwerpen: typologische en chronologische studie', BRABOM 6, 107-212.

Caluwé, D. 2005b, 'Archaeological vessel glass of the late medieval and early modern periods in the former Duchy of Brabant: an interdisciplinary approach', Annales du 16è Congrès de 'Association Internationale pour l'Histoire du Verre 219-52.

Caluwé, D. 2006, 'The use of drinking vessels in the context of dining and communal meals: some preliminary thoughts drawn on archaeological evidence from medieval and post-medieval periods in Flanders and the Duchy of Brabant (Belgium)', Food \& History 4:1, 279-304.

Casparie, W.A. et al. 1995, 'Vijftig houtsoorten in Groningen', in Helfrich et al. 1995, 38-43.

Chalmin-Sirot, E. 2001, 'Les modèles princiers et leur imitation dans le milieu seigneurial en territoire Genevois et Savoyard (XIVe-XVe siècles)', in Renoux 2001, 200-5.

Chambon, R. 1955, L'Histoire de la verrerie en Belgique du IIème siècle à nos jours, Brussels: Éditions de la Librairie Encyclopédique.

Clevis, H. \& Thijssen, J. 1989, Kessel, huisvuil uit een kasteel, Mededelingenblad Nederlandse Vereniging van Vrienden van de Ceramiek 136:4.

Collet, E. 1992, Specerijkelijk, de specerijenroutes, Brussels: Algemene Spaar- en Lijfrente Kas.

Cooremans, B. 1994, 'Het plantaardig materiaal', in Wouters et al. 1994, 344-8.

Cooremans, B. 2000, 'Het macrobotanisch onderzoek: een speurtocht naar plantaardige (voedsel) resten', in Veeckman et al. 2000, 131-9.

Cooremans, B. 2004, 'Macrobotanisch onderzoek', in De Groote et al. 2004, 377-86.

Courtney, P. 1993, 'The medieval and post-medieval objects', in Ellis 1993, 134-60.

Courtney, P. 2004, 'Small finds', in Rodwell \& Bell 2004, 365-96.

Cronberg, G. 1986, 'Blue-green algae, green algae and chrysophyceae in sediments', in Berglund 1986, 507-26.

Dalby, A. 2000, Dangerous Tastes: the Story of Spices, Berkeley: University of California Press.

Davis, O.K. 1994, Aspects of Archaeological Palynology: Methodology and Applications, Amer. Ass. Stratigr. Palyn., Contrib. Ser. 29.

De Clercq, W., Dumoulyn, J. \& Haemers, J., 2007, 'Vivre noblement: material and elite identity in late medieval Flanders', $J$. Interdisciplinary Hist., 38:1, 1-31.

De Clercq, W., Mortier, S. \& Pype, P. 2004, 'Archeologisch onderzoek in Middelburg-in-Vlaanderen: drie jaar opgravingen op het opper- en neerhof van het kasteel van Pieter Bladelin', Jaarboek Heemkundige kring het Ambacht Maldegem, 272-96.

De Clippelle-De Bleser, C. 1988, 'De Brugse glasvondsten', in De Witte 1988, 141-50.

De Groote, K. 1993, 'Het afval van de Rijke Klaren: noodonderzoek in de voormalige abdij van Beaulieu te Petegem (gem. Wortegem-Petegem, prov. Oost-Vlaanderen)', Archeologie in Vlaanderen 2, 335-412.

De Groote, K. et al. 2004, 'De Valcke, de Slotele en de Lelye, burgerwoningen op de Grote Markt te Aalst (prov. Oost-Vlaanderen): onderzoek naar de bewoners, analyse van een vroeg-16de eeuwse beerputvulling en de evolutie tot stadhuis', Archeologie in Vlaanderen 8, 281-408.

De Lettenhove, J.K. (ed.) 1844, Euvres de Chastellain 5, Brussels: Heussner.

De Witte, H. (ed.) 1988, Brugge onder-zocht: tien jaar stadsarcheologisch onderzoek, Bruges: Jempie Herrebout.

De Witte, H. (ed.) 1991, De Brugse Burg: van grafelijke verstreking tot moderne stadskern, Brugge: Die Keure.

Deforce, K. 2004, 'Palynologisch onderzoek', in De Groote et al. 2004, 386-90.

Deforce, K. 2006, 'The historical use of ladanum: palynological evidence from 15 th and 16 th century cesspits in northern Belgium', Veget. Hist. Archaeobot. 15, 145-148.

Degré, S. 1995, Brouwerijen in de Sint-Katelijnewijk, Archeologie in Brussel 2.

Denissen, S. 1982, 'De voorwerpen in glas', in Oost 1982, 113-81.

Denissen, S. 1984, 'De opgravingen aan de Kaasstraat 13, Afvalput 2 te Antwerpen, 3. Het Glas', Bulletin van de Antwerpse Vereniging voor Bodemen Grotonderzoek 1, 25-46.

Denissen, S. 1985, 'De glasvondsten uit de afvalputten van Huis 'Halmale', Venusstraat 18 a te Antwerpen', Bulletin van de Antwerpse Vereniging voor Bodem-en Grotonderzoek 6, 9-44.

Devliegher, L. 1990, 'Oude glasramen in Brugge', Biekorf 95, 103.

Dewilde, B. 1983, 20 Eeuwen vlas in Vlaanderen, Tielt: Lannoo.

Dodoens, R. 1644, Cruydtboeck, Antwerp: Balthasar Moretus.

Dreier, F.A. 1989, Venezianische Gläser und 'Façon de Venise', Berlin: Kunstgewerbemuseums.

Duysters, K. 2002, Facetten van glas: de glascollectie van het Historisch Museum Arnhem, Arnhem: Historisch Museum. 
Egan, G. (ed.) 1998, Medieval Finds from Excavations in London, 6. The Medieval Household, London: Museum of London.

Egan, G. 2005, Material Culture in London in an Age of Transition: Tudor and Stuart Period Finds c 1450-c 1700 from Excavations at Riverside Sites in Southwark, MoLAS Monogr. 19.

Egmond, F. 1997, Een bekende Scheveninger: Adriaen Coenen en zijn Visboeck van 1578, Den Haag: Centrum voor Familiegeschiedenis van Scheveningen.

Ellis, P. (ed.) 1993, Beeston Castle, Cheshire: Excavations 1968-85 by Laurence Keen and Peter Hough, Engl. Heritage Archaeol. Rep. 23.

Ervynck, A. (ed.) 1994, 'De Burcht' te Londerzeel: bewoningsgeschiedenis van een motte en een bakstenen kasteel, Archeologie in Vlaanderen Monografie $\mathbf{1}$.

Ervynck, A. 2003, 'De introductie van het konijn in de Lage Landen: een verkeerde datering voor vondsten uit een latrine bij de abtswoning van de Sint-Salvatorsabdij te Ename (stad Oudenaarde, prov. Oost-Vlaanderen)', Archeologie in Vlaanderen 7, 111-4.

Ervynck, A. 2004, 'Orant, pugnant, laborant: the diet of the three orders in the feudal society of medieval north-western Europe', in O'Day et al. 2004, 215-23.

Ervynck, A. \& Van Neer, W. 1993, 'Het dierlijk botmateriaal', in De Groote 1993, 390-403.

Ervynck, A., Van Neer, W. \& Van der Plaetsen, P. 1994, 'Dierlijke resten', in Ervynck 1994, 99-170.

Ervynck, A. et al. 2003, 'Beyond affluence: the zooarchaeology of luxury', World Archaeol. 34:3, 428-41.

Everaert, J. 2003a, 'Livinus Apollonius, Middelburgs humanist, verzeild op de Canarische eilanden', Jaarboek Heemkundige kring het Ambacht Maldegem 8, 279-93.

Everaert, J.G. 2003b, La inquisición revela: Levino Apolonio (1545-1595), preceptor canario o plagiario flamenco, <http://www.ceha-madeira.net/ canarias/hia34.html $>$ [accessed 6 July 2007].

Fick, O.K.W. 1974, Vergleichend morphologische Untersuchungen an Einzelknochen europäischer Taubenarten, Munich: Inaugural-Dissertation Universität München.

Fontaine, C. 2001, 'Les verres de la rue de Dinant, du XVIe au XVIIe siècle', in Blanquart et al. 2001, 226-45.

Fontaine, C. 2002, 'Verrerie vénitienne ou façon de Venise des XVIe et XVIIe siècles à Bruxelles: le témoignage archéologique', in Veeckman 2002, 415-20.

Fontaine, C. \& Degré, S. 1995, 'Het glas', in Degré 1995, 133-58.
Gaimster, D. 1997, German Stoneware 1200-1900: Archaeology and Cultural History, London: British Museum Press.

Gaimster, D. (ed.) 1999, Maiolica in the North, Brit. Mus. Occ. Pap. 122.

Gaimster, D. \& Gilchrist, R. (eds) 2003, The Archaeology of Reformation 1480-1580, Soc. Post-Medieval Archaeol. Monogr. 1.

Gaimster, D., Redknap, E. \& Wegner, H.-H. (eds) 1988, Zur Keramik des Mittelalters und der beginnende Neuzeit im Rheinland. Medieval and Later Pottery from the Rhineland and its Markets, Brit. Archaeol. Rep. Int. Ser. 440.

Gale, R. \& Cutler, D. 2000, Plants in Archaeology, Kew: Westbury \& Royal Botanic Gardens.

Gevaert, G. Pieters, M. \& Caluwé, D. (eds) 2003, Glas van vissers, kooplui, monniken en heren: middeleeuws en later glas uit het bodemarchief van Kust-Vlaanderen en Zeeland, Oostende: Museum Walraversijde.

Gilliodts-Van Severen, L. 1891, Coutumes des pays et comté de Flandre, quartier de Bruges: coutumes des petites villes et seigneuries enclavées $\mathbf{3}$, Brussels: Gobbaerts.

Greig, J. 1981, 'The investigation of a medieval barrel-latrine from Worcester', J. Archaeol. Sci. 8, 265-82.

Greig, J. 1994, 'Pollen analysis of latrine fills from archaeological sites in Britain: results and future potential', in Davis 1994, 101-14.

Groeneweg, G. 1987, 'Aardewerk uit de Bergse bodem: de spreeuwpot', Brabants Heem 39, 154-67.

Grzynski, L. 1959, 'Analysis of faeces from the Middle Age period', Zoologica Polonia 10, 195-9.

Guilhot, J.O. \& Munier, C. 1990, Besançon — Rue de Vignier, verreries des XIV-XVIèmes siècles, Revue archéologique de l'Est et du Centre-Est, 9ème supplémént, 149-72.

Gutiérrez, A. 2000, Mediterranean Pottery in Wessex Households (13th to 17th centuries), Brit. Archaeol. Rep. Brit. Ser. 306.

Hall, A.R. \& Kenward, H.K. 1982, 'Environmental archaeology in the urban context', Counc. Brit. Archaeol. Res. Rep. 43, 66-70.

Hall, A.R. \& Kenward, H.K. (eds) 1990, Environmental Evidence from the Colonia, The Archaeology of York 14:6.

Hall, A.R., Kenward, H.K. \& O’Connor, T.P. 1990, 'Discussion and synthesis', in Hall \& Kenward 1990, 385-419.

Hänninen, K. \& Van Haaster, H. 1998, Een 16e eeuwse beerput uit Oldenzaal — Stadhuis/ Ganzenmarkt met veel boekweit, BIAXiaal 69.

Harper, J. 1972, 'The tardy domestication of the duck', Agricult. Hist. 46:3, 385-9. 
Harvey, J. 1984, 'Vegetables in the Middle Ages', Gard. Hist. 12, 89-99.

Helfrich, K., Benders, J.F. \& Casparie, W.A. (eds) 1995, Handzaam hout uit Groninger grond: houtgebruik in de historische stad, Groningen: Stichting Monument en Materiaal.

Henkes, H.E. 1994, Glas zonder glans: vijf eeuwen gebruiksglas uit de bodem van de Lage Landen 1300-1800, Rotterdam Pap. 9.

Henkes, H.E. 2002, 'A 16th-century enamelled beaker with portrait busts excavated in the Netherlands', J. Glass Stud. 40, 186-94.

Heymans, H. 1989, Van put naar kluis: historisch, bouwhistorisch en archeologisch onderzoek van 'den Prince van Luyck' en 'De Stadt Amsterdam' te Maaseik, Maaseik: Museactron.

Hillewaert, B. \& Verhaeghe, F. 1991, 'Een afvalput uit de 16de-18de eeuw', in De Witte 1991, 207-49.

Hoffmann, R.C. 1994, 'Remains and verbal evidence of carp (Cyprinus carpio) in medieval Europe', in Van Neer 1994, 139-50.

Hupperetz, W. 2004, Het geheugen van een straat: achthonderd jaar wonen in de Visserststraat te Breda, Erfgoedstudie 2.

Hurst, J.G., Neal, D.S. \& Van Beuningen, H.J.E. 1986, Pottery Produced and Traded in North-west Europe 1350-1650, Rotterdam Pap. 6.

Jacobs, E. \& Graas, T.G.M. 1983, 'Glas', in Janssen 1983, 237-48.

Janse, H. 1971, Vensters, Nijmegen: Primavera Pers.

Janssen, H.L. (ed.) 1983, Van Bos tot Stad, opgravingen in 's Hertogenbosch, 's Hertogenbosch: Dienst Gemeentewerken.

Jones, A.K.G. 1982, 'Human parasite remains: prospects for a quantitative approach', in Hall \& Kenward 1982, 66-70.

Katzer, G. 2004, Katzer's Spice Pages, <http://www. uni-graz.at/ katzer $>$ [last modified 5 May 2004].

Killock D. \& Meddens, F. 2005, 'Pottery as plunder: a 17th-century maritime site in Limehouse London', Post-Medieval Archaeol. 39:1, 1-91.

Kiple, K. \& Ornelas, K.C. 2000, The Cambridge World History of Food, Cambridge: University Press.

Klesse, B. 1973, Kataloge des Kunstgewerbemuseums Köln, 1. Glas, Cologne: Kunstgewerbemuseums.

Klingelhöfer, E. 2005, 'Edmund Spenser at Kilcolman Castle: the archaeological evidence', PostMedieval Archaeol. 39:1, 133-54.

Knörzer, K.H. 1984, 'Aussagemöglichkeiten von paläoethnobotanischen Latrinenuntersuchungen', in Van Zeist \& Casparie 1984, 331-8.

Komárek, J. \& Jankovská, V. 2001, Review of the Green Algal Genus Pediastrum: Implication for Pollenanalytical Research, Bibliotheca Phycologica 108.
Kooistra, L. at al. 1998, Botanisch onderzoek aan beerputten, afvalkuilen en ophogingslagen van de steden Dordrecht en Nijmegen uit de 12de-20ste eeuw, BIAXiaal 52.

Küster, H. 2000, 'Trading in tastes: spices and flavourings', in Kiple \& Ornelas 2000, 431-7.

Lambinon, J. et al. 1998, Flora van België, het Groothertogdom Luxemburg, Noord-Frankrijk en de aangrenzende gebieden (Pteridofyten en Spermatofyten), Meise: Nationale Plantentuin van België.

Lettany, L., Ervynck, A. \& Veeckman, J. 1992, 'Sluikbegravingen en huishoudelijk afval: de opgravingen aan de Schoytestraat', in Veeckman 1992, 77-91.

Liefkes, R. 2002, 'Glass drinking bells à la façon d'Anvers', in Veeckman 2002, 429-34.

Lindemans, P. 1952, Geschiedenis van de landbouw in België, Antwerp: De Sikkel.

Luijten, H. 1992, 'Zaden en vruchten: overblijfselen van het plantaardig voedsel en de begroeiing van de grachten', in Arts 1992b, 237-44.

Luijten, H. 1994, 'Gebruiksplanten en de natuurlijke vegetatie van het Heuvelterrein', in Arts 1994, 302-12.

Marie, J. \& Schwien, J.-J. 2000, 'Le poêle en terre médiéval: réflexions sur sa structure et ses qualités calorifiques', in Anon 2000, 146-73.

Markgraf, F. (ed.) 1981, Gustav Hegi, Illustrierte Flora von Mittel-Europa 1:2, Berlin: Paul Parey.

Martens, M. 1997, 'Het kasteel van Middelburg', Jaarboek van de heemkundige kring Het Ambacht Maldegem 3, 179-89.

Martens, M. 2004, 'Middelburg tijdens de Tachtigjarige Oorlog (1568-1648), 1. Middelburg en de Reformatie (1564-1584)', Jaarboek van de heemkundige kring Het Ambacht Maldegem 10, 297-328.

Mitrovic, S. 1997, What Scum is That? Algal Blooms and Other Prolific Plant Growth, Parramatta (NSW): Department of Land \& Water Conservation, Centre for Natural Resources, Water Quality Services Unit.

Moffett, L. 1992, 'Fruits, vegetables, herbs and other plants from the latrine at Dudley Castle in central England, used by the Royalist garrison during the Civil War', Rev. Palaeobot. Palynol. 73, 271-86.

Moore, P.D., Webb, J.A. \& Collinson, M.E. 1991, Pollen Analysis, Oxford: Blackwell Science.

Moran, J. 2005, 'Glass', in Klingelhöfer 2005, 145.

Mosel, C. 1979, Sammlungskataloge des KestnerMuseums Hanover, 1:2. Glas MittelalterBiedermeier, new edn, Hanover: KestnerMuseums.

Musacchio, J.-M. 2000, 'The Madonna and Child, a host of saints, and domestic devotion in 
Renaissance Florence', in Neher \& Shepherd 2000, 147-64.

Nanson, A. 2005, 'Situation of the conservation of Norway spruce in Belgium', <http://www. ipgri.cgiar.org/networks/euforgen/Networks/ Conifers/Picea_abies/Country_reports/ pactyrepBEL.htm> [accessed 24 April 2006).

Neher, G. \& Shepherd, R. (eds) 2000, Revaluing Renaissance Art, Aldershot: Ashgate.

O'Day, S.J., Van Neer, W. \& Ervynck A. (eds) 2004, Behaviour Behind Bones: the Zooarchaeology of Ritual, Religion, Status and Identity, Oxford: Oxbow Books.

Offmann, C. \& Schneider, M. 2001, Von der Feuerstelle zum Kachelofen: Heizanlagen und Ofenkeramik vom Mittelalter bis zur Neuzeit, Stralsund: Kulturhistorisches Museum.

Oost, T. (ed.) 1982, Van Nederzetting tot Metropool: archeologisch-historisch onderzoek in de Antwerpse binnenstad, Antwerp: Stad Antwerpen.

Pals, J.P. 1997, 'De introductie van cultuurgewassen in de Romeinse Tijd', in Zeven 1997, 25-52.

Parker, G. 2004, The Army of Flanders and the Spanish Road 1567-1659, Cambridge: University Press.

Pieters, M. 1994, 'Een 15de-eeuwse sector van het verdwenen vissersdorp te Raversijde (stad Oostende, prov. West-Vlaanderen): interimverslag 1994', Archeologie in Vlaanderen 4, 219-36.

Pinchart, A. 1881-82, 'La fabrication de tapisserie de haute-lisse à Middelbourg en Flandre', Annales de la Société d'Émulation de Bruges 32, 388.

Reineking-Von Bock, G. 1971, Kataloge des Kunstgewerbemuseums Köln, 4. Steinzeug. Cologne: Kunstgewerbemuseums.

Renoux, R. (ed.) 2001, «Aux marches du palais»: Qu'est-ce-qu'un palais médiéval?, Le Mans: Université du Maine.

Rieb, J.P. 1972, 'Les verres du XVème au début du XIIème siècle à Strasbourg', Recherches archéologiques médiévales de la France de L'Est 1, $115-54$

Ring, E. (ed.) 2003, Glaskultur in Niedersachsen: Tafelgeschirr und Haushaltglas vom Mittelalter bis zur frühen Neuzeit, Archäologie und Bauforschung in Lüneburg 5.

Ritsema Van Eck, P.C. \& Zijlstra-Zweens, H.M. 1993-95, Glass in the Rijksmuseum 1-2, Zwolle: Waanders.

Roberts-Jones, P. \& Roberts-Jones, F. 1997, Pieter Bruegel De Oudere, Gent: Snoeck-Ducaju.

Rodwell, K. \& Bell, R. (eds) 2004, Acton Court: the Evolution of an Early Tudor Courtier's House, London: English Heritage.

Schaminée, J.H.J., Weeda, E.J. \& Westhoff, V. 1998, De vegetatie van Nederland, 4. Plantengemeenschappen van kust en binnenlandse pioniermilieus, Uppsala: Opulus Press.
Scully, T. 1995, The Art of Cookery in the Middle Ages, Woodbridge: Boydell Press.

Steppuhn, P. 2003, 'Glas als Kulturgut', in Ring 2003, 9-18.

Stieperaere, H. \& Fransen, K. 1982, Standaardlijst van de Belgische vaatplanten met aanduiding van hun zeldzaamheid en socio-ecologische groep, Dumortiera 22.

Swimberghe, P. 1983-84, 'Rijk huisraad gevonden in de Zilverstraat te Brugge in 1983', Jaarboek Stad Brugge Stedelijke Musea, 183-201.

Swinnen, M. 1989, 'Spreeuwenpotten: een heel verhaal...', Tijdschrift Mechelse Vereniging voor Archeologie 10:3, 41-7.

Tamis, W.L.M. et al. 2004, 'Standaardlijst van de Nederlandse flora 2003', Gorteria 30:4-5, 101-96.

Thienpont, D., Rochette, F. \& Vanparijs, O.F.J. 1979, Diagnose van verminose door koprologisch onderzoek, Beerse: Janssen Research Foundation.

Tyson, R. 2005, 'The glass', in Killock \& Meddens 2005, 52-8.

Van Damme, D. \& Ervynck, A. 1988, 'Medieval ferrets and rabbits in the castle of Laarne (East-Flanders, Belgium): a contribution to the history of a predator and its prey', Helinium 28:2, 278-84.

Van den Brink, W. 1988, 'Zaden en pollen uit een 16e eeuwse beerput uit de Postelstraat', in Boekwijt \& Janssen 1988, 113-24.

Van den Brink, W. 1989, 'Zaden en stuifmeel uit een put in 'Den Prince van Luyck", in Heymans 1989, 266-76.

Van der Linden, D. 1994, 'Rekenpenningen', in van Heeringen 1994, 37-40.

Van Eenhooge, D. 1999, 'Grafelijk afval: onderzoek van een beerput uit het Hof van Hoogstraten te Brussel', Archeologie in Vlaanderen 5, 263-302.

Van Gelder, E. \& Hoc, M. 1960, Les Monnaies des Pays-Bas bourguignons et espagnols (14341713), Amsterdam: J. Schulman.

Van Haaster, H. 1997a, 'De introductie van cultuurgewassen in de Nederlanden tijdens de Middeleeuwen', in Zeven 1997, 53-91.

Van Haaster, H. 1997b, 'Plantaardige en dierlijke resten uit de Middeleeuwen: de resultaten van het oecologisch onderzoek op het Sint Janskerkhof', in Boekwijt \& Janssen 1997, 140-62.

Van Heeringen, R. M. (ed.) 1994, Geld uit de belt, Vlissingen: Werkgroep Stadsarcheologie Vlissingen.

Van Neer, W. (ed.) 1994, Fish Exploitation in the Past, Annalen Zoölogische Wetenschappen 274.

Van Neer, W. \& Ervynck, A. 1994, L'Archéologie et le poisson, Ath: Instituut voor het Archeologisch Patrimonium.

Van Vliet, A.P. 2003, Vissers in oorlogstijd: de Zeeuwse zeevisserij in de jaren 1568-1648, 
Middelburg: Koninklijk Zeeuws Genootschap der Wetenschappen.

Van Vooren, G.A.C. 1987, 'Middelburg-inVlaanderen tijdens de Woelige jaren 1578-1583', in Bauwens 1987, 187-223.

Van Zeist, W. \& Casparie, W.A. 1984, Plants and Ancient Man: Studies in Palaeoethnobotany, Rotterdam: Balkema.

Van Zeist, W. \& Palfenier-Vegter, R.M. 1979, 'Agriculture in medieval Gasselte', Palaeohistoria 21, 268-99.

Van Zeist, W. et al. 2000, Cultivated and Wild Plants in Late- and Post-medieval Groningen: a Study of Archaeological Plant Remains, Groningen.

Vandenbulcke, V. \& Groeneweg, G. 1988, 'The stoneware stock of Jan-Peterss and Cornelis de Kanneman: two merchants of Rhenish pottery at Bergen-op-Zoom during the 2nd quarter of the 16th century', in Gaimster et al. 1988, 343-57.

Vanderhoeven, A., Vynckier, G. \& Vynckier, P. 1993, 'Het oudheidkundig bodemonderzoek aan de Veemarkt te Tongeren. Eindverslag 1988', Archeologie in Vlaanderen 3, 127-205.

Veeckman, J. (ed.) 1992, Blik in de bodem: recent stadsarcheologisch onderzoek in Antwerpen, Antwerp: Stad Antwerpen.

Veeckman, J. 1999, 'Maiolica in sixteenth- and early seventeenth-century Antwerp: the archaeological evidence', in Gaimster 1999, 113-24.

Veeckman, J. (ed.) 2002, Maiolica and Glass from Italy to Antwerp and Beyond: the Transfer of Technology in the 16th-early 17th Century, Antwerp: Stad Antwerpen.

Veeckman, J. \& Dumortier, C. 1999, 'De voorwerpen in majolica uit een afvalput in het Steen te Antwerpen', BRABOM 3, 135-92.

Veeckman, J. et al. 1992, 'De materïele leefwereld van onze voorouders: opgravingen aan de Zwartzustersstraat', in Veeckman 1992, 31-47.

Veeckman, J. et al. 2000, 'De inhoud van de afvalput van de Groote Schalien Loove: speuren naar de 17 de-eeuwse bewoners', BRABOM 4, 115-90.

Velde, B. 2002, 'Sixteenth and seventeenth-century drinking glasses in France: composition, shapes and geographic distribution', in Veeckman 2002, 201-14.

Verhaeghe, F. 1997, 'Middeleeuwse keramiek in Vlaanderen: productie en consumptie', Vlaanderen 46:3, 13-29.

Verkem, S. et al. 2003, Zoogdieren in Vlaanderen: ecologie en verspreiding van 1987 tot 2002, Mechelen: Natuurpunt Studie \& JNMZoogdierenwerkgroep.

Verschelde, K. 1867, Geschiedenis van Middelburg in Vlaenderen, Bruges.
Von Saldern, A. 1965, German Enamelled Glass, Corning: Museum of Glass.

Weeda, E.J. et al. 1985-94, Nederlandse ecologische flora: wilde planten en hun relaties 1-5, Hilversum: IVN.

Willemsen, A. 1998, Kinder delijt: middeleeuws speelgoed in de Nederlanden, Nijmeegse Kunsthistorische Stud. 6.

Willmott, H. 2002, Early Post-medieval Vessel Glass in England c. 1500-1670, Counc. Brit. Archaeol. Res. Rep. 132.

Wiltshire, P.E.J. 1995, 'The effects of food processing on the palatability of wild fruits with high tannin content', Res Archaeobotanicae 9, 385-97.

Woelfle, E. 1967, Vergleichend morphologische Untersuchungen an Einzelknochen des postcranialen Skelettes in Mitteleuropa vorkommender Enten, Halbgänse und Säger, Munich: Universität Inaugural-Dissertation.

Wouters, M. (ed.) 2004, Begraven (te) minderbreurs: het minderbroedersklooster van Diest archeologisch onderzocht, Brussels: Vlaams Instituut voor het Onroerend Erfgoed.

Wouters, W. et al. 1994, 'Een postmiddeleeuwse beerput aan de Hasseltse Poort te Tongeren (prov. Limburg)', Archeologie in Vlaanderen 4, 323-63.

Zeven, A.C. 1997, De introductie van onze cultuurgewassen en hun begeleiders, van het Neolithicum tot $1500 A D$, Wageningen: Vereniging voor landbouwgeschiedenis.

Zoller, H. 1981, 'Picea abies', in Markgraf 1981, $47-62$.

\section{UNPUBLISHED SOURCES}

Belradar, 'Macrobotanical Database'.

Caluwé, D. 2000, 'Het holglas uit een afvalkuil in het Antwerpse Steen', Free University of Brussels report.

Caluwé, D. 2005c, 'Het glas uit het kasteel van Middelburg, Voorlopig rapport van het glas uit de campagnes in 2002 en 2003', Free University of Brussels report.

Caluwé, D. forthcoming a, 'Een gelaesbert en een maendecken gelaesen: glas en gebruiksglas in $16 \mathrm{de}$ en $17 \mathrm{de}$-eeuwse boedels, aspecten van een materiële cultuur', Annales du 17e Congrès de l'Association Internationale pour l'Histoire du Verre 2006.

Caluwé, D. forthcoming b, 'Luxe gebruiksglas uit een beerput in de Catharinastraat te Breda', Stadsarcheologische Dienst Breda.

Caluwé, D. forthcoming c, 'Laat-middeleeuwse en vroeg-modern gebruiksglas vondsten te 's Hertogenbosch', Stadsarcheologische Dienst 's Hertogenbosch. 
Caluwé, D. forthcoming d, 'Middeleeuws en later glas in het hertogdom Brabant: aspecten van consumptie en productie', Free University of Brussels PhD thesis.

Caluwé, D. forthcoming e, 'Les coupes en verre opaline, des objets d'usage bien précis?' in La cuisine et la table dans la France de la fin du Moyen Age: contenus et contenants du XIVe au XVIe siècle.

De Groote, A. 1999, 'Archeobotanie van de middeleeuwse site Walraversijde (West-Vlaanderen, België): houtidentificatie en dendrochronologie', University of Ghent dissertation.

De Groote, K. 2005, 'Het aardewerk in de regio Oudenaarde in de Volle en Late Middeleeuwen (10de16de eeuw): technische en typologische analyse, chronologie, evolutie en betekenissen', Free University of Brussels PhD thesis.

Deforce, K., forthcoming, 'Het palynologisch onderzoek van de beerputten', in Pieters forthcoming.

Pieters, M. forthcoming, 'Een laatmiddeleeuws landelijk vissersmilieu in het zuidelijk Noordzeegebied, Raversijde (Oostende, België) 1992-2002: opgravingsverslag van 10 jaar opgravingen Vlaams', Brussels: Instituut voor het Onroerend Erfgoed.

Raad Van Vlaanderen, BDL 448 (4446) enqueesten September 1632 .

Radar Nederland, 'Macrobotanical Database'.
Van Haaster, H. 2003, 'Archaeobotanica uit's Hertogenbosch: milieuomstandigheden, bewoningsgeschiedenis en economische ontwikkeling in en rond een (post)middeleeuwse groeistad', Free University Amsterdam PhD thesis.

Wouters, H. 2001, 'Brabants vlakglas in de 16e en $17 \mathrm{e}$ eeuw: een historische, iconografische, archeologische en chemische benadering', Antwerp High School masters thesis.

Wouters, H. forthcoming, 'Een blik op het kasteel van Middelburg in Vlaanderen, een studie van de raamopeningen en -dichtingen op basis van het archeologische materiaal: glas, lood en natuursteen', Free University of Brussels masters thesis.

\section{ABBREVIATIONS}

BDL Bundel

BRABOM Berichten en Rapporten over het Antwerps Bodemonderzoek en Monumentenzorg

FHI Flemish Heritage Institute

IVN Instituut voor Natuurwetenschappen

MNV Minimum number of vessels

MoLAS Museum of London Archaeology Service

RBINSc Royal Belgian Institute for Natural Sciences

\section{Department of Archaeology and Ancient History of Europe, University of Ghent, Blandijnberg 2, B-9000 Ghent [w.declercq@ugent.be]}

Department of Art History and Archaeology, Free University of Brussels, Pleinlaan 2, 1050 Brussels (DC)

Flemish Heritage Institute, Koning Albert II-laan 19 bus 5, B-1210 Brussels (BC)

Flemish Heritage Institute, Doornveld 1 bus 30, B-1731 Asse-Zellik (FDB)

Flemish Heritage Institute, Wallestraat 167, B-9700 Oudenaarde-Ename (KDG)

Flemish Heritage Institute, Koning Albert II-laan 19 bus 5, B-1210 Brussels (KD, AE, AL)

The Monuments and Sites Division of the Flemish Government, Koning Albert II-laan, 19 bus 3, B-1210 Brussels (SM)

Municipality of Maldegem, Sint-Salvatorstraat 9, B-9700 Oudenaarde-Ename (PP)

Maria Van Bourgondiëlaan 32, B-8000 Bruges (SVB)

IUAP 06/22, Royal Belgian Institute for Natural Sciences, Vautierstraat 29, B-1000 Brussels \& Laboratory for Comparative Anatomy and Biodiversity, Catholic University of Leuven, Ch. Deberiotstraat 32, B-3000 Leuven $(W V N)$

Borsbeekstraat 98, B-2140 Antwerp (HW) 